\title{
The Octocoral Fishery in the Southeastern U.S. and Gulf of Mexico
}

\author{
MARK CHIAPPONE, PAOLA ESPITIA, LEANNE M. RUTTEN, and STEVEN L. MILLER
}

\section{Introduction}

The marine aquarium hobby has witnessed a resurgence in popularity within the United States since the 2007-09 recession (Bricker et al. ${ }^{1}$ ),

\begin{abstract}
${ }^{1}$ Bricker J. B., Bucks, A. Kennickell, T. Mach, and K. Moore. 2011. Surveying the aftermath of the storm: changes in family finances from 2007 to 2009. Working paper 2011-17, Mar. 2011, Fed. Reserve Bd., Finance and Econ. Discussion Ser., 38 p. (Online at https://www.federalreserve. gov/pubs/feds/2011/201117/201117pap.pdf).
\end{abstract}

The authors are with the Halmos College of Natural Science and Oceanography, Nova Southeastern University, 8000 N. Ocean Drive, Dania Beach, FL 33004. Corresponding author is Mark Chiappone (email: mc191@nova.edu).

doi: https://doi.org/10.7755/MFR.80.3.2

ABSTRACT-Octocorals, also known as gorgonians and soft corals, were previously managed by the U.S. South Atlantic (SAFMC) and Gulf of Mexico (GMFMC) Fishery Management Councils through a joint Coral Fishery Management Plan (FMP). Because octocorals are mostly collected from Florida waters, the Florida Fish and Wildlife Conservation Commission (FWC) is currently tasked with managing octocoral collection, including the monitoring of colony landings, in the Economic Exclusive Zone (EEZ) adjacent to Florida. Collection of 70,000 colonies per year total, which applies to both state and EEZ waters off Florida, is permitted under Rule 68B42.006 of the Florida Administrative Code, but has never been exceeded according to available landings data. Before octocoral management responsibility was transferred to the State of Florida, the SAFMC was concerned that octocoral landings data, as opposed to population data, were being used to set Acceptable Biological Catch limits and Overfishing limits under the new Federal fishery management standards. An additional concern with the octocoral fishery and other organisms captured for the marine aquarium and ornamental fisheries is that large taxonomic groups are lumped together, including species with potentially different life histories and ecological functions. with $\sim 1.8$ million households owning a saltwater aquarium (American Pet Products Association, 2014). Within the United States, Florida represents the largest component of the ornamental fishery, supplying live marine life to the aquarium industry with over 9 million individual animals per year, encompassing over 600 fish, invertebrate, and plant species (Rhyne et al., 2009). Management of this multispecies fishery is under the authority of the Federal Gulf of Mexico Fishery Management Council, the South Atlantic Fishery Management Council in EEZ waters off North Carolina, South Carolina, and Georgia, and the State of Florida's Fish and Wildlife

This study assessed some of the characteristics of the octocoral fishery by evaluating FWC Trip Ticket data, conducting interviews with octocoral collectors, and analyzing octocoral life history information and available fishery-independent data on population densities and sizes. Based on interviews with collectors, a synthesis of trip ticket results, and population abundance estimates, the long-term stability of the octocoral fishery is not likely to change significantly. The social dynamics of the aquarium industry to seek colorful, rare, and exotic marine species for home aquaria places octocorals at the lower end of the list of desired species. Octocoral distribution and abundance information obtained from an extensive search of the literature, along with available age, growth, and habitat data, suggests that current information is comprehensive and definitive, such that stock assessment or population $d y$ namic modeling could be considered but are probably not required to assess the status of collected octocoral species. For multiple sampling periods, over a decadal period (1999-09) in the Florida Keys, where most octocoral collection occurs, abundance estimates presented for 15 species illustrate that population sizes are large (tens of millions to hundreds of millions of colonies, per species) and abundance is stable or increasing. For example, the numbers of colonies
Conservation Commission (FWC) in Florida. Regulation of the collection of live tropical, ornamental, and marine species in Florida is governed by Rule Chapter 68B-42 of the Florida Administrative Code (FAC). The Florida regulations went into effect in 1991 and have undergone several revisions, affecting bag limits, proper collection techniques, reporting requirements, and area restrictions (and more) for recreational and commercial marine life collectors (Larkin et al., 2001). With a Saltwater Products License, commercial collectors can exceed the daily recreational bag limits that differ by species group. To collect and sell tropical fish and invertebrate species

collected in the Florida Keys in two of the collector categories represented $<0.004 \%$ of the estimated population sizes. The collectors and aquarium hobbyists interviewed stated that they would welcome and use a field guide to help with octocoral identification, which would ultimately provide better fishery-dependent taxonomic resolution for collected species. The collection of octocorals below the State of Florida quota of 70,000 colonies per year threshold, which has yet to be reached according to landings data, likely does not adversely affect the octocoral populations targeted. This conclusion is based upon the large population estimates determined for octocorals relative to the small number of colonies collected. This conclusion assumes that the distribution and population sizes of targeted species will continue to be relatively stable or increase. Information collected by the State of Florida through trip tickets is probably adequate to understand and manage the octocoral fishery. Minor reporting clarifications and better taxonomic resolution in reporting would help improve the accuracy of collecting data, but improved accuracy is not required to assess the current state of the fishery - the octocoral fishery is sustainable and would likely remain sustainable at colony collection levels orders of magnitude larger. 
such as mollusks, plants, live rock, and live sand, a Restricted Species endorsement and Marine Life endorsement are both required.

The State of Florida has collected commercial landings and effort data since November 1984, maintained in their Marine Fisheries Information System, commonly referred to as "Trip Ticket" data (Larkin et al., 2001). State of Florida landings data on marine life collection date back to 1994. The Florida Marine Life Association (FMLA), the official industry organization for marine life collectors, petitioned the Florida Marine Fisheries Commission in 1988 to adopt standards for the collection of tropical marine life species. Catch regulations were adopted as a result and the collection of marine life and tropical ornamental data were included in the Trip Ticket reporting system beginning in 1994. Originally designed to track the sales of seafood products from Florida waters, the Trip Ticket reporting program requires wholesale dealers to report information about saltwater products purchased (Section 379.362, Florida Statutes, and 68E5.002, FAC).

Subsequent concerns over the number of new Marine Life (ML) endorsement holders in the industry prompted the FMLA to petition the FWC to limit the entry of new marine life collectors (Division of Marine Fisheries, 2002, cited in Larkin et al., 2001), although an assessment of past and current trends about possible exploitation of individual species had not been conducted (Larkin et al., 2001). As a result, the State of Florida passed Senate Bill 1506 in 1998, which imposed a 4-yr moratorium on the issue of new ML endorsements (Florida Statute 370.06(2)(d)(2)). Further restrictions were introduced in 2005 for those wanting to collect or sell marine life species. In addition to a Saltwater Products License and a Restricted Species endorsement, collectors needed to apply and qualify for a ML endorsement. The endorsements are Marine Life Transferable Dive (MLD), Marine Life Non-trans- ferable Dive (MLN), and Marine Life Bycatch (MLB). To qualify for these endorsements, collectors had to show proof of commercial marine life landings and sales above a $\$ 5,000$ threshold between the licensing years of 1999 and 2003 (FAC 68B-42.0065). This process eliminated the part-time collectors and brought the number of active ML endorsement holders in the State of Florida down from 743 to 168 (Adams et al., 2001). About $10 \%$ of all ML endorsements are currently MLN (M. Bademan, FWC, personal commun.). Collectors wishing to obtain an ML endorsement may now only do so through the transfer of a pre-existing endorsement, since no new endorsements are currently being issued.

\section{Management and Regulation of the Fishery}

Octocorals were managed in the U.S. South Atlantic (North Carolina to Florida) and U.S. Gulf of Mexico (Florida to Texas) from 1990-2011 under the joint Gulf of Mexico and South Atlantic Coral Fishery Management Plan (FMP). Restructuring of the Coral FMP in 2011 (Amendment 7) subsequently excluded the management of octocorals in Federal waters off Florida, thereby transferring management responsibility to the State of Florida (FAC 68B-42.009). Octocorals are defined by the State of Florida as "any erect, non-encrusting species of the Subclass Octocorallia, except the species Gorgonia flabellum and $G$. ventalina" (FAC 68B-42.002). Recreational collectors may collect up to six octocoral colonies/day with a Florida Recreational Saltwater Fishing License (FAC 68B-42.005). There are no trip or daily collection limits on commercial landings; however, the annual quota for octocorals collected in State of Florida and adjacent Federal waters is currently 70,000 colonies (FAC 68B-42.006). Area restrictions on octocoral collection exist in Atlantic Federal waters north of Cape Canaveral, Biscayne National Park, and in the Stetson-Miami Terrace Deep Water Coral Habitat Area of Particular Concern, as well as the Pourtales-Terrace
Deep Water Habitat Area of Particular Concern adjacent to Florida waters (FAC 68B-42.0036).

During collection, no power tools may be used and only one inch of substrate around the perimeter of the base of the octocoral holdfast may be removed (FAC 68B-42.007 and 68B42.008). Octocorals must be collected alive and stored in a re-circulating live well or oxygenated system aboard the collection vessel (FAC 68B-42.0035). There are additional area closures for marine life collection in southeastern Florida, including National Parks (Everglades, Biscayne, Dry Tortugas), John Pennekamp Coral Reef State Park, and portions of the Florida Keys National Marine Sanctuary, including the Key Largo Management Area (formerly Key Largo National Marine Sanctuary), the Looe Key Management Area (formerly Looe Key National Marine Sanctuary), and various smaller no-take zones including Sanctuary Preservation Areas, Special-Use/ Research-Only Areas, and Ecological Reserves (15 CFR 922 Subpart P).

\section{Collector and Fishery Characteristics}

\section{Collector Demographics}

Of the $168 \mathrm{ML}$ tiered endorsement holders in Florida in 2013, only 64 reported octocorals landings. ${ }^{2}$ After consulting two marine life collectors familiar with the fishery, 53 octocoral collectors were identified as active collectors based in the Florida Keys ( $n=30$ collectors), the Florida east coast $(n=14)$, and the Florida west coast $(n=9)$. A letter that described the goals of this study with a request for additional information about the octocoral fishery was sent to the 53 active collectors. A second (and in some cases a third) request for information was sent via email to collectors $(n=30)$. Telephone and in-person interviews were conducted with 15 collectors, including 8 from the Florida Keys, 5 from the Florida east coast, and 2 from

\footnotetext{
${ }^{2}$ Florida Fish and Wildlife Conservation Commission, Tallahasse, Florida. Unpubl. data, Nov. 2014.
} 
the Florida west coast. Interview questions addressed the fishery (i.e., species collected, colony size, collection sites, and collection frequency), collection methods (i.e., collection techniques, holding facility set-up, and shipping logistics), and social issues within the fishery (i.e., purpose for starting a business, amount of time spent collecting, and collector etiquette). Information gathered from interviews and field visits to the Florida Keys (5 collectors visited) and Miami ( 2 collectors visited) was used to summarize octocoral fishermen and fishery characteristics.

In the State of Florida, octocoral collectors are required to hold a Saltwater Products License, Restricted Species endorsement, and a ML tiered endorsement (MLD, MLN, or MLB). These endorsements were either purchased before the moratorium on the issue of new ML endorsements in 2005 , or they were purchased from an existing license holder, typically as a package including the entire business (e.g., boat, warehouse, holding tanks, and collection sites). This is an expensive purchase considering the cost $(\sim 35,000$ US) of the ML endorsement. ${ }^{3}$ Many $(n=11)$ of the collectors interviewed are lifelong ocean and aquarium enthusiasts who have been diving since the 1960s and 1970s; thus, they have extensive experience to know where to efficiently find their target organisms. Other collectors $(n=4)$ learned the trade through an apprenticeship of sorts, helping a current ML holder while learning proper collection techniques. Over half (58\%) of the octocoral collectors contacted live in the Florida Keys (Monroe County), with the remaining residing on either the Florida east coast $(22 \%)$ or west coast $(20 \%)$. While octocorals are collected throughout Florida waters, $80 \%$ of reported landings come from Atlantic waters ${ }^{2}$, with the majority of the collection effort focused on Florida Keys shallow-water species.

\footnotetext{
${ }^{3}$ Anonymous marine life collectors interviewed in southeastern Florida, Personal commun., 2013-14.
}

\begin{tabular}{lll}
\multicolumn{2}{l}{ Table 1.-Octocorals typically collected in the Atlantic Ocean off Florida (H. Feddern, personal communication). } \\
\hline Species group & \multicolumn{1}{c}{ Scientific name } & Collector common name \\
\hline Other & Diodogorgia nodulifera & yellow finger/colorful sea rod gorgonian \\
& Eunicea sp. & brown tree gorgonian \\
& Muricea sp. & silver gorgonian \\
& Plexaurella nutans & large polyp gorgonian \\
& Pterogorgia citrina & yellow ribbon gorgonian \\
Purple & Antillogorgia sp. & purple plume gorgonian \\
& Antillogorgia sp. & purple willow gorgonian \\
& Antillogorgia elisabethae & purple frilly gorgonian \\
& Muriceopsis flavida & purple brush gorgonian \\
& Pterogorgia anceps & purple ribbon gorgonian \\
Red & Diodogorgia nodulifera & red finger gorgonian \\
& Swiftia exserta & orange tree gorgonian
\end{tabular}

Octocorals are mainly collected for the aquarium trade and not for the curio trade. A few opportunistic ML endorsement holders hold a MLB endorsement, which allows them to keep whole octocorals that are incidentally caught by shrimp nets. Since the quality of specimens obtained from bycatch is typically not suitable for the marine life trade due to tissue damage and broken branches, such colonies are dried and sold for the curio trade. ${ }^{3}$ Because shallow-water octocorals are found in great abundance throughout hard-bottom and coral reef habitats of south Florida, these fauna are typically easy to find and can be collected year-round. In contrast, because deeper water ( $>30 \mathrm{~m}$ depth) species such as Diodogorgia nodulifera, Swiftia exserta, and Leptogorgia spp. are more challenging to collect because of strong currents and the constraints of deeper diving, only a few of the collectors interviewed target deeper water (>30 m) species.

Despite the general ease in finding octocorals, no ML endorsement holders collect and sell octocorals exclusively. In a few cases $(n=3)$, octocorals represent nearly $50 \%$ of total marine life sales for collectors; however, more commonly $(n=12)$ octocorals comprise $20 \%$ or less of total marine life sales. The fishery is demand-driven, which means that octocorals are primarily collected upon request from wholesalers, retail stores, public aquariums, and aquarium hobbyists. The demand for octocorals within the aquarium industry has never been sufficient to support a business focused exclusively on octocoral collection. As a result, marine life collectors spread their efforts across collecting and selling marine fishes and a variety of invertebrates such as crabs, corallimorpharians, anemones, and snails. Table 1 lists the octocorals commonly collected for the aquarium trade in Florida (Feddern ${ }^{4}$ ) and Table 2 is an expanded list of species that was provided by marine life collectors interviewed and by FWC.

\section{Collection Methods}

Aquarium owners generally prefer clean, brightly colored purple, red, or yellow octocoral specimens that are heavily branched with large polyps in good condition (e.g., no visible signs of tissue loss or bleaching). Size matters, with specimens usually small enough to fit comfortably in home aquariums ( $<20 \mathrm{~cm}$ in height). Octocorals are collected using snorkeling, SCUBA, or hookah diving rigs. A hammer and chisel or dive knife is typically used to remove whole colonies (Fig. 1). As per FAC 68B-42.007, the holdfast and substrate with a maximum diameter 1 -in or less can be removed along with the colony. Some of the collectors interviewed believe that preserving the substrate with the holdfast increases the survivorship of a colony, but no formal studies have been conducted to test this observation.

Octocorals collected off the west coast of Florida, such as Leptogorgia spp., are often removed by hand from nearshore artificial reefs and bridge

${ }^{4}$ Feddern, Henry. Marine life collector, Florida Keys. Personal commun., Oct., 2013. 


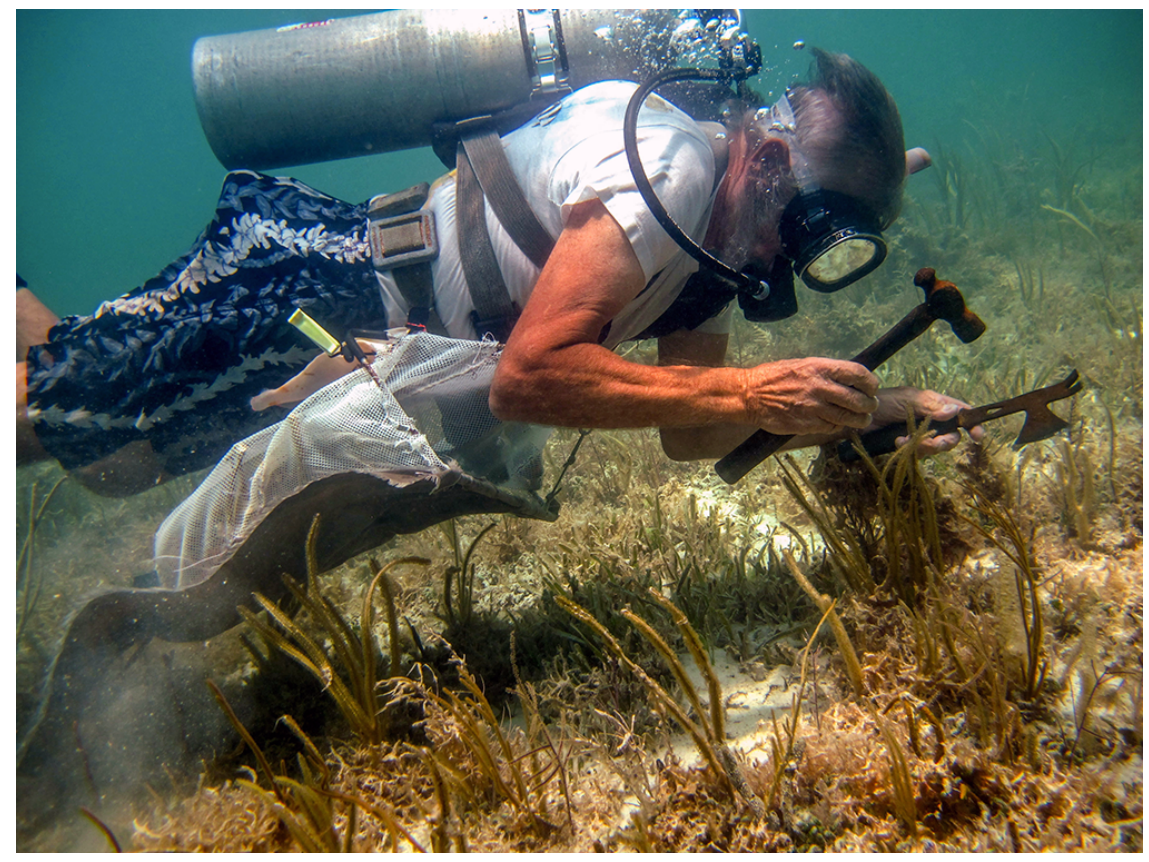

Figure 1.- Octocoral collector, Dr. H. Feddern, using a hammer and chisel to remove octocoral colonies to be sold in the aquarium trade.

Table 2.-Octocorals collected in the Atlantic Ocean and the Gulf of Mexico off Florida based upon personal communications with Florida collectors during 2013-14. Asterisk $\left(^{*}\right)$ indicate the most highly demanded octocoral taxa.

\begin{tabular}{|c|c|c|c|}
\hline $\begin{array}{l}\text { Species } \\
\text { group }\end{array}$ & Scientific name & Collector common name(s) & $\begin{array}{l}\text { Collection } \\
\text { location }\end{array}$ \\
\hline Other & $\begin{array}{l}\text { Antillogorgia acerosa } \\
\text { Diodogorgia nodulifera* } \\
\text { Muricea sp.* } \\
\text { Muricea elongata } \\
\text { Muricea muricata } \\
\text { Muricea pinnata } \\
\text { Plexaura homomalla } \\
\text { Plexaurella fusifera } \\
\text { Plexaurella nutans* } \\
\text { Pterogorgia citrina* }\end{array}$ & $\begin{array}{l}\text { golden plume gorgonian } \\
\text { yellow finger/colorful sea rod gorgonian } \\
\text { delicate spiny sea rod } \\
\text { orange spiny sea rod/rusty gorgonian } \\
\text { spiny sea fan } \\
\text { long spiny sea fan/silver gorgonian } \\
\text { black sea rod } \\
\text { brown tree gorgonian } \\
\text { giant slit pore/large polyp gorgonian } \\
\text { yellow ribbon/yellow sea whip gorgonian }\end{array}$ & $\begin{array}{l}\text { Atlantic } \\
\text { Atlantic } \\
\text { Atlantic } \\
\text { Atlantic } \\
\text { Atlantic } \\
\text { Atlantic } \\
\text { Atlantic } \\
\text { Atlantic } \\
\text { Atlantic } \\
\text { Atlantic }\end{array}$ \\
\hline Purple & $\begin{array}{l}\text { Antillogorgia spp. } \\
\text { Antillogorgia acerosa* } \\
\text { Antillogorgia elisabethae* } \\
\text { Antillogorgia kallos* } \\
\text { Briareum asbestinum* } \\
\text { Eunicea spp. } \\
\text { Eunicea flexuosa* } \\
\text { Muriceopsis flavida* } \\
\text { Pseudoplexaura sp. } \\
\text { Pseudoplexaura porosa } \\
\text { Pterogorgia anceps* } \\
\text { Pterogorgia guadalupensis }\end{array}$ & $\begin{array}{l}\text { purple frilly/purple whip gorgonian } \\
\text { Purple or golden willow gorgonian } \\
\text { purple frilly gorgonian } \\
\text { purple plume/bi-pinnate gorgonian } \\
\text { corky sea finger/sea stalk gorgonian } \\
\text { purple knobby/knobby sea rod/warty sea rod gorgonian } \\
\text { purple candelabra/swollen knob candelabrum gorgonian } \\
\text { purple brush/bottle brush gorgonian } \\
\text { porous sea rod } \\
\text { purple tree gorgonian } \\
\text { purple ribbon/angular sea whip gorgonian } \\
\text { purple blade/flat-blade/grooved-blade sea whip gorgonian }\end{array}$ & $\begin{array}{l}\text { Atlantic, Gulf } \\
\text { Atlantic } \\
\text { Atlantic } \\
\text { Atlantic } \\
\text { Atlantic } \\
\text { Atlantic } \\
\text { Atlantic } \\
\text { Atlantic } \\
\text { Atlantic } \\
\text { Atlantic } \\
\text { Atlantic, Gulf } \\
\text { Gulf }\end{array}$ \\
\hline Red & $\begin{array}{l}\text { Diodogorgia nodulifera* } \\
\text { Ellisella barbadensis } \\
\text { Icilliogorgia schrammi } \\
\text { Leptogorgia punicea } \\
\text { Leptogorgia virgulata } \\
\text { Nicella schmitti } \\
\text { Swiftia exserta* }\end{array}$ & $\begin{array}{l}\text { red finger/colorful sea rod gorgonian } \\
\text { Devil's sea whip } \\
\text { orange deep-water fan } \\
\text { sea whip/carmine sea spray gorgonian } \\
\text { sea whip gorgonian } \\
\text { red/bushy sea whip } \\
\text { orange tree/red polyp gorgonian }\end{array}$ & $\begin{array}{c}\text { Atlantic } \\
\text { Atlantic } \\
\text { Atlantic } \\
\text { Atlantic, Gulf } \\
\text { Gulf } \\
\text { Atlantic } \\
\text { Atlantic }\end{array}$ \\
\hline
\end{tabular}

pilings. This is similar in the Florida Keys; however, both locations also involve substantial collection directly from the natural seabed. Collected colonies are placed in mesh bags or plastic collection containers during the dive, and then stored in covered species-specific live wells or 5-gallon buckets with air stones during transport to a holding facility. Water changes are done throughout the day ( $\mathrm{P}$. Espitia, personal observ.). Collectors usually fulfill octocoral orders within an hour, so the remainder of the day is spent collecting other marine species. Collectors with wholesale orders noted that they collect as many as 600 octocorals per month, and then distribute several large orders to wholesalers. Collection sites are species-specific and several types of marine life (e.g., emerald crabs, Mithraculus sculptus) may be targeted along with octocorals at a single site. All of the collectors interviewed specified that they have multiple sites from which colonies are removed and that they are conscious to rotate sites to reduce collecting stress on individual site locations. Although collectors do not officially share their work site locations with each other, they generally avoid one another. Some Florida Keys marine life collectors noted that in the past they were followed by other collectors who would try and learn where they were collecting, especially where cryptic or prized specimens that are worth more money were located.

The octocoral collectors interviewed stated they are cautious about storage methods, because negative interactions between species can occur. For example, the slimy sea plume, Antillogorgia Americana, is not sold in the aquarium trade because the excess slime it produces fouls the water during storage and shipment, killing other octocorals within the same aquarium system. Other "sea plumes" (Antillogorgia spp.) reportedly are caustic to other octocoral genera. The high concentration of prostaglandins in Plexaura homomalla (Bundy, 1985) causes caustic reactions when stored with other octocorals, even individu- 


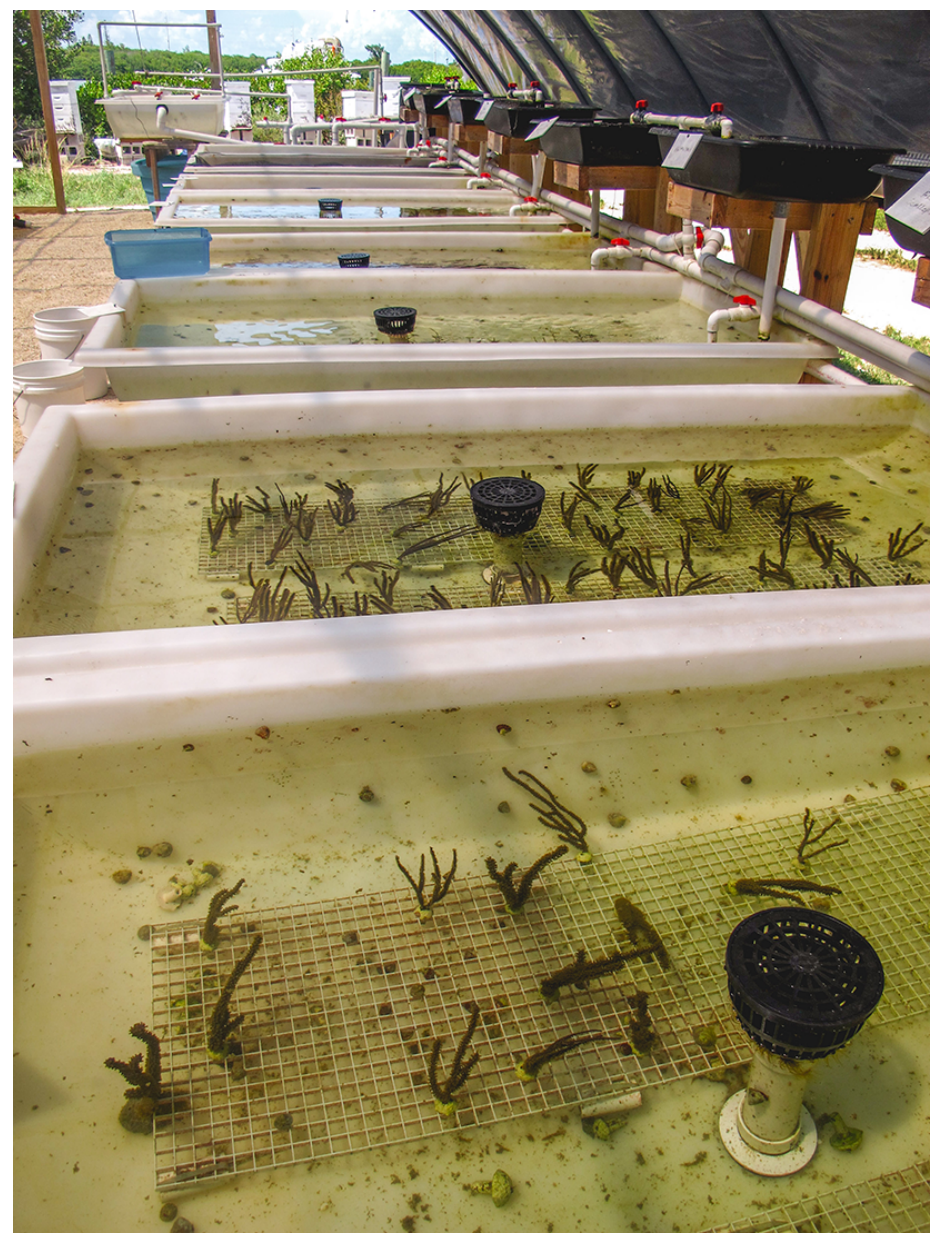

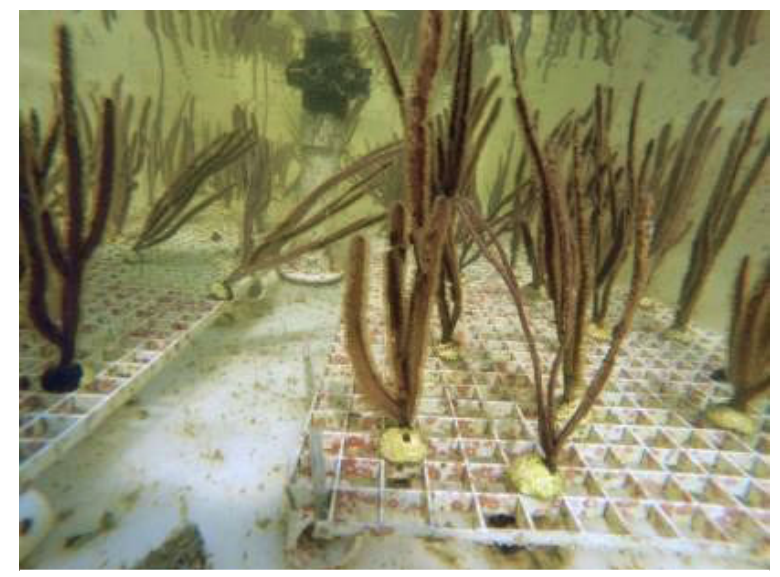

Figure 3.-Eco-Gorgs ${ }^{\circledR}$ are kept upright in flat plastic egg crates within a greenhouse holding facility in the Florida Keys.
Figure 2.-CGreenhouse style octocoral holding facility in the Florida Keys. als from the same species. One collector reported that some morphologies of Eunicea flexuosa will "burn" the tissue of other octocorals, causing it to slough off. Plexaurella species and some deepwater species such as Ellisella barbadensis, Nicella schmitti, and Swiftia exserta are reportedly sensitive to physical damage and to allelochemical interactions with other species, so collectors keep these fauna in individual bags during collection and storage. Collectors who sell the deepwater octocoral Diodogorgia nodulifera, on the other hand, described this species as hardy and indicated that colonies can be housed in close proximity with conspecifics and $S$. exser$\mathrm{ta}$. While none of this information is proprietary, collectors have learned by trial and error how to best collect and store octocorals to maximize profit by minimizing the number of specimens collected and maximizing their survival after collection. This contrasts, for example, with the way that some marine ornamental species, particularly fishes, are collected internationally such as in the Philippines, where large numbers are collected from reefs and only a few survive to be sold to consumers (Wood, 2001).

Collected octocorals are usually housed in long raceway aquaculture tanks ( 4.6 m x $0.6 \mathrm{~m}$ x $0.6 \mathrm{~m}$ ) located in greenhouses or warehouses (Fig. 2). Two of the facilities visited have direct access to bay or inlet waters and had a flow-through water filtration system. Other operations mix their own saltwater $(n=12)$ or have it trucked in $(n=1)$, and then ship octocorals in treated water. Octocoral colonies with slender branches, such as sea plumes, are stored upright with their holdfasts buried in a bed of sand or fine gravel substrate, while those with more robust branches (e.g., Eunicea and Pseudoplexaura species) are suspended upside-down with their holdfasts secured within a piece of foam (similar to a pool noodle). Fragmented colonies can be stored upright with their plugs secured within sheets of plastic egg crates (Fig. 3).

The length of time octocorals are held within a warehouse facility before being shipped ranges from several hours to several weeks. Some collectors wrap wet paper towels or newspaper around individual colonies, and then place six wrapped colonies in a plastic bag with a small amount of wa- 


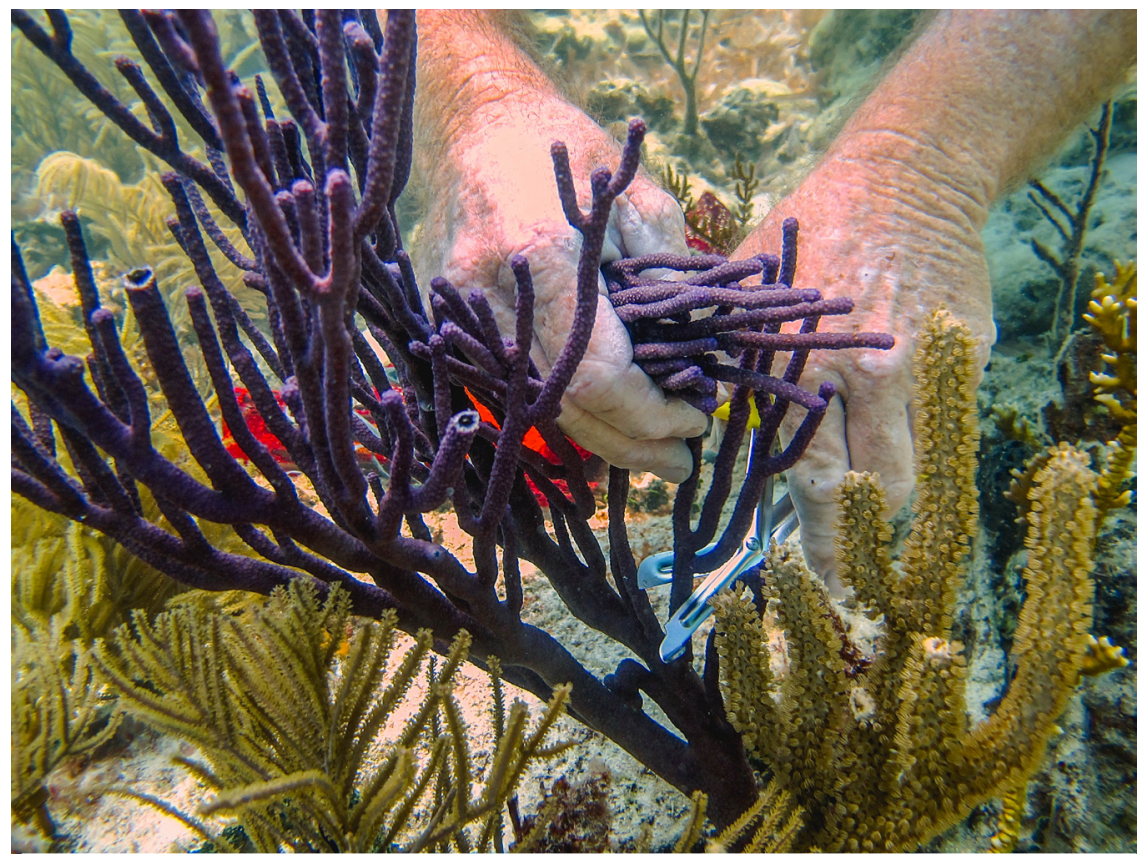

Figure 4.-Branch fragments being clipped from a Eunicea flexuosa colony to be sold as Eco-Gorgs ${ }^{\circledR}$.

ter. Wrapping the colonies keeps them moist and self-contained, which helps to minimize contact with other colonies if they start to deteriorate during shipping. For high-volume shipments of 100 or more colonies, this technique is too labor intensive. Some collectors have had inconsistent results with wet paper towels, so they instead pack individual colonies in small plastic bags and inject hospital-grade oxygen along with a small amount of water to keep the colonies wet. Another method used is to place only the holdfast in water and then hand-vacuum-seal the bag; however, many collectors noted that air exposure kills the colonies. Depending on the species, a dozen or so colonies can be placed in a single bag (e.g., D. nodulifera and Leptogorgia spp.), while other octocorals must be packed individually (e.g., P. homomalla). To minimize costs associated with colony holding and shipping, one collector transfers his collection from the vessel to live wells in the back of a truck, and then delivers the octocorals directly to wholesalers, which keeps the process simple and lowers costs.
A growing number of collectors are adopting the Eco-Gorg ${ }^{\circledR 5}$ technique, in existence since at least the early 1990s, to reduce potential collecting impacts on colonies and populations. The Eco-Gorg ${ }^{\circledR}$ technique involves clipping branch tips $\sim 10-\mathrm{cm}$ in length from larger established colonies (Fig. 4), instead of removing entire colonies from the seabed. From 1 to 20 branch tips per colony are removed and after the colony base of each clipping is stripped of its tissue, they are inserted into concrete plugs and super-glued into place (Fig. 5). The clippings are kept in holding tanks for a few weeks to allow tissue to grow over the concrete plug. The collectors interviewed stated that if they keep octocorals longer in their holding facility, then the colonies acclimate better to an aquarium environment, thus making them hardier for customers. Species fragmented and marketed as Eco-Gorgs ${ }^{\circledR}$ include Antillogorgia acerosa, Briare-

${ }^{5}$ Mention of trade names or commercial firms does not imply endorsement by the National Marine Fisheries Service, NOAA.

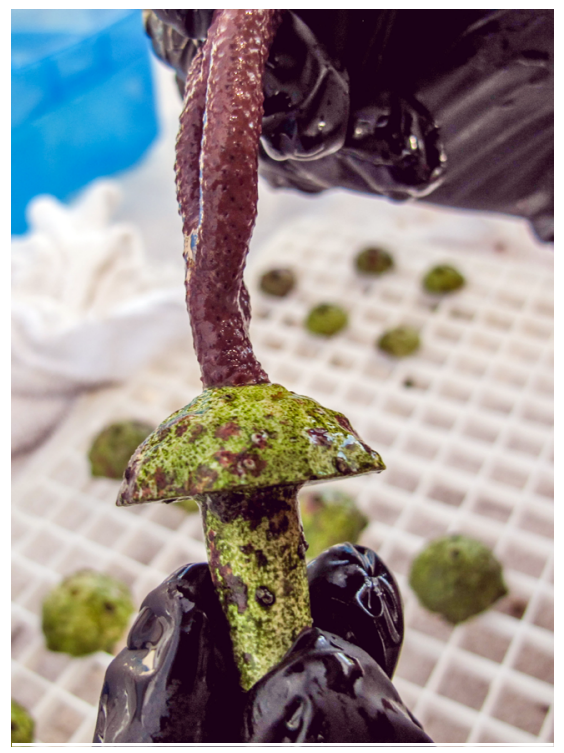

Figure 5.-Eunicea flexuosa fragment is super-glued into a concrete plug to be sold as an Eco-Gorg ${ }^{\circledR}$. um asbestinum, Eunicea calyculata, E. flexuosa, E. succinea, Muricea elongata, Plexaura homomalla, and Pterogorgia guadalupensis. One deepwater collector interviewed uses this technique to collect Swiftia exserta more quickly and efficiently in challenging high current, deep-diving conditions. $S$. exserta is collected in Palm Beach County along the edges of the southeast Florida reef tract from 18-46 m depth, where high densities of large colonies are intermixed with Diodogorgia nodulifera and $M$. elongata. Colonies tend to be short and rigid in high-current environments. One collector interviewed also finds these deeper water taxa in Miami-Dade County at $27 \mathrm{~m}$ depth; however, densities are lower and colonies are taller and more flexible at these sites. Between five and ten branch clippings, $20-\mathrm{cm}$ long, are removed from colonies over one meter in height. As many as 70 clippings can be collected in ten minutes. Not all octocorals can be collected using the Eco-Gorg ${ }^{\circledR}$ technique. $D$. nodulifera colonies, for example, lack a proteinaceous central axis and 
thus cannot be adhered to a plug or other substrate for growing out in a holding facility.

Aquarium hobbyists generally desire fragmented colonies for several reasons. First, they are a sustainable alternative to removing whole colonies from the reef. In addition, they offer the potential to introduce more variety to aquariums because specimens that may otherwise be too large can be made available as smaller colonies. The fragments also tend to be hardier, since they have already survived storage in the artificial systems maintained by the collectors or wholesalers. Aquarium hobbyists also state that Eco-Gorg ${ }^{\circledR}$ fragments are easy to establish in their aquariums because they are already accustomed to receiving fragments of stony corals and corallimorpharians attached to plugs. Marine life vendors have begun to adopt the fragmentation process and on occasion request large whole colonies that they clip themselves and then sell as fragments.

\section{Economics of the Fishery}

Octocoral collectors sell to wholesalers, retail stores, hobbyists, and public aquariums both domestically and internationally. One interviewed collector, for example, supplies octocorals primarily to public aquariums, but also sells to wholesalers in China and Japan and a few domestic pet stores. Wholesale dealers and retail stores work closely with one another, so marine life collectors are careful not to undercut wholesalers by dealing directly with retail stores.

Collectors who sell directly to hobbyists are typically working with a "purist" market-where buyers are trying to recreate a reef ecosystem in their home aquaria. Buyers looking for high-quality Caribbean species that are sold at reasonable prices hear about these direct-sale-collectors by word-of-mouth. This results in a steady demand for octocorals that is additionally driven by social media outlets and marine aquarium forums such as ReefBuilders (reefbuilders. com), Reef Central (reefcentral.com), and Coral Magazine (coralmagazine. com). Such networks have contributed greatly to the expanding knowledge base of octocoral care and sales.

The international market for Caribbean octocorals exists because international hobbyists seek out exotic, seemingly rare species to keep in their home aquariums. The collectors interviewed stated that they ship octocoral colonies to Canada, Israel, Ukraine, and Asia, with several also shipping to the European Union despite needing a health certificate from the U.S. Department of Agriculture, along with veterinarian inspections of collection stocks and holding facilities. Germany in particular has become a leading manufacturer of aquariums and aquarium products that serve a popular reefkeeping hobby. When the Cold War political divisions blocked access to aquarium resources, aquarists in East Germany were forced to dedicate their husbandry efforts to a limited number of species, mainly soft corals from the Mediterranean Sea, and to construct their own filtration systems. The reunification of Germany gave rise to greater access to tropical marine animals; however, the popularity of reefcentric aquariums remained and now many home aquariums in Germany are dominated by invertebrates, especially octocorals (Luty, 2014).

The mark-up rate from collector to retailer is approximately 10 -fold, with retailers purchasing colonies from collectors for $\$ 2$ to $\$ 5$ per colony and then selling those colonies for $\$ 20$ to $\$ 50$ each. Working with wholesalers tends to bring reduced prices per colony for the collector; however, collectors can sell 100 colonies at a time rather than just 5-15 colonies. In addition, once a relationship is established between a collector and a wholesaler, wholesalers show loyalty to their collectors and will subsequently purchase from them despite competitors offering lower prices. Collectors do have influence over their distribution and prices, especially when healthy specimens are difficult to find or if collecting conditions such as inclement weather make collecting challenging. The extensive warm temperatures in south Florida in 2014 resulted in massive bleaching of a number of octocoral species including Antillogorgia spp., B. asbestinum, Muricea sp., and Plexaurella spp. In addition, elevated concentrations of the marine dinoflagellate Karenia brevis created an algal bloom off the west coast of Florida ${ }^{6}$, killing a substantial number of octocorals as stated by one collector. In such cases, collectors must travel further distances to find suitable specimens to collect, resulting in price increases to offset extra fuel costs. Deepwater octocoral collectors have an apparent competitive advantage over shallow-water collectors because demand for their specimens is relatively high, due to the vibrant coloration (red, orange, and yellow) of the deepwater colonies. Collectors also work to emphasize the "special" nature of deepwater octocorals by partially filling orders, or only collecting these species every couple of months. Intentional or not, the perception remains that deepwater octocorals are "special," so this places a higher value on colonies (Anonymous collector, personal commun.). However, deepwater octocorals are also more difficult to maintain in good condition in aquaria, reducing demand.

Internal costs associated with collecting marine life organisms are high and include operational costs, maintenance costs, and other associated costs (Table 3). Per week, the collectors interviewed stated that they could spend $\$ 400$ on collection trips. For this reason, octocoral collectors sometimes work with other marine life collectors to fill gaps in their own supplies. Other costs include annual renewal fees such as the $\$ 550$ fee for a Wholesale Dealer License. Unforeseen costs include fines from FWC; for example, for not using an air stone or recirculating live well to keep octocorals in a healthy condition, or the revocation of an ML license for failure to report Trip Ticket data (e.g., loss of the purchase

${ }^{6} \mathrm{FWC}$. 2014. Red tide current status, accessed 14 Dec. 2014 at https://myfwc.com/research/ redtide/statewide/. 
Table 3. - Costs associated with owning a marine life collection business according to interviewed octocoral collectors in Florida.

\begin{tabular}{l}
\hline \multicolumn{1}{c}{ Costs } \\
\hline Operational \\
Fuel (personal vehicles) \\
Fuel (boat) \\
Warehouse facility rental/mortgage \\
Aquarium system setup \\
Electricity \\
Staff/crew, food, ice \\
Maintenance \\
SCUBA gear \\
SCUBA tank fills \\
Boat \\
Aquarium products (water, salt, etc.) \\
Packing and shipping supplies \\
Associated \\
License/endorsement renewal \\
Insurance (personal vehicle) \\
Insurance (boat) \\
Insurance (facility) \\
International shipping fees
\end{tabular}

price and sales associated with the ML license).

\section{Challenges in the Octocoral Fishery}

The biggest challenge faced by octocoral collectors is the relatively low demand for colonies by aquarium hobbyists, as well as finding and retaining customers. Maintaining live octocorals in aquaria is also a difficult and relatively costly hobby, compared to maintaining only fishes. In addition, there are substantial physical challenges inherent when diving and collecting marine life. Long days spent on the water mean exposure to the elements, venomous marine life such as lionfish, Pterois spp., and jellies, and physical fatigue. Marine life collection can also require diving expertise, especially when diving in strong currents and deeper water. Palm Beach County is notorious for its high-current regime due to the proximity of the Gulf Stream to the coast, so collectors prefer to drift dive with their boat. Many collectors operate alone while diving because they feel safer not having to keep track of a dive buddy. Limited market potential and difficulty collecting combine to make octocoral collecting a niche business, usually a small part of a larger enterprise that involves collecting a diversity of marine organisms.

Adverse environmental conditions,

Table 4.-Annual landings, number of collection trips, average price per colony, and estimated value of octocorals in State and Federal waters in Florida, 1994-2012, based upon commercial marine life trip ticket data (FWC, 2014).

\begin{tabular}{lcccc}
\hline Year & No. collected & Total trips & Average price/colony $(\$)$ & Estimated value $(\$)$ \\
\hline 1994 & 32,106 & 764 & 3.80 & 121,983 \\
1995 & 35,976 & 889 & 2.42 & 87,186 \\
1996 & 37,057 & 702 & 2.80 & 103,739 \\
1997 & 425,867 & 832 & 2.34 & 104,866 \\
1998 & 40,743 & 790 & 2.23 & 91,029 \\
1999 & 36,621 & 997 & 2.50 & 107,662 \\
2000 & 43,100 & 956 & 2.60 & 119,304 \\
2001 & 45,894 & 880 & 2.51 & 95,731 \\
2002 & 38,138 & 926 & 2.63 & 117,140 \\
2003 & 44,484 & 1,018 & 2.74 & 119,802 \\
2004 & 43,708 & 905 & 2.88 & 119,515 \\
2005 & 41,452 & 1,004 & 2.96 & 143,538 \\
2006 & 48,567 & 864 & 3.29 & 145,759 \\
2007 & 44,273 & 826 & 3.57 & 152,029 \\
2008 & 42,642 & 784 & 2.93 & 124,533 \\
2009 & 42,481 & 695 & 4.08 & 131,529 \\
2010 & 32,237 & 701 & 3.52 & 101,780 \\
2011 & 28,942 & 625 & 3.85 & 127,839 \\
2012 & 33,228 & & &
\end{tabular}

such as temperature-related bleaching events and algal blooms, can weaken and cause octocoral mortality, making it difficult to find viable specimens to sell. Even healthy colonies can quickly deteriorate and become unviable if they are not handled or stored properly. In addition, maintaining octocoral colony health in an aquarium system is challenging because octocorals require adequate spacing among colonies, water quality, appropriate lighting (e.g., lower light output for deeper water octocorals), and relatively strong water flow. Deepwater species also require a supplemental food source since they lack symbiotic microalgae (zooxanthellae). Aquarium system construction and maintenance is also expensive. Some collectors who do not live near a clean source of saltwater have to pay for saltwater transported to their warehouses.

Economically, the octocoral industry supplies the larger aquarium trade, which is itself a luxury hobby, especially as related to keeping live corals and octocorals. Price fluctuations and octocoral supply problems are largely uncontrollable by collectors. For example, when healthy octocoral colonies become scarce due to bleaching, algal blooms, or other factors related to environmental stress, collectors must travel further distances to find viable colonies, which, in turn, raises the price of octocoral colonies. Hobbyists are usually unaware of the causes of price increases, so they often turn to less expensive sources or alternative species from international markets. For instance, a collector interviewed from the Florida Keys who was mining natural live rock in the 1980s stated that once the State of Florida prohibited live rock collecting in State waters in 1992 (FAC 68B-42.008), marine aquarium hobbyists shifted their attention to Haiti to acquire inexpensive Caribbean live rock. During economic downturns, such as the recession of 2008 , the price per octocoral colony declined (Table 4) because of less disposable income to spend on luxury aquarium items, which, in turn, placed pressure on collectors' daily maintenance and operation costs (Table 3 ). Coupled with the relatively low demand for octocorals (historically and presently), collectors typically rely on other marine life species to increase profits. During the past 20 years in Florida, snails, crabs, starfish, shrimps, and anemones constituted the most popular aquarium invertebrates sold to the aquarium trade (Table 5).

\section{Future of the Fishery}

The state of the octocoral fishery has remained relatively stable since 1994 (FWC, 2014). In the last six years, however, there has been a decline in demand of octocorals by aquarium hobbyists (Table 4). The marine aquarium hobby is susceptible to trends, much like the fashion industry 
Table 5.-Annual landings and economic value of marine invertebrate species groups collected in Florida, 19942012, based on commercial trip ticket data (FWC, 2014).

\begin{tabular}{|c|c|c|c|c|c|c|}
\hline \multirow[b]{2}{*}{ Invertebrate group } & \multicolumn{2}{|c|}{ Annual landings } & \multirow{2}{*}{$\begin{array}{c}\text { Change in landings, } \\
1994-2012(\%)\end{array}$} & \multicolumn{2}{|c|}{ Value (\$) } & \multirow{2}{*}{$\begin{array}{l}\text { Change in value } \\
1994-2012(\%)\end{array}$} \\
\hline & 1994 & 2012 & & 1994 & 2012 & \\
\hline Snails & 290,211 & $3,308,614$ & 1,040 & 173,812 & 449,102 & 158 \\
\hline Crabs & 117,889 & $2,667,574$ & 2,163 & 100,617 & 543,191 & 440 \\
\hline Sand Dollars & 643,105 & $1,484,091$ & 131 & 64,631 & 143,110 & 121 \\
\hline Shrimp & 33,719 & $1,754,445$ & 5,103 & 32,374 & 353,760 & 993 \\
\hline Starfish & 314,071 & 25,414 & -92 & 298,922 & 40,705 & -86 \\
\hline Anemones & 307,891 & 65,626 & -79 & 164,671 & 136,621 & -17 \\
\hline Octocorals & 32,106 & 33,228 & 3 & 121,983 & 127,839 & 5 \\
\hline
\end{tabular}

changing styles from year-to-year. One of the most popular current trends is related to aquarium lighting. Advances in lighting technology have replaced large, heat-producing, energy-draining lights with more compact, energy-efficient LED lights that provide focused light into reef tanks (Joshi, 2010). Actinic lights have also become popular in reef aquariums because they highlight the fluorescence within coral polyps. As a result, saltwater aquariums are no longer dominated by just fishes, but by other colorful species such as corallimorpharians and zoanthids. Since most octocorals apparently do not fluoresce under such lighting conditions, they are not currently part of this trend.

Aquarium hobbyists also seek shortcuts in reducing the time it takes to perform maintenance duties on home aquaria, such as siphoning out excess food and detritus or removing algae. As a result, "cleaner" invertebrates such as snails and crabs are now common elements in aquariums. Because marine hobbyists often spend a lot of time, effort, and money, they enjoy sharing and showing off their aquaria. Several marine aquarium forums have "tank of the month" pages (e.g., www. reefcentral.com, Reefkeeping Magazine, and Ultimate Reef) that encourage hobbyists to send in photographs of their home aquariums for others to learn from or to reserve "bragging rights" for a job well done. Part of this social dynamic is seen in the variety of species within these tanks. Exotic and rare species such as the peppermint angelfish, Centropyge boylei, a deepwater angelfish known to only inhabit the Cook Islands, are highly sought after, despite the $\$ 20,000$ retail value
(Ho, 2011). Since octocorals are not considered rare or exotic (at least in the U.S.), they are not currently part of this trend.

What would need to occur for the octocoral fishery to boom in Florida or the greater southeastern U.S. and in octocoral collection-and it was small-occurred in the mid-1990s after culture techniques were developed that were relatively easy for home aquarium hobbyists to adopt. During this period, octocorals became associated with keeping seahorses in aquariums, which elevated octocoral demand slightly. On a limited scale, the encrusting octocoral Erythropodium caribaeorum was once collected for a unique ceutical properties. The biocompound, however, was synthesized quickly by a Canadian company, subsequently resulting in reduced demand for this species (Taglialatela-Scafati et al., 2002). The only other actively collected octocoral for the pharmaceutical industry presently, at least that we are aware of, is Antillogorgia elisabethae, which is collected in the Bahamas and perhaps elsewhere (Castanaro and Lasker, 2003). Typically, when a bioactive compound is isolated from a marine species with potential for commercial application, considerable effort is expended to synthesize the compound in the laboratory, since collection from natural populations rarely provides a reliable or sustainable source of the bioactive material. It is possible that an octocoral species could suddenly become fashionable and result in increased demand. For example, EcoGorgs ${ }^{\circledR}$ were first introduced in the late 1990 s, and then declined in popularGulf of Mexico? The only real boom secondary metabolite that had pharma- ity. Demand then increased when they were re-introduced due to demand for apparently sustainable and ecologically friendly products. Working against the trade is the fact that the most colorful species are typically the most difficult to collect, as they are usually the deeper water species found in high-current regimes. Such fauna are also more difficult to maintain in good condition in hobbyist aquariums. In the mid-1990s, for example, "red" octocorals were marketed at a higher price point because they were clearly attractive as ornamentals, but demand could not be sustained.

The octocoral collectors interviewed have a positive outlook on the future of the octocoral fishery, yet are realistic when discussing the future. Collectors have experienced trends that fluctuate with the vagaries of the aquarium trade, yet they have adhered to collecting and selling octocorals typically because there are reliable buyers who provide a relatively small but steady income. A few of the collectors interviewed spoke optimistically about the potential for growth as hobbyists begin to learn more about octocoral husbandry requirements through aquarium hobby online forums. Technological developments in power heads that simulate wave-driven water movement may also facilitate octocoral husbandry. Collectors are adept at the use of social media outlets to market their marine organisms. Formal, potentially costly, marketing approaches have not apparently been attempted based upon the responses from the collectors interviewed. Some collectors lamented the difficulty in finding reliable customers who keep octocorals in their aquaria, noting flat sales over the years, compared with sales of other invertebrate organisms such as crabs and corallimorpharians. Many collectors interviewed mentioned that they would welcome a concerted effort on the part of the scientific community to validate the sustainability of octocoral collection, which they think might help promote interest and boost sales. Indeed, that is one reason why so many collectors were willing to be interviewed for this study. 
Total Number of Invertebrates Landed in Florida

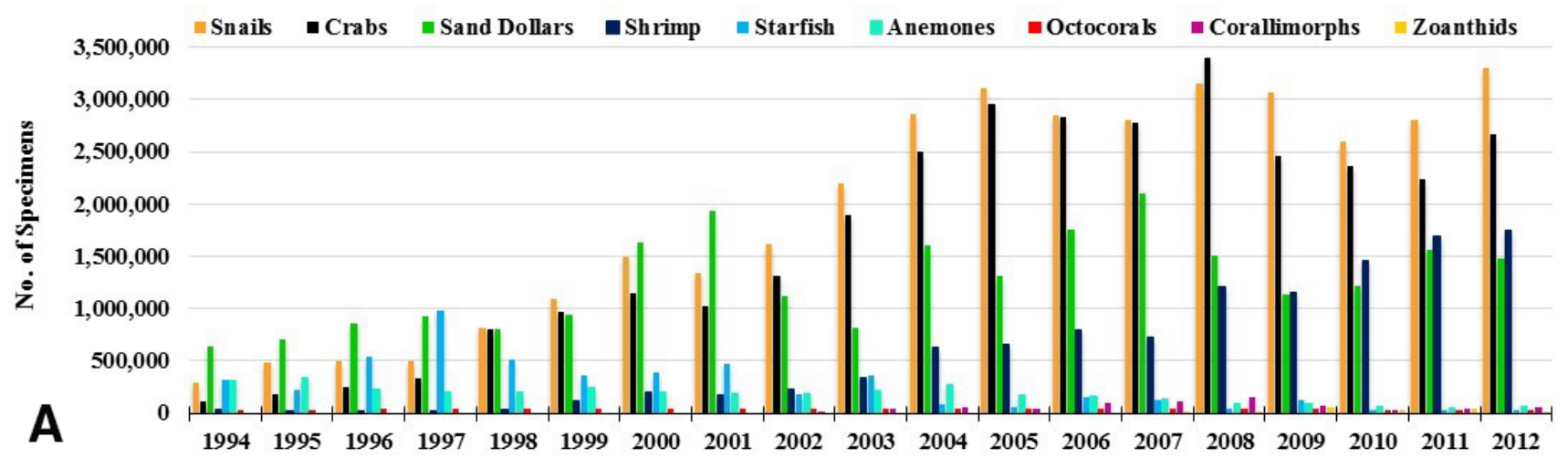

Estimated Dockside Value of Invertebrates in Florida

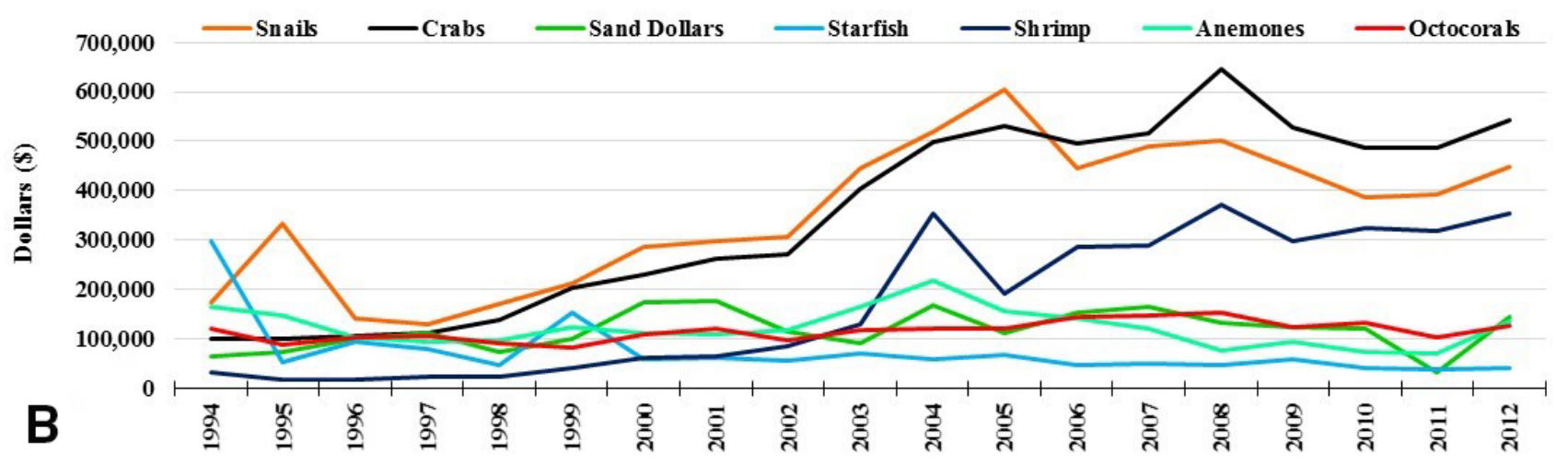

Figure 6.-(A) Annual landings and (B) dockside value of invertebrates for the marine aquarium trade in Florida, 1994-2012 (FWC, 2014).

\section{Commercial Marine Life Landings and Values}

\section{Invertebrates}

A principal driver of the marine life fishery in the U.S. South Atlantic and Gulf of Mexico is that it is a demandbased fishery for aquarium hobbyists and for the curio trade. Historically, the marine aquarium trade has been fish-centric; however, developing technologies in lighting and filtration have advanced the husbandry of invertebrate species, thereby opening the hobby to greater demand for other reef organisms (Rhyne and Tlusty, 2012). For example, during 1990-98, invertebrate landings accounted for an average of $63 \%$ of the total value of annual dockside landings within the Florida marine life fishery (Adams et al., 2001). During this same period, octocorals represented only $4.4 \%$ of all invertebrates collected (Larkin et al., 2001). Instead, gastropod snails, crabs, sand dollars, shrimps, starfish, and anemones represented the top invertebrate groups collected (Fig. 6A). Since the State of Florida FWC began keeping public records of commercial landings in 1994, declines in landings of starfish and anemones have given rise to dramatic increases in the collection of shrimps, crabs, and snails on an annualized basis (Fig. 6A, Table $5)$. The increased demand for organisms that graze algae and scavenge detritus reflects demand by hobbyists for organisms that provide an aquarium service (i.e., control and removal of algal growth and detritus) for their home aquaria (Rhyne et al., 2009).
Sand dollars are collected for the curio trade and experienced a $57 \%$ increase in collection levels since 1994 (FWC, 2014). As demand increases for such organisms, so too does their dockside value. The dockside value of ornamental cleaner shrimp, for example, increased by $52 \%$ on an average annualized basis from $\$ 32,374$ in 1994 to $\$ 353,760$ in 2012 . Crab, snail, and sand dollar values exhibited similar increases in value (Fig. 6B, Table 5).

\section{Octocorals}

Octocorals are valued because at least some specimens provide aesthetic beauty to home aquaria. However, because most octocorals lack the color vibrancy of other invertebrates, they have not experienced the same collection intensity as other marine life 
Average Landings and Dockside Value of Octocorals

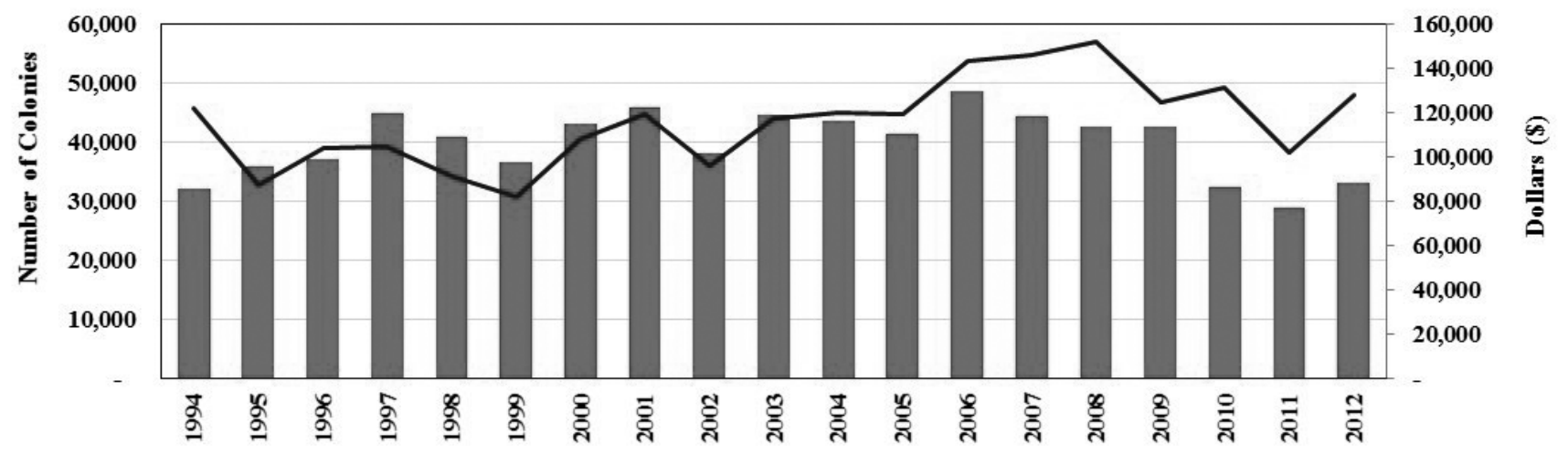

Figure 7.-Average annual landings (bars) and dockside value (line) of octocorals collected in Florida, 1994-2012 (FWC, 2014).

organisms. Since 1990, the FWC has collected annual landings data that includes the number of octocoral colonies landed; however, landings are not partitioned by taxonomic classification but instead by color categories (FAC 68B-42.001). According to the FAC (Rule 68B-42), the term "octocoral," which also includes "soft coral," means "any erect, non-encrusting species of the subclass Octocorallia, except the species Gorgonia flabellum and Gorgonia ventalina." FWC also collects commercial octocoral fishery data pertaining to the number of collection trips made, average price per colony, and average dockside value of octocorals using trip ticket reports. As reflected in nearly 20 years of available commercial trip ticket data, octocoral annual landings increased by only $3 \%$, while the price per colony has nearly doubled, from $\$ 2.23$ in the late 1990 s to $\$ 4.08$ in 2010 (Fig. 7, Table 4). Noteworthy is that the price per specimen is considerably higher than for many other invertebrate groups, which generally sell for less than $\$ 1.00$ per specimen. In 2006 , the octocoral fishery experienced a surge in hobbyist demand, resulting in 48,567 colonies collected during 1,004 commercial trips (Fig. 7, Table 4). Julian Sprung (2004), a marine aquarium expert and author of several books on the topic, wrote an article in Advanced Aquarist Magazine detailing the life history traits and husbandry requirements for several octocoral species, providing aquarium hobbyists with a user's manual for maintaining octocorals. By 2006, an article describing octocoral propagation techniques was published in Reefkeeping (Hiller, 2006), another popular online marine aquarium magazine, making these techniques more widely accessible to the home hobbyist. Also during this time, the use of octocorals in seahorse aquariums became popularized as images and discussions of "seahorse-friendly" organisms became trending topics in marine aquarium forums (www.reefcentral.com/forums, accessed in 2006). The collectors interviewed noted that requests for yellow octocorals increased during this same period, perhaps due to increased online forum traffic.

Since the mid-2000s, the demand for octocorals has declined annually, but the high price-per-unit has produced some of the highest grossing years since 1994 for octocoral collection, as reported in FWC Trip Ticket data. The estimated value of the octocoral fishery peaked at $\$ 145,759$ in 2007 and $\$ 152,029$ in 2008 (Fig. 7, Table 4). At the height of the recession in 2009, the price per colony declined to $\$ 0.67$ and then increased from $\$ 1.15$ to $\$ 4.08$ in 2010 . Demand dropped by $24 \%$ in 2010 (Fig. 7, Table 4). The need for collectors to generate lost income af- ter the 2008 recession was likely the most important factor that drove prices upwards, but low demand by hobbyists reduced the number of colonies collected. The most recent data show a $13 \%$ increase in colony landings and a $\$ 0.33$ increase in price per colony from 2011 to 2012 (Fig. 7, Table 4).

As reported in the FWC Trip Ticket reports (the following regional and species group specific data are unpublished), octocoral landings and dockside value data are available for Florida on a statewide basis (Fig. 8) and further partitioned for the Florida east (Fig. 9) and west coasts (Fig. 10). Approximately $80 \%$ of octocorals are collected from the Atlantic Ocean off the Florida Keys and the east coast of Florida from Monroe County to Palm Beach County. In Florida Keys northward to Palm Beach County, compared to other areas of Florida and the rest of the southeastern U.S., octocoral populations are diverse-species from all of the color groups (e.g., other, purple, and red) are collected (Fig. 9A). The smaller octocoral fishery on the west coast of Florida in Gulf of Mexico waters, concentrated mainly in Hillsborough and Pinellas Counties, is comprised mainly of octocorals in the "other" and "purple" categories. The taxa collected within the "red" species group are Leptogorgia species and Muricea pendula (Fig. $10 \mathrm{~A}$ and Table 2). The "red" species 

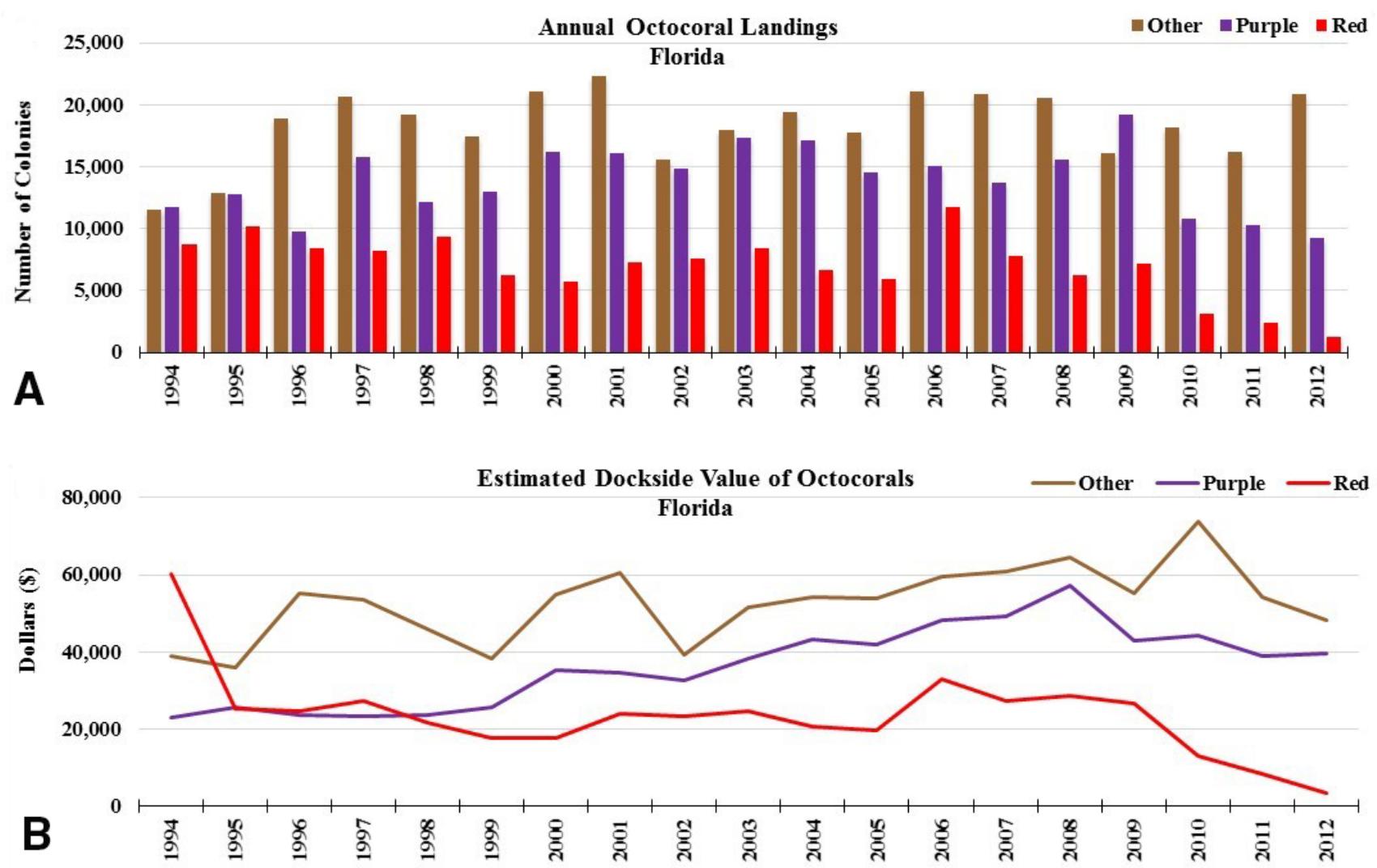

Figure 8.- (A) Annual octocoral landings and (B) dockside value of octocoral species groups (other, purple, and red) in State and Federal waters off Florida, 1994-2012 (FWC, 2014).

code elsewhere usually refers to Swiftia exserta, which has red polyps, but it is possible that other octocorals with a red rind or colony axis are reported under this code. Contrary to what would be expected from an industry that values colorful, seemingly rare species, the demand in the aquarium trade is primarily for octocorals in the "other" species group (Table 6). On average, nearly half (47\%) of all of the octocorals collected annually are species within the "other" species group (18,340 octocorals), primarily (74\%) on the Atlantic Ocean side of Florida (Table 6). However, on average they are sold at a lower price per unit than those collected on the Florida west coast ( $\$ 2.67 /$ colony vs. $\$ 3.75 /$ colony) (Table 6). The difference in unit colony price has not hampered the value of "other" octocoral species collected in Atlantic waters; current (as of 2012) data show the greatest dockside value of octocorals $(\$ 48,128)$ compared to the value of "other" octocorals from the Gulf of Mexico $(\$ 25,955)$ (Fig. 9B and $10 \mathrm{~B}$ ).

Demand for "purple" octocorals began to increase in the early 2000 s (Fig. 8), a period in which small $(<20 \mathrm{~cm})$ whole colonies of Antillogorgia species, Briareum asbestinum, and Pterogorgia anceps were being sold to hobbyists as an alternative to the mostly brown octocorals sold within the "other" species group. However, the diversity of "purple" octocorals available was limited because of the difficulty in finding small, whole colonies suitable for home aquaria. After the 2008 economic recession, collectors began exploring alternative options for increasing the diversity of octocorals that could be brought to market. From this need to diversify and find new income sources, "Eco-Gorgs ${ }^{\mathbb{B}}$ " was developed. To create Eco-Gorgs ${ }^{\circledR}$, several small $(<$ $20 \mathrm{~cm}$ ) clippings were removed from larger adult colonies (Fig. 4), glued to concrete plugs (Fig. 5), and marketed as a sustainable alternative to collecting whole colonies. Additional desirable species (color and/or large polyps) such as Muriceopsis flavida and Plexaurella nutans were then introduced to the market. Octocoral clippings had previously been introduced to the market in 1998, and while they were valued as having a relatively low impact on the ecosystem, they did not introduce any additional selection to the market. Increased interest in ecofriendly approaches and the introduction of new species to the market were what made Eco-Gorgs ${ }^{\circledR}$ more successful the second time around. The dockside market value of "purple" 


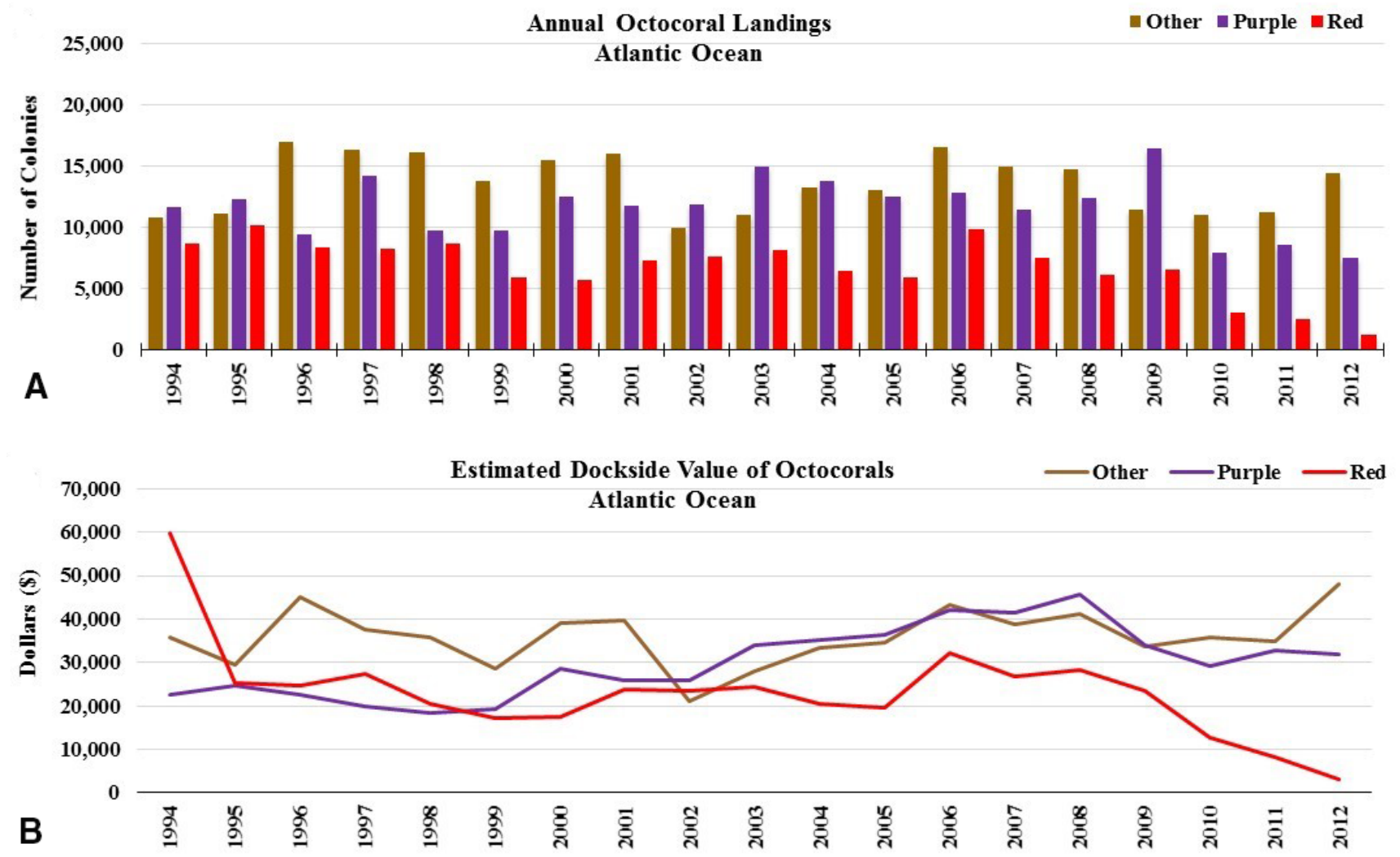

Figure 9.- (A) Annual octocoral landings and (B) dockside value of octocoral species groups (other, purple, and red) in State and Federal waters in the Atlantic Ocean off Florida, 1994-2012 (FWC, 2014).

Table 6.-Average annual landings (no. colonies), numbers of trips, price per colony, and economic dockside value of octocorals collected in Florida in the Atlantic Ocean and Gulf of Mexico during 1994-2012, based on unpublished commercial trip ticket data (FWC, 2014).

\begin{tabular}{lccccc}
\hline Area & Species group & Landings & No. of trips & Price/colony (\$) & Value (\$) \\
\hline Atlantic Ocean & Other & 13,569 & 351 & 2.67 & 36,018 \\
& Purple & 11,638 & 329 & 2.66 & 30,046 \\
& Red & 6,734 & 104 & 3.42 & 23,083 \\
Gulf of Mexico & & & & & \\
& Other & 4,771 & 190 & 3.75 & 17,897 \\
& Purple & 2,317 & 92 & 2.74 & 6,322 \\
& Red & 454 & 14 & 2.63 & 763
\end{tabular}

octocorals peaked in 2008 at $\$ 57,171$ (Fig. 8B) and in 2009, demand for "purple" octocorals reached a high of 19,228 colonies (or fragments) collected (Fig. 8A).

Within the "purple" species group, eight species or taxa of octocorals are collected in Atlantic Ocean waters, three of which are also collected in the Gulf of Mexico: Antillogorgia species (sea plumes) and the sea whips Pterogorgia anceps and $P$. guadalupensis (Table 2). The greater diversity and abundance of "purple" octocoral taxa in the Atlantic supports $84 \%$ of the overall collection of these species (Table 6). Purple octocoral dockside values in the Atlantic surpassed that of the "other" octocoral species group from 2002-09 (Fig. 9B), while landings were greatest in 2009 (Fig. 9A). As of 2012, the average annual price per colony of "purple" octocorals was higher than any other year (\$4.30/colony) for this and species collected within the "other" octocoral group complex.
Initial attempts in 1994 to make a large profit margin off the colorful "red" octocoral varieties (Table 2) by selling them at over $\$ 6.50 /$ colony failed. The following year, "red" octocorals were sold at $\$ 2.48 /$ colony and have since sold for an average of $\$ 3.14 /$ colony. Though these octocorals fit the desired color profile of an ornamental organism, they are typically found at depths ranging from 25 to $60 \mathrm{~m}$ and may lack zooxanthellate. Without zooxanthellae, deepwater octocorals rely solely upon tentacle capture of plankton for their nutrition. Keeping deepwater octocorals in home aquaria therefore means hand-feeding the colonies live or frozen food mixtures. Presumably because they are more difficult to care for, demand for "red" octocorals declined in Florida by 75\% since 2006 (Fig. 8A). Collection efforts have also declined from 272 


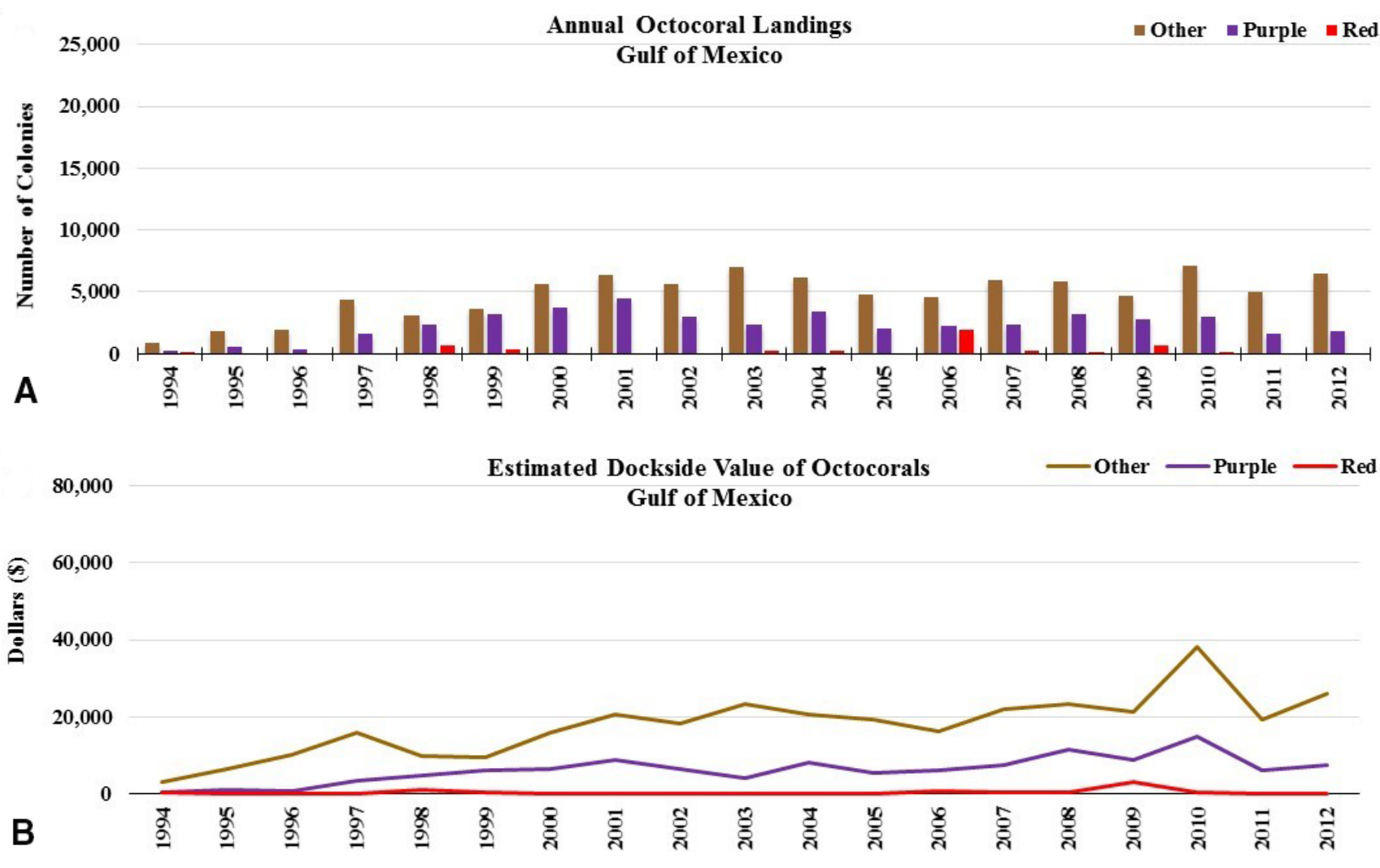

Figure 10.-(A) Annual octocoral landings and (B) dockside value of octocoral species groups (other, purple, and red) in State and Federal waters in the Gulf of Mexico off Florida, 1994-2012 (FWC, 2014)

trips annually in 2001 to 111 trips in $2012\left(\right.$ Sheridan $\left.^{7}\right)$, with only a handful of collectors willing to work at deeper diving depths and with strong currents. Those that do collect deeper water colonies focus their efforts on the east coast of Florida off of Palm Beach, Broward, and Miami-Dade Counties. On average, 104 collecting trips are made annually, yielding 6,733 "red" octocorals with a dockside value of $\$ 23,082$ (Table 6). In comparison, on average, 454 "red" octocorals (primarily Leptogorgia species, Table 2) were collected in the Gulf of Mexico during 10 out of the last 19 years, yielding an average annual dockside value of $\$ 763$ (Table 6).

\footnotetext{
${ }^{7}$ Sheridan, N. 2014. Octocoral harvest from state vs. federal waters by Gulf of Mexico vs. Atlantic waters, 1994-2013. FWC unpubl. data, personal commun.
}

\section{Biology and Ecology}

\section{Overview}

A concern raised with the fisheries for marine ornamental, aquarium, and curio species in the U.S. South Atlantic and elsewhere is the lumping of species with potentially different biogeographic and habitat distributions, as well as life history parameters (e.g., growth and reproduction) in broad categories (Rhyne et al., 2009). The octocoral fishery in the U.S. South Atlantic and Gulf of Mexico, where the majority of the octocoral collection occurs in Florida waters, is no exception. Octocorals collected in Florida waters of the U.S. South Atlantic and Gulf of Mexico span genera and families that are categorized into color varieties for reporting under the FWC Trip Ticket program. Quotas and landings are presently designated into one of three color categories (purple, red, and other), although octocoral collectors often distinguish genera and species. FWC biologists have proposed a new reporting system based upon morphology $\left(\right.$ Brinkhuis $\left.^{8}\right)$. At issue is that species with life history patterns that render them perhaps more resilient to collection (e.g., rapid growth, high recruitment, and broad distribution) are lumped with species that may be less resilient to over-collection because of slower growth, delayed reproduction, lower recruitment, slower regeneration from injury, and/or restricted geographic distribution or habitat/depth distribution. One goal of this study was to address the poor taxonomic

${ }^{8}$ Brinkhuis, Vanessa. Florida Fish and Wildlife Conservation Commission, Fish and Wildlife Res. Inst., Personal commun., Oct., 2013. 
resolution in the octocoral fishery to evaluate if sub-components of the fishery might be more or less sustainable, and thus perhaps require different management strategies. By addressing these data gaps and providing the best scientific information to the South Atlantic Fishery Management Council and the State of Florida, improved management of the octocoral fishery is a hopeful outcome, with ideally the least economic impact to the collectors that depend financially upon octocoral resources.

The narrative below provides an overview of octocoral biology and ecology, with a focus on those species targeted in the octocoral fishery in the U.S. South Atlantic and Gulf of Mexico. The number of species investigated was determined by consultation with collectors, as they are only required to note color categories on Trip Tickets, and available landings data from the State of Florida do not show any further taxonomic resolution. Dr. H. Feddern, an octocoral collector, indicated that he personally collects at least ten genera, with seven taxa identified to the species level from samples confirmed by State of Florida biologists using sclerite samples (Table 1). Further consultation and interviews with other collectors indicated a rather broad range of families, genera, and species that are targeted, represented by 15 genera and at least 23 species (Table 2). As most of these taxa are collected primarily in the Florida Keys, the focus of the overview of octocoral biology and ecology concerns those genera and species identified by collectors, along with sister taxa within genera in cases where only a genus (e.g., Eunicea spp. or Muricea spp.) was identified as being targeted. A substantial compilation of speciesspecific information is presented in the Appendix ${ }^{9}$, which synthesizes much of the available information on geographic distribution, depth range, habitat, and life history information (e.g., growth, recruitment, and sources

\footnotetext{
${ }^{9}$ The appendix is available in the online version of this article (doi: https://doi.org/10.7755/ MFR.80.3.2).
}

of mortality) for the main suite of octocorals collected for the marine life aquarium and ornamental trades in the U.S. South Atlantic and Gulf of Mexico. Much of the available literature stems from octocoral studies in Flori$\mathrm{da}$, as well as the wider Caribbean or tropical western Atlantic. Primary and gray literature sources were reviewed, along with field survey information, to compile species profiles (Appendix). Cairns et al. (2002) list 102 octocoral taxa for U.S. Atlantic waters out to the edge of the continental shelf, not including Puerto Rico and the U.S. Virgin Islands. Octocoral collectors in Florida target at least 23 species, not including species groups such as Antillogorgia spp., Eunicea spp., and Muricea spp. Information for 51 octocoral species among 16 genera was part of this study, including all of the targeted species in the octocoral fishery, as well as many sister taxa, especially where collectors noted genera instead of species.

\section{General Aspects of Biology}

Octocorals include the soft corals, sea fans, blue corals, and sea pens and belong to the Phylum Cnidaria (Coelenterata), an ancient (pre-Cambrian) and diverse assemblage of mostly marine organisms also including jellies, sea anemones, corals, and hydroids (Fabricius and Alderslade, 2001; Cairns et al., 2002; Brusca and Brusca, 2003). Diversity within the phylum stems from two fundamental aspects of many cnidarian life cycles: 1) the tendency to form colonies by asexual reproduction and 2) dimorphic alternation of generations as polyps and medusa exhibited by some groups. Like other cnidarians, octocorals are diploblastic organisms (epidermis, gastrodermis, and mesoglea) at a tissue grade of construction, characterized by radial symmetry, tentacles, stinging structures (cnidae with nematocysts), an incomplete gastrovascular cavity with only one opening (the mouth), and a middle layer of mesenchyme or mesoglea (Brusca and Brusca, 2003). The mesoglea in octocorals, called the coenochyme, can contain fibers and skeletal elements consisting of calcareous spicules or sclerites (Lewis and Von Wallis, 1991). In most octocorals, the sclerites are arranged in three distinct layers in the coenochyme, generally small $(0.05-1 \mathrm{~mm})$, and produced by specialized cells (Lewis and Von Wallis, 1991). The outer cortex or surface layer of the octocoral colony can be variable in sclerite composition, but generally, only one type of sclerite occurs (Bayer, 1961). Octocoral sclerites, along with field characters such as branching patterns, are often needed to confirm field identification (Bayer, 1961).

Octocorals are modular organisms, similar to reef-building corals (Scleractinia), where the basic module is the polyp; growth is indeterminate, with no indication of senescence (Jackson, 1991). Thus, portions of a colony may die due to injury, overgrowth by other organisms, or predation (Jackson, 1991; Castanaro and Lasker, 2003). Octocorals are benthic, sessile, passive suspension feeders, but many species, especially in shallower water, derive nutrients from intracellular algae (zooxanthellae) and thus can be classified as zooxanthellate or azooxanthellate. Azooxanthellate corals rely solely on particle capture by the tentacles to fulfill their nutritional requirements.

Classification of octocorals, like for many groups of organisms, has undergone significant changes in the past decades, with various reclassifications and renaming (Bayer, 1961, 1981; Fabricius and Alderslade, 2001; Cairns et al., 2002). Besides scientific names, various common names are used by octocoral collectors, recreational divers, and scientists (Voss et al., 1969; Cairns, 1977; Cairns et al., 2002). Within the phylum, octocorals are grouped under the class Anthozoa that contains nine orders and $\sim 6,000$ extant species. Within the Class Anthozoa all of the octocorals are in the Subclass Octocorallia (=Alyconaria). They are characterized as colonial organisms containing polyps with eight hollow, marginal, and usually pinnate (feathery) tentacles, along with eight complete mesenteries, with free or fused 
sclerites embedded in mesenchyme (Brusca and Brusca, 2003). The pinnate or feathery tentacles are covered with sensory cells and stinging capsules (cnidae), and may contain symbiotic algae (zooxanthellae). Stolons or coenochyme connect the polyps, with new polyps usually formed by budding from existing stolons. Octocorals comprise a diverse assemblage of organisms commonly referred to as soft corals, sea fans, gorgonians, blue corals, and sea pens. In the literature and in the vernacular, the term "soft coral" sometimes refers to Octocorallia, which have no massive skeleton or internal axis, but sometimes this term also includes sea fans (Fabricius and Alderslade, 2001). The term "sea fan" is sometimes used as an alternative for gorgonian, which are Octocorallia other than sea pens that grow upwards from the substratum with the support of an internal axis (Fabricius and Alderslade, 2001).

Soft corals and gorgonians were formerly classified separately in the Orders Alcyonacea and Gorgonacea, respectively; however, they are now grouped together under the Order Alcyonacea (Bayer, 1981; Fabricius and Alderslade, 2001; Cairns et al., 2002). Most of the octocorals collected for the marine aquarium and ornamental (curio) trades in the U.S. South Atlantic and Gulf of Mexico consist of sea whips, sea rods, and sea plumes, distributed among 4 suborders and 12 families (Cairns et al., 2002). Colonies are usually brightly colored and arborescent with a firm internal axial skeleton composed of horny proteinaceous material (gorgonin) that contains modified collagen and may be mineralized. Occasionally the skeleton is calcareous, but colonies are always covered with a thin layer of scleritefilled mesoglea, which provides colony support and protection (Bayer, 1961; Lewis and Von Wallis, 1991). Surface sclerite (spicule) shape is used to identify octocorals (Bayer, 1961), along with patterns in the colony growth axis (Cairns, 1977). Octocoral growth morphology and even the structure of the spicules can vary over different depth and water flow regimes (Bayer 1961; Lewis and Von Wallis 1991). Octocorals are one of the more difficult groups of organisms to identify, and may explain why the Federal and State of Florida reporting requirements currently consist of color categories.

\section{Biogeography}

Octocorals are broadly distributed in the marine environment, present in every ocean basin from the tropics to polar regions, from the intertidal zone to abyssal depths (Bayer, 1961; Fabricius and Alderslade, 2001). The western central Pacific harbors the greatest number of octocoral species (90 genera and 23 families), but the western Atlantic also include a relatively high number of species (Bayer, 1961; Cairns et al., 2002). The American Fisheries Society (AFS) Committee on Common Names of Aquatic Invertebrates (CNAI) lists 102 octocoral taxa for U.S. Atlantic waters (exclusive of Puerto Rico and the U.S. Virgin Islands) that inhabit contiguous shore waters on or above the continental shelf to a depth of 200 $\mathrm{m}$. The focus herein is on geographic distributions pertaining to those genera and species targeted by the octocoral fishery from North Carolina to Texas, with a particular emphasis on south Florida.

Broad-scale (i.e., wider Caribbean) geographic patterns of 51 octocoral species are listed in Table 7 . The majority of shallow-water $(<20 \mathrm{~m}$ depth) species have a relatively broad distribution across the wider Caribbean, largely mirroring the distribution patterns of stony corals, concentrated in warmwater $\left(18-31^{\circ} \mathrm{C}\right)$ regions, possibly due to the relatively narrow temperature tolerance of microalgae (zooxanthellae) (Fabricius and Alderslade, 2001). Approximately 170 species of gorgonian octocorals occur in the West Indian Province (wider $\mathrm{Ca}$ ribbean), which includes Bermuda, the Bahamas, the Greater and Lesser Antilles, south Florida, the Gulf of Mexico, and the Caribbean coasts of Central and South America (Cairns, 1977). Many of these taxa ( 100) oc- cur below $50 \mathrm{~m}$ depth and/or are found in temperate waters (Bayer, 1961; Cairns et al., 2002). Taxa with deeper depth distributions, beyond where most octocoral surveys are conducted, often have sparse or no biological information (see Appendix).

\section{Habitat and Depth Distribution}

In subtidal habitats, specifically in areas with available hard substratum, octocorals can reach densities approaching 100 colonies $/ \mathrm{m}^{2}$ (Yoshioka, 1998). Environmental parameters such as light, water depth, water motion, sedimentation, and availability of appropriate substrata are the most important determinants of octocoral distribution. For zooxanthellate species, the light regime, influenced by depth and water clarity, but also substratum steepness and stability, are important factors in spatial distribution. In azooxanthellate octocorals, larvae preferentially settle in low light microenvironments and depend on particle capture to meet nutritional requirements. Octocorals can flourish in areas with strong currents and light to moderate wave action. Many species require consistent and moderately strong currents to maximize food encounter rates (Fabricius and Alderslade, 2001). This is most evident, for example, in sea fans, where colony orientation is perpendicular to the predominant current direction to maximize food particle interception. Stronger currents not only transport food towards and waste away from colonies, but also stimulate photosynthesis. Tolerance to sediment loads varies widely among octocoral taxa, with some adapted to clearer waters, while others flourish in moderately turbid waters. Some azooxanthellate species are quite abundant in turbid environments (Opresko, 1973; Fabricius and Alderslade, 2001).

\section{Life History}

Life history refers to an organism's lifetime pattern of growth, development, and reproduction, reflected in an array of adaptations relating to physiology, morphology, and behavior. Life history includes traits that 
Table 7.-Biogeography of octocorals (Cnidaria, Anthozoa, Alcyonaria = Octocorallia) in the Wider Caribbean, with a focus on taxa occurring on the Atlantic and Gulf coasts of Florida, especially those collected for the marine aquarium/curio trade (shaded). Asterisks (*) indicate the most demanded taxa in the U.S. South Atlantic octocoral fishery. Species are grouped by suborders and families according to Cairns et al. (2002).

\begin{tabular}{|c|c|c|c|c|c|c|c|c|}
\hline \multirow[b]{2}{*}{ Octocoral species } & \multicolumn{8}{|c|}{ Wider Caribbean region ${ }^{1}$} \\
\hline & 1 & 2 & 3 & 4 & 5 & 6 & 7 & 8 \\
\hline \multicolumn{9}{|l|}{ Suborder Scleraxonia } \\
\hline Briareum asbestinum & & $\mathrm{x}$ & $\mathrm{x}$ & $\mathrm{X}$ & $\mathrm{X}$ & $\mathrm{x}$ & $\mathrm{X}$ & \\
\hline \multicolumn{9}{|l|}{ Family Anthothelidae } \\
\hline Diodogorgia nodulifera* & $\mathrm{x}$ & $\mathrm{x}$ & & $\mathrm{x}$ & $\mathrm{x}$ & $\mathrm{x}$ & $\mathrm{x}$ & \\
\hline Erythropodium caribaeorum & $\mathrm{x}$ & $\mathrm{x}$ & $\mathrm{x}$ & $\mathrm{x}$ & $\mathrm{x}$ & $\mathrm{x}$ & $\mathrm{x}$ & \\
\hline Iciliogorgia schrammi & & $x$ & $\mathrm{x}$ & $x$ & & $\mathrm{x}$ & $\mathrm{x}$ & \\
\hline \multicolumn{9}{|l|}{ Suborder Holaxonia } \\
\hline \multicolumn{9}{|l|}{ Family Plexauridae } \\
\hline Eunicea asperula & $x$ & $x$ & $x$ & $x$ & & & & \\
\hline E. calyculata & $x$ & $\mathrm{x}$ & $x$ & $x$ & & $x$ & $x$ & $\mathrm{x}$ \\
\hline Eunicea (=Plexaura) flexuosa* & $\mathrm{x}$ & $\mathrm{x}$ & $\mathrm{x}$ & $\mathrm{x}$ & & $\mathrm{x}$ & $\mathrm{x}$ & $\mathrm{x}$ \\
\hline E. fusca & & $\mathrm{x}$ & $\mathrm{x}$ & $x$ & & $\mathrm{x}$ & $\mathrm{x}$ & $x$ \\
\hline E. knighti & $x$ & $\mathrm{x}$ & $x$ & & $\mathrm{x}$ & & $x$ & $\mathrm{x}$ \\
\hline E. laciniata & $\mathrm{x}$ & $x$ & $\mathrm{x}$ & $x$ & & $x$ & $\mathrm{X}$ & \\
\hline E. mammosa & & $x$ & $x$ & & $\mathrm{x}$ & & $x$ & \\
\hline E. palmeri & & $\mathrm{x}$ & $x$ & & & & $\mathrm{x}$ & \\
\hline E. succinea & & $\mathrm{x}$ & $x$ & $x$ & $\mathrm{x}$ & & $x$ & \\
\hline E. tourneforti & $\mathrm{x}$ & $x$ & $x$ & $x$ & $\mathrm{x}$ & $x$ & $x$ & \\
\hline Muricea atlantica & $\mathrm{x}$ & $\hat{x}$ & $x$ & $x$ & & $x$ & $x$ & $\mathrm{x}$ \\
\hline M. elongata & $\mathrm{x}$ & $\mathrm{x}$ & $\mathrm{x}$ & $\mathrm{x}$ & $\mathrm{x}$ & & $\mathrm{x}$ & $\mathrm{x}$ \\
\hline M. laxa & $\mathrm{x}$ & $x$ & $\mathrm{x}$ & $\mathrm{x}$ & & $\mathrm{x}$ & $\mathrm{x}$ & $\mathrm{x}$ \\
\hline M. muricata & & $x$ & $\mathrm{x}$ & & $\mathrm{x}$ & & $\mathrm{x}$ & $\mathrm{x}$ \\
\hline \multicolumn{9}{|l|}{ M. pendula } \\
\hline \multicolumn{9}{|l|}{ M. pinnata } \\
\hline Muriceopsis flavida* & & $x$ & $x$ & $x$ & & $x$ & $x$ & \\
\hline M. petila & & $x$ & $x$ & & & $\mathrm{x}$ & & \\
\hline Plexaura kuna (=Plexaura A) & & $\mathrm{x}$ & & & & & & \\
\hline P. homomalla & & $x$ & $x$ & $\mathrm{x}$ & & $\mathrm{x}$ & $x$ & $\mathrm{x}$ \\
\hline Plexaurella dichotoma & & $x$ & $\mathrm{x}$ & $\mathrm{x}$ & & $\mathrm{x}$ & $\mathrm{x}$ & $\mathrm{x}$ \\
\hline P. fusifera & $\mathrm{x}$ & $\mathrm{x}$ & $\mathrm{x}$ & & $\mathrm{x}$ & & $\mathrm{x}$ & $\mathrm{x}$ \\
\hline P. grisea & & $\mathrm{x}$ & $\mathrm{x}$ & $\mathrm{x}$ & & $\mathrm{x}$ & $\mathrm{x}$ & \\
\hline P. nutans* & $\mathrm{x}$ & $x$ & $\mathrm{x}$ & $\mathrm{x}$ & & $\mathrm{x}$ & $\mathrm{x}$ & $\mathrm{x}$ \\
\hline P. pumila & & $\mathrm{x}$ & $\mathrm{x}$ & & & $\mathrm{x}$ & $\mathrm{x}$ & $\mathrm{x}$ \\
\hline Pseudoplexaura crucis & & $x$ & & $x$ & & $\mathrm{x}$ & $x$ & \\
\hline P. flagellosa & & $\mathrm{x}$ & $\mathrm{x}$ & $\mathrm{x}$ & & $\hat{x}$ & $\mathrm{x}$ & $\mathrm{x}$ \\
\hline P. porosa & & $\mathrm{x}$ & $\mathrm{x}$ & $\mathrm{x}$ & & $\mathrm{x}$ & $\mathrm{x}$ & $\mathrm{x}$ \\
\hline P. wagenaari & $\mathrm{x}$ & $\mathrm{x}$ & & $\mathrm{x}$ & & $\mathrm{x}$ & $\mathrm{x}$ & $\mathrm{x}$ \\
\hline Swiftia exserta* & & $\mathrm{x}$ & & & & $\hat{x}$ & & \\
\hline \multicolumn{9}{|l|}{ Family Gorgoniidae } \\
\hline Antillogorgia (=Pseudopterogorgia) acerosa* & $\mathrm{x}$ & $\mathrm{x}$ & $\mathrm{x}$ & $\mathrm{x}$ & $\mathrm{x}$ & $\mathrm{x}$ & $x$ & $\mathrm{x}$ \\
\hline A. americana & & $\mathrm{x}$ & $\mathrm{x}$ & $\mathrm{x}$ & $\mathrm{x}$ & $\mathrm{x}$ & $\mathrm{x}$ & $\mathrm{x}$ \\
\hline A. bipinnata & & $\mathrm{x}$ & $x$ & $x$ & $x$ & $\mathrm{x}$ & $x$ & \\
\hline A. elisabethae* & & $\mathrm{x}$ & $\mathrm{x}$ & & & $\mathrm{x}$ & $\mathrm{x}$ & \\
\hline A. kallos* & & $\mathrm{x}$ & & & & $\mathrm{x}$ & & \\
\hline A. rigida & $\mathrm{x}$ & $\hat{x}$ & $\mathrm{x}$ & $\mathrm{x}$ & $\mathrm{x}$ & $\hat{x}$ & $\mathrm{x}$ & \\
\hline Gorgonia flabellum & & $x$ & $\mathrm{x}$ & & $\mathrm{x}$ & $\mathrm{x}$ & $x$ & \\
\hline G. ventalina & & $x$ & $\mathrm{x}$ & $\mathrm{x}$ & & $\hat{x}$ & $x$ & $\mathrm{x}$ \\
\hline Leptogorgia (=Lophogorgia) cardinalis & $x$ & $x$ & & & & $x$ & $x$ & \\
\hline L. punicea & & & & & & & & \\
\hline L. virgulata & $\mathrm{x}$ & & & $\mathrm{x}$ & & & $\mathrm{x}$ & \\
\hline Pterogorgia anceps* & & $x$ & $\mathrm{x}$ & $x$ & & $\mathrm{x}$ & $x$ & \\
\hline P. citrina* ${ }^{*}$ & & $\mathrm{x}$ & $\mathrm{x}$ & $\hat{x}$ & & $\hat{x}$ & $\hat{x}$ & $\mathrm{x}$ \\
\hline P. guadalupensis & $x$ & $\hat{x}$ & & $\hat{x}$ & & $\hat{x}$ & $\hat{x}$ & \\
\hline \multicolumn{9}{|l|}{$\begin{array}{l}\text { Suborder Calcaxonia } \\
\text { Family Ellisellidae }\end{array}$} \\
\hline Ellisella barbadensis & $\mathrm{x}$ & $\mathrm{x}$ & & & $\mathrm{x}$ & $\mathrm{x}$ & $\mathrm{x}$ & \\
\hline E. elongata & & $x$ & $\mathrm{x}$ & & & & $\mathrm{X}$ & $\mathrm{x}$ \\
\hline Ellisella (=Nicella) schmitti & & $x$ & & & & & $x$ & \\
\hline
\end{tabular}

1(1) Gulf of Mexico, including the west coast of Florida, (2) southeastern Florida including the Florida Keys, (3) Bahamian archipelago (Bahamas and Turks and Caicos), (4) Hispaniola, Puerto Rico, U.S. Virgin Islands, (5) Antillean (Lesser Antilles from the British Virgin Islands to Barbados and Grenada), (6) NW Caribbean (Cuba, Jamaica, Cayman Islands, Caribbean coast of Mexico, and Belize), (7) Continental Caribbean (Honduras to Suriname, including Trinidad, Tobago, Aruba, Bonaire, and Curacao), and (8) Bermuda.

affect an organism's "schedule" of reproduction and survival; how an organism reproduces (including reproductive mode); timing of reproduction in relation to environmental factors, age, or size; frequency of reproduction (semalparity vs. iteroparity); type of larval output (internal brooding vs. external spawning and development); and number of offspring produced per reproductive episode. Life history also includes adaptations relating to an organism's interactions with other organisms.

Most marine populations, including octocorals, are dynamic in both space and time. Survival of adults is one of the principal factors affecting popula- 
tion changes. For example, if survival of adults is high, then the current population size plays a significant role in explaining the population size in the future. As many octocorals brood larvae, often throughout the year, once an assemblage of reproductive colonies is established, it tends to persist. At the same time, the generation of offspring and survival of young are also important.

\section{Age and Growth}

Growth rate data are limited for most octocoral species (Cary, 1914; Yoshioka and Yoshioka, 1991). Colony growth is usually estimated by changes in colony height. Like other modular organisms, such as stony corals, there is high variability in growth and size is often a poor indicator of colony age (Yoshioka and Yoshioka, 1991). In general, faster-growing octocoral species tend to be found at higher densities (Yoshioka, 1997). Previous studies suggest a general pattern of relatively low mortality and high variability in octocoral growth rates (Yoshioka and Yoshioka, 1991), with variability in growth roughly equivalent to average growth increments. Thinly branched taxa, such as Antillogorgia and Muricea species, can grow up to $4 \mathrm{~cm} / \mathrm{yr}$, while thicker branched species, such as Plexaurella, barely grow $1 \mathrm{~cm} / \mathrm{yr}$ (Yoshioka and Yoshioka, 1991). Birkeland (1974) recorded a mean growth of $2.6 \pm 1.9 \mathrm{~cm}$ (mean $\pm 95 \% \mathrm{CI}$ ) for the common sea fan, Gorgonia ventalina, over a 230-day period off coastal Panama. Birkeland (1974) recorded an annual growth rate of $2 \mathrm{~cm} / \mathrm{yr}$ for the same species in the Cayman Islands. Yoshioka and Yoshioka (1991) studied a multi-species octocoral assemblage on two shallow-water reefs $(<$ $10 \mathrm{~m}$ ) off the southwest coast of Puerto Rico over a 4.5-yr period. Growth rates, as determined by changes in colony heights, ranged from $0.8-4.5 \mathrm{~cm} /$ yr among 12 taxa. The mean growth rate was $1.4-2.6 \mathrm{~cm} / \mathrm{yr}$ for most species, ranging from a low $0.8 \mathrm{~cm} / \mathrm{yr}$ in Plexaurella dichotoma to a high of 4.5 $\mathrm{cm} / \mathrm{yr}$ in Antillogorgia americana. Uninjured colonies generally grew faster than injured colonies, thus sublethal injuries were concluded to be partly responsible for intra-specific variation in growth (Yoshioka and Yoshioka, 1991). Thinly branched species ( $A$. acerosa and A. americana) are relatively fast growing, while species with thicker branches (e.g., $P$. dichotoma) grow slower, presumably representing a trade-off between colony branch elongation and branch thickening (Yoshioka and Yoshioka, 1991).

\section{Reproduction and Recruitment}

Like many marine invertebrates, octocorals exhibit a two-stage (bi-partite) life cycle, consisting of a benthic, sessile stage (post-settlement juvenile to adulthood) and a planktonic larval stage (planula). The oval-shaped, featureless planula larvae settle out from the water column, with the spatial pattern of settlement influenced by substratum type, light intensity, and integrity (Wahle, 1985). Crustose coralline algae are preferred substrate for octocoral recruitment (Benayahu et al., 1989; Lasker and Kim, 1996). In contrast, the presence of algal films or sediment can impede recruitment and/ or lead to greater post-settlement mortality (Gotelli, 1988). Upon settlement, the planula larvae metamorphose into a founder polyp, initially forming a short stalk at one end that is attached to the substratum. The other polyp end flattens and eight tentacle buds develop around the mouth opening (Fabricius and Alderslade, 2001). Within a few days, a complete octocoral polyp develops; at this stage, some zooxanthellae species begin to take in planktonic zooxanthellae through the mouth (the zooxanthellae are not digested, but are incorporated into the octocoral tissue), while in other species, the larva are supplied with zooxanthellae prior to their release into the water column (Benayahu et al., 1992). Although a few deeper water octocoral taxa remain permanently solitary as single polyps, all other octocorals develop from a solitary founder polyp and form colonies derived from budding (Fabricius and Alderslade, 2001).

Octocorals typically reach sexual maturity when colonies are over 20 $\mathrm{cm}$ in height. Pterogorgia citrina, a small bushy octocoral that rarely grows above $30 \mathrm{~cm}$ in height, may reach sexual maturity sooner, but little is known about this species. To provide adequately sized octocorals to home aquarists, collectors typically take colonies that are less than $20 \mathrm{~cm}$ in height. In doing so, collectors leave larger colonies behind that are the major contributors of gametes to the population. For example, colonies of Eunicea flexuosa over $70 \mathrm{~cm}$ in height produce 93-98\% of the eggs released during spawning (Beiring and Lasker, 2000). The octocoral collectors interviewed indicated that they rotate collection sites and are selective in which colonies they collect.

Asexual reproduction is common in octocorals (Fabricius and Alderslade, 2001) and often the predominant mode of reproduction, but not in all species (e.g., Leptogorgia virgulata, Gotelli, 1988). In asexual reproduction, colonies may form runners or stolons from the base of the colony, or extend branches out from the colony. The parent colony then translocates parts of its own body mass through the stolon, and a new daughter colony forms that separates from the parent. The stolon is then resorbed, resulting in two colonies. Octocorals also can bud, fragment, and undergo colony fission, where constrictions are formed in the colony and eventually divide into two independent smaller colonies. In budding, small buds are produced on the edge or base of a colony, which eventually drop off and attach to the substratum as separate colonies. Some species are known to drop polyp bundles consisting of 5-10 polyps that sink to the substratum, or by "autonomy of colony ends" (i.e., fragmentation sensu Walker and Bull, 1983).

Octocorals sexually reproduce using a diversity of strategies paralleling scleractinian reef-building corals (Kahng et al., 2011). Most octocorals have male and female reproductive structures in separate colonies, which is referred to as the gonochoristic mode of reproduction (Fabricius and 
Alderslade, 2001). Three types of sexual reproduction have been identified in octocorals: broadcasting (broadcast spawning) of eggs and sperm, internal brooding of larvae, and external brooding of larvae (Benayahu and Loya, 1984; Benayahu, 1991; Lasker and Stewart, 1992). Broadcast spawning has been observed in alcyoniid soft corals and some gorgonians, which release large numbers of eggs and sperm into the water where external fertilization occurs. Spawning is often synchronized according to lunar phase and/or water temperature. Subsequently, planula larvae develop from fertilized eggs and remain in the plankton for days to weeks until settlement and metamorphosis into founder polyps. Larvae may be carried a considerable distance - tens to hundreds of $\mathrm{km}$ away from the parental colonies based upon oceanographic conditions (Gotelli, 1988). Some species (i.e., Plexaura kuna and Eunicea fusca) exhibit multiple strategies, reproducing sexually (brooding or broadcast spawning) and asexually through fragmentation and vegetative propagation (Kahng et al., 2011), which can support high population growth rates (Lasker, 1988).

Like scleractinian corals, the demography of octocorals, including sexual maturity and reproductive output, may be more based upon size (height) rather than age (Wahle, 1983; Kapela and Lasker, 1999). Octocorals have size-dependent reproduction ability, although some (e.g., Leptogorgia virgulata) may be reproductively competent within two years of settlement (Gotelli, 1988), while other taxa may not reach reproductive competence until much later post-settlement (Beiring and Lasker, 2000).

Internal brooding of larvae is common in many gonochoristic octocorals (e.g., family Xeniidae), including some taxa in the wider Caribbean (Brazeau and Lasker, 1990). Sperm are released into the water (not the eggs), usually a few hours after sunset, and the eggs that are fertilized develop into larvae within the female colonies. Larvae are released days to weeks later and are ready or nearly so for metamorphosis. A final reproductive strategy within the octocorals is the external brooding of larvae. The fertilized eggs develop into larvae within mucus pouches on the surfaces of the mother colonies (Brazeau and Lasker, 1990). Brooded larvae, which are negatively buoyant, may settle within a few meters of the mother colony.

Existing information on octocoral recruitment and post-settlement mortality suggests that, in contrast to established adult colonies, post-settlement mortality can be quite high. For example, Gotelli (1988) observed that $\sim 64 \%$ of Leptogorgia virgulata recruits did not survive the first year after settlement. With established populations, survival of additional post-settlement octocoral recruits is generally higher, while survival of established, larger colonies (10+ $\mathrm{cm}$ in height) may be more or less constant ( $94 \%$ per yr) (Yoshioka, 1998). While established colonies may or may not be a key factor underlying octocoral population fluctuations, they are essential to the persistence of populations (Yoshioka, 1998).

\section{Mortality Rates, Sources \\ of Mortality, and \\ Regeneration from Injury}

Lacking major disturbances, such as storms and disease outbreaks, octocorals appear to exhibit low mortality rates from the few studies available. Over a 230-day period off the coast of Panama, for example, Birkeland (1974) documented > 95\% survivorship of sea fans (Gorgonia ventalina). Probably the most comprehensive study of survivorship rates in a multispecies octocoral assemblage is the work of Yoshioka and Yoshioka (1991). At two sites on the southwestern coast of Puerto Rico, they recorded an annualized survivorship rate of 91.6$92.4 \%$, with no significant differences among the 12 octocoral taxa sampled. Sublethal (i.e., not whole colony) injuries were responsible for some of the high intra-specific variation in growth; uninjured colonies generally grow faster than injured colonies (Yoshioka and Yoshioka, 1991).

Sources of octocoral mortality include detachment from the substratum (Wahle, 1985), fracture of the skeleton, overgrowth (Wahle, 1980), disease outbreaks (Naglelkerken et al., 1997), and thermal stress (Lasker, 2005). Octocorals are susceptible to abrasion and dislodgement by storm waves and associated movement of sand and rubble (Wahle, 1985; Fabricius and Alderslade, 2001). Some Caribbean octocorals (e.g., encrusting Briareum and Erythropodium), along with some branching species, especially sea fans (Gorgonia spp.), are quite abundant in wave-exposed environments. However, many octocorals are more abundant in less wave-exposed environments, including lagoon patch reefs and deeper fore-reef habitats ( $\mathrm{Fa}-$ bricius and Alderslade, 2001). In shallower water, sea fan colony orientation is perpendicular to current direction (Wainwright and Dillon, 1969), presumably an adaptation to high waveenergy conditions and to maximize food particle interception.

Sediment burial and abrasion stress are important sources of mortality for both established colonies and newly settled recruits (Gotelli, 1988), along with weakening of the substratum (Yoshioka and Yoshioka, 1991). Colony detachment generally results from the failure of the underlying substrate rather than the colony holdfast (Cary, 1914; Kinzie, 1973; Birkeland, 1974). The major source of mortality (40-71\%) in one study (Yoshioka and Yoshioka, 1991) was due to basal fracture (breakage of the axial skeleton near the colony base (22-46\%) where greater rates were attributed to higher wave energy. Injury to the colony basal tissue caused by physical abrasion increases the probability that a colony will eventually experience basal fracture (Yoshioka and Yoshioka, 1991). Detachment and basal fracture are largely non-selective among octocoral species and are not likely due to predation (Harvell and Suchaneck, 1987; Lasker and Coffroth, 1983; Yoshioka and Yoshioka, 1991). 


\section{Ecological and Economic Roles of Octocorals}

Most octocorals are suspension feeders, obtaining small food particles from the water column. The octocoral diet consists of small $(<20 \mu \mathrm{m})$ particulate organic matter such as bacteria, phytoplankton cells, and zooplankton (Fabricius and Klumpp, 1995; Fabricius et al., 1995; Ribes et al., 1998). Most of the food captured is assimilated near the point of ingestion (Murdoch, 1978). Larger particles that encounter tentacles are captured and swallowed if suitable, typically consisting of early crustacean and bivalve larval stages (Fabricius et al., 1995; Ribes et al., 1998). As octocoral nematocysts are relatively small compared to jellies, hydroids, and sea anemones (Fabricius and Alderslade, 2001), particle capture is restricted to smaller food items. The octocoral epidermis is covered with microvilli, so absorption of dissolved organic matter is likely an additional food source (Schlichter, 1982). Octocoral feeding rates are affected by food concentrations and currents (Fabricius et al., 1995).

Azooxanthellate octocorals, because they do not harbor zooxanthellae, obtain all of their nutrition by suspension feeding. Many shallow-water octocorals host symbiotic algae (zooxanthellae, Dinoflagellata) to supplement their dietary needs and are thus light dependent (Kinzie, 1973). Zooxanthellae are embedded in gastrodermal cells or in membrane-bound vacuoles within the gastrovascular cavity. Zooxanthellate octocorals utilize photosynthetic products from their microalgae to contribute to their energy needs, but still must rely upon particle capture by the tentacles (Fabricius and Klumpp, 1995). Octocorals apparently have a lower photosynthetic efficiency that may be related to the low surface area of octocoral colonies in relation to biomass (i.e., photosynthetic yields are low and respiration rates are relatively high) (Fabricius and Alderslade, 2001). Most zooxanthellate octocorals generally expand their tentacles and feed during the day, yet some species have a reverse pattern, possibly due to strong or slack current flow, high irradiance, and/or disturbance by predators (Fabricius and Alderslade, 2001). Preston and Preston (1975) found that the degree of polyp extension in an assemblage of mostly zooxanthellate octocorals was related to plankton availability, but light intensity was most important in daily activity patterns.

Because branching octocorals grow upright from the substratum, they offer a canopy structure that provides habitat for a diversity of invertebrates and fishes (Cairns, 1977; Wahle, 1980). Patton (1972) documented animal symbionts on Leptogorgia virgulata from the northern Gulf of Mexico, while Spotte and Bubucis (1996) described the caridean shrimps associated with Antillogorgia americana.

From the information compiled on octocorals as represented in the Appendix, it is clear that many information gaps exist, particularly growth, age, longevity, mode of reproduction, and recruitment rates for deeper-water taxa. There are relatively few longterm studies of growth and survivorship (Yoshioka and Yoshioka, 1991), and most studies of octocoral species or assemblages have been short in duration $(<1 \mathrm{yr})$ and usually limited to one or a few species (Yoshioka and Yoshioka, 1991).

\section{Analysis of Current Data Collection Programs}

Current data collection programs for octocoral management in the U.S. South Atlantic and Gulf of Mexico were reviewed as part of this study, particularly fishery independent studies in southeast Florida and the Florida Keys, since most octocorals are landed from these areas. The narrative below, along with the management recommendations section, addresses the following questions raised about the U.S. South Atlantic octocoral fishery. First, is the level of data collected at the State of Florida and Federal levels sufficient to effectively manage the octocoral fishery? Second, does existing information on octocoral abundance and distribution lead to a better understanding of the octocoral fishery and potential management improvements or alternatives? Next, is the current octocoral fishery reporting structure sufficient, or are there changes to implement that would improve management or understanding of the fishery? Relatedly, is there a need for an octocoral species identification guide to help standardize reporting requirements in the U.S. South Atlantic? Finally, what fishery-independent assessment and monitoring data are available for octocorals in the region that provide octocoral populationlevel assessments? Are these efforts adequate to assess the status of populations using current data from the octocoral fishery?

The marine aquarium trade has both commercial and recreational components, and similar to other fisheries, is complex in terms of the diversity and number of invertebrate and fish species targeted, the different types of gear and approaches used to capture organisms, geographic areas, and access points (Bohnsack et al., 1994). There is a long history of marine life collection that dates back to at least the 1960s in the south Florida area, where a diversity of invertebrate and fishes were collected, primarily for the marine aquarium industry but also for the curio trade (Voss et al., 1969; Jaap and Wheaton, 1975; Robins, 1976; Derr, 1992; Bohnsack et al., 1994). Some of these activities are now managed, including the moratorium on sea fan collection, restrictions on live rock collection, and prohibitions on the use of chemicals for collecting (FAC Chap. 68B-42). In Florida waters, the collection of live tropical, ornamental, and marine species such as fish, invertebrates, and plants is regulated by FAC Chap. 68B-42. Implementation of the "Marine Life Rule" went into effect in 1991 and has undergone subsequent amendments. Bag limits, collection techniques, and area restrictions have been set for recreational and commercial marine life collectors in both Federal and Florida waters, and included restricted collection of certain species 
and licensing and endorsement requirements. Octocorals are currently considered to be ornamental species. Historical (Bohnsack et al., 1994) and current collection levels (FWC, 2014), in terms of numbers of individuals or colonies removed, are lower than for most other marine life fishery species and groups (Table 4).

The historical and current reporting structure for the Florida marine life fishery dating back to 1990 consists of landings by numbers of individuals or colonies, as opposed to the sizes and/or weights of organisms captured (Bohnsack et al., 1994; FWC, 2014). Exceptions to this pattern are for marine plants (weight) and live rock (weight or number of boxes) when this was permitted. Since 1990, octocoral landings, which are reported as the number of colonies collected, are grouped into broad categories based on color (e.g., yellow, purple, or red), growth form (e.g., sea blades), or other (Bohnsack et al., 1994; FWC, 2014). In Florida, landings were initially reported from the county where an organism was first sold, not necessarily where an organism was collected. The FWC currently collects octocoral data in terms of numbers of colonies collected, number of collection trips, average price per colony, and average dockside value of colonies. On both the Florida Atlantic Ocean and Gulf of Mexico coasts, information gathered from octocoral collectors indicates that among these color groupings, there are at least 29 octocoral species among 19 genera, with at least 12 nominal taxa (species and/or genera) characterized as in high demand (Tables 1 and 2).

There are aspects of octocoral biology and ecology that are relatively similar across taxa, such as the need for stable hard substrata for settlement and growth. On the other hand, some species exhibit differences in habitat distribution and life history parameters such as growth rate and reproduction. For many of the targeted taxa, there is a paucity of available information on habitat distribution, population abundance, and life history parameters, especially for species that have deeper depth distributions (e.g., Diodogorgia, Ellisella, Iciliogorgia, and Swiftia). These taxa are under-sampled or are not targeted in historical and current assessment and monitoring programs. Despite these constraints, there is evidence that even some of the deeper water octocorals are broadly distributed and occur in high densities along much of the southeastern coast of the U.S. $\left(\right.$ David $\left.^{10}\right)$. There are obvious gaps in knowledge related to the distribution and abundance of some octocoral genera and species. However, the relatively broad distribution of most octocorals in southeastern Florida and estimates of current population sizes presented below, relative to the small numbers of octocorals collected per year for most taxa, suggests that 1) additional reporting requirements, while desirable, may not be necessary, and 2) the octocoral fishery in Florida is sustainable. The number of octocorals collected in Florida appears to be a minor percentage $(<0.1 \%)$ of the population abundance estimates, where they exist, for aggregate and individual taxa.

\section{Fishery Independent Data Sources}

Fishery-independent assessment and monitoring available for octocorals in the U.S. South Atlantic and Gulf of Mexico regions are described below, with a focus on results that provide population-level assessments for octocorals. Results address whether or not these data are adequate to assess the status of octocoral populations in the absence of finer-resolution fishery-dependent data from the octocoral fishery. As most octocorals are collected in southeastern Florida from Palm Beach County to Monroe County (Table 5), the focus of this section provides an overview of historical and current studies of octocorals in the area. Sampling efforts are briefly reviewed that provide data on geographic distribution, habitat and depth distribution,

\footnotetext{
${ }^{10}$ David, Andrew. NOAA Natl. Mar. Fish. Serv.,
}

colony density, colony size structure, and population abundance estimates.

For the southeastern Florida and Florida Keys areas, the available information on octocoral population parameters (distribution, density, size structure, and abundance estimates) can be summarized as follows. First, most surveys of octocorals were conducted in relatively shallow-water $(<15 \mathrm{~m})$ hard-bottom and coral reef habitats, although a few studies surveyed deeper hard-bottom and reef environments (e.g., Goldberg, 1973; Wheaton, 1981, 1987). Second, most historical studies conducted species inventories of octocorals in one or more habitats, with information presented as species presence or absence (e.g., Voss and Voss, 1955; Voss et al., 1969; Davis, 1982; Wheaton, 1987; reviewed in Levy et al., 1996). Third, relatively few historical and more recent studies have quantified octocoral colony density (numbers of colonies per unit area) by habitat and depth (e.g., Goldberg, 1973; Opresko, 1973; Kissling, 1977; Jaap, 1984; Wheaton and Jaap, 1988; Chiappone and Sullivan, 1994), and these studies have typically been of limited duration $(<2 \mathrm{yr})$. A few sampling efforts provide estimates of octocoral holdfast or canopy cover, but, except for encrusting species, they do not provide information on octocoral densities (Chiappone and Sullivan, 1997; Ruzicka et al., 2009; Gilliam, 2012). Even fewer studies recorded octocoral size (height) structure for branching octocorals species (e.g., Opresko, 1973). A small number of projects such as the Coral Reef Evaluation and Monitoring Program (CREMP), Broward County's Marine Biological Monitoring Program, and local academic institutions, through the use of permanently marked sampling locations, have monitored changes in octocoral canopy cover and/ or colony densities either annually or intermittently, dating back in some cases to the mid-1990s (Blair and Flynn, 1989; Moyer et al., 2003; Beaver et al., 2006; FWC, 2006; Thanner et al., 2006; Gilliam et al., 2007). Finally, only one program to our knowledge has used a survey sampling design, structured 
by habitat, depth, geographic region, and management zone, to quantify octocoral densities that can be scaled to abundance estimates (Miller et al., 2002; Smith et al., 2011).

The majority of available information on octocorals in Florida consists of species lists or inventories from various studies, dating back to the 1950s (e.g., Bayer, 1961), combined with information on habitat and depth distribution (reviewed in Levy et al., 1996). These surveys were usually conducted within a proposed or existing protected area such as: Biscayne National Monument (now Biscayne National Park) (Voss et al., 1969; Jaap, 1984), Ft. Jefferson National Monument (now Dry Tortugas National Park) (Davis, 1982), Key Largo National Marine Sanctuary (now the Key Largo Management Area), Looe Key National Marine Sanctuary (now the Looe Key Management Area) (Antonius et al., 1978; Wheaton and Jaap, 1988), and Florida state parks (John Pennekamp Coral Reef State Park). Most historical octocoral studies report species occurrences related to benthic habitat types; these data are largely captured in the life history summaries in the Appendix. In other instances, taxonomic or field guides provide more general geographic distribution patterns (e.g., Bayer, 1961; Cairns, 1977; Colin, 1978). With few exceptions, species inventories were usually in shallow-water $(<15 \mathrm{~m})$ hard-bottom and reef habitats. In the early 1970s, however, Goldberg (1973) conducted stony coral and octocoral surveys to $44 \mathrm{~m}$ depth off Palm Beach County (described below). In 1975, Wheaton (1981) conducted qualitative surveys (species identification and photographs) at Carysfort Reef in the upper Florida Keys using replicate belt transects sampled to $21 \mathrm{~m}$ depth and recorded 27 taxa. Additional visual surveys of octocorals using a submersible were conducted in 1979 at French Reef, Elbow Reef, and Carysfort Reef within the Key Largo Coral Reef Marine Sanctuary at depths of 27-56 m (Wheaton, 1987).

Further north along the southeastern Florida reef tract from Miami-
Dade to Palm Beach Counties, Banks et al. (2008) summarized several studies describing hard-bottom and reef community structure (Goldberg et al., 1973; Blair and Flynn, 1989; Moyer et al., 2003; Beaver et al., 2006; FWC, 2006; Thanner et al., 2006; Gilliam et al., 2007). Historical surveys of octocorals north of the Florida Keys are somewhat limited. Goldberg (1973) conducted benthic surveys of stony corals and octocorals on nearshore patch reefs ( $9 \mathrm{~m}$ depth), the outer reef from $16-30 \mathrm{~m}$ depth, and the fore reef (32-44 $\mathrm{m}$ depth) off Boca Raton, Florida. Octocoral diversity (39 species) and densities were high (25 colonies $/ \mathrm{m}^{2}$ ). The greatest octocoral diversity occurred on the outer reef where the convergence of shallow and deepwater octocorals occurs from 15-30 m depth. Faunal cover for some habitats is similar to that further south in the Florida Keys, with hard-bottom areas often dominated by octocorals and sponges. Octocorals in the genera Eunicea and Muricea, along with Briareum asbestinum, are the dominant taxa from the 48 species reported. Based on averages of data collected by Blair and Flynn (1989), Thanner et al. (2006), and Gilliam et al. (2007), octocoral density throughout the southeastern Florida reef tract is approximately 7.7 colonies $/ \mathrm{m}^{2}$. Some areas in Palm Beach County have densities of more than 30 octocoral colonies per $\mathrm{m}^{2}$ (Gilliam et al., 2003), while hard-bottom habitats off Miami-Dade County have octocoral densities between 2.9-21.2 colonies/ $\mathrm{m}^{2}$ (Blair and Flynn, 1989).

Broward County's Marine Biological Monitoring Program monitors the status and trends of coral and hardbottom communities. Since 1997, the Broward County Department of Planning and Environmental Protection and the National Coral Reef Institute at Nova Southeastern University have quantified octocoral densities along belt photo-transects at 25 permanent sites on the nearshore and offshore reef terraces (Gilliam et al., 2004a). At these sites, octocoral density was $8.9 \pm 13.9$ colonies $/ \mathrm{m}^{2}$ and as high as
30 colonies $/ \mathrm{m}^{2}$ (Gilliam et al., 2003; Sathe et al., 2008).

Further south in the Florida Keys, several historical surveys provide octocoral distribution and density data from nearshore hard-bottom and patch reef environments (Voss and Voss, 1955; Opresko, 1973; Chiappone and Sullivan, 1994). Chiappone and Sullivan (1994) conducted presence-absence and density surveys of stony corals and octocorals at several nearshore hard-bottom and patch reef sites in the middle Florida Keys. Average octocoral densities ranged from 0.02-4.3 colonies $/ \mathrm{m}^{2}$, with the lowest species richness and colony densities on either nearshore hard-bottom habitat in Florida Bay, or on patch reefs dominated by massive corals. On the Atlantic Oceanside, hard bottom habitat exposed to moderately strong tidal flow was dominated by the genera $\mathrm{Eu}$ nicea, Pseudoplexaura, and Briareum.

On Florida Keys patch reefs, historical surveys, mostly from Biscayne National Park (BNP), as reported by Opresko (1973), Jaap and Wheaton ${ }^{11}$, and Jaap (1984), show variable octocoral densities ranging from 6.9-46.8 colonies $/ \mathrm{m}^{2}$. Antillogorgia americana, Briareum asbestinum, Eunicea flexuosa, E. succinea, Gorgonia ventali$n a$, and Plexaura homomalla were the most dominant among 29 species present (Opresko, 1973). Wheaton (unpubl. data as reported in Wheaton and Jaap (1988)) observed 31 species in similar habitats in the Biscayne $\mathrm{Na}$ tional Park area during surveys conducted over five years. In hard-bottom areas of Biscayne National Park, including nearshore tidal passes, beneath bridges, and seaward of the intertidal zone, octocoral densities were 38.3 colonies $/ \mathrm{m}^{2}$ and on transitional bank reefs, densities were 25.2 colonies $/ \mathrm{m}^{2}$ (Jaap, 1984).

Surveys conducted at six sites within Looe Key National Marine Sanctu-

\footnotetext{
${ }^{11}$ Jaap, W. C., and J. L. Wheaton. 1977. Unpublished report to the National Park Service on coral research in Biscayne National Monument. Cited In J. Dupont, W. Jaap, and P. Hallock. 2008 A retrospective analysis and comparative study of stony coral assemblages in Biscayne National Park, FL (1977-2000). Carib. J. Sci. 44:334-344.
} 
ary reported mean octocoral densities ranging from 1.1-20.6 colonies $/ \mathrm{m}^{2}$ (Wheaton and Jaap, 1988). Of the 23 octocoral species observed, Eunicea flexuosa, E. succinea, and Plexaura homomalla comprised nearly $55 \%$ of the octocoral fauna. Additional species recorded in relatively high densities were Antillogorgia americana, Gorgonia ventalina, and Muricea atlantica (Wheaton and Jaap, 1988).

The CREMP, spearheaded by the Florida Fish and Wildlife Research Institute, has monitored the status and trends of 37 sites in the Florida Keys National Marine Sanctuary (FKNMS) since 1995 (Ruzicka et al., 2009) and in 2012 added an octocoral demographic survey component at a subset of sites from the upper Keys to the Dry Tortugas. In 2003, additional sites were added in Miami-Dade, Broward, and Palm Beach Counties as part of the Southeast Florida CREMP (SECREMP). This effort currently encompasses 17 sites (Gilliam et al., 2004b). Using video and still photography, benthic cover is assessed by identifying the major functional cover groups (macroalgae, sponges, stony corals, and octocorals) within replicate belt transects. Benthic cover by octocorals is similar throughout the Florida Reef Tract from Palm Beach County to the Dry Tortugas (Gilliam, 2012). Percentage cover by octocorals increased significantly since 2010 in parts of Miami-Dade County $(12.8 \%$ in 2010 vs. $19.7 \%$ in 2011) and Broward County (5.4\% in 2010 vs. $7.6 \%$ in 2011). In Palm Beach County, however, sites within each of the three reef tracts have shown a decrease in octocoral cover since the project's inception. Gilliam (2012) reported that several Palm Beach County study sites buried by sand, possibly from beach renourishment activities and/or storm events, may have contributed to the decreased octocoral cover.

\section{Geographic Distribution and Density Patterns in the Florida Keys}

From 1999-2014, the Sanctuary Coral Reef Evaluation and Assess- ment Monitoring (SCREAM) program conducted benthic surveys of algae, sponges, and cnidarians, including octocorals, in a broad range of hard-bottom and coral reef habitats from the northern extent of Biscayne National Park to the Dry Tortugas (Miller et al., 2002; Smith et al., 2011). Originally designed to document the status and trends of no-take management zones throughout the FKNMS, the program expanded to include multiple habitats from nearshore patch reefs to the deeper reef slope. By broadly sampling populations among multiple habitat types across the south Florida shelf, inside and outside of the no-take management zones, and throughout the Florida Keys from south of Miami to the Dry Tortugas, over a 15-yr period (including 2014 surveys of octocorals), this effort documented the distribution, abundance, and changes over time of coral reef organisms and communities in the region. In the section below, data are summarized related to octocoral surveys, including recently conducted surveys during June-October 2014. The surveys provide information on distribution, density, and population abundance estimates of Florida Keys octocorals.

The survey sample design is described in Smith et al. (2011) and parallels efforts for reef fish surveys in the south Florida region since the late 1990s. For octocorals, data have been collected on species presence-absence, colony densities, and colony heights. Briefly, a geographic information system (GIS) containing digital layers for benthic habitat, bathymetry, and management zone boundaries in the Florida Keys is used to facilitate delineation of the Florida Keys study area. Existing resolution of benthic habitat mapping is such that the survey domain was divided into a grid of individual cells 200 $\mathrm{m} \times 200 \mathrm{~m}\left(40,000 \mathrm{~m}^{2}\right)$ that serve as primary sampling units. A two-stage sampling scheme was adapted (Smith et al., 2011) following Cochran (1977) and is employed to control for spatial variation in population metrics at scales smaller than the grid cell minimum mapping unit. Grid cells con- taining targeted reef and hard-bottom habitats are the primary sample units. A second-stage sample unit is defined as a belt transect of fixed area within a primary sample unit. The size of an individual primary sampling unit allowed divers to swim to the location of any given second-stage sampling unit from a moored or anchored vessel. During 1999-2004, octocorals were surveyed for colony densities in replicate $25 \mathrm{~m}$ x $0.4 \mathrm{~m}$ belt transects. From 2005-14, the belt transect survey area was reduced to replicate $8 \mathrm{~m} \times 1 \mathrm{~m}$ samples per site based upon results from previous surveys that indicated slightly smaller sample sizes were sufficient to maintain targeted variance (measured as coefficient of variation). Within belt transect areas, octocorals are identified to the lowest taxonomic level possible (usually to the species level) and colonies (ramets) are counted. All visual surveys are conducted using SCUBA, pre-formatted data slates, pencils, and rulers. Results are transcribed the same day into a database to help facilitate quality control and quality assurance.

To control for spatial variation in the benthic variables assessed, the Florida Keys survey domain was partitioned into strata based upon: 1) habitat type and depth, 2) geographic region (along-shelf position), and 3) management zones comprising Biscayne National Park (BNP), areas outside of Florida Keys National Marine Sanctuary no-take zones, and Sanctuary notake zones. Grid cells (sites) $200 \mathrm{~m} \mathrm{x}$ $200 \mathrm{~m}$ in dimension are randomly selected from the combination of habitat type, regional sector, and management zone factors. Habitats are designated using regional benthic habitat maps. The habitat classification scheme accounts for features that correlate with benthic faunal distributions, including cross-shelf position, topographic complexity, and the proportion of sand interspersed among hard-bottom structures. A geographic regional stratification variable (i.e., upper, middle, and lower Florida Keys) was used to account for oceanographic and geological features in the Florida Keys that influence the distribution and com- 
Table 8.-Sampling effort for octocorals in the upper Florida Keys from northern Key Largo to Upper Matecumbe Key during June-October 2014. The number of sites available represents the number of $200 \mathrm{~m} \mathrm{x} 200 \mathrm{~m}$ mapping grid cells based upon existing habitat mapping and bathymetry data. Two $8 \mathrm{~m} \times 1 \mathrm{~m}$ belt transects were surveyed for octocoral densities and colony sizes.

\begin{tabular}{lcccc}
\hline Benthic habitat type & $\begin{array}{c}\text { No. sites } \\
\text { available }\end{array}$ & $\begin{array}{c}\text { Habitat area } \\
\left(\mathrm{m}^{2}\right)\end{array}$ & $\begin{array}{c}\text { No. sites } \\
\text { sampled }\end{array}$ & $\begin{array}{c}\text { Area sampled } \\
\left(\mathrm{m}^{2}\right)\end{array}$ \\
\hline Inshore patch reefs & 2 & 80,000 & 2 & 32 \\
Mid-channel patch reefs & 622 & $24,880,000$ & 17 & 272 \\
Offshore patch reefs & 940 & $37,600,000$ & 26 & 416 \\
Back-reef rubble & 62 & $2,480,000$ & 7 & 112 \\
Inner line reef tract & 97 & $3,880,000$ & 11 & 176 \\
High-relief spur and groove & 111 & $4,440,000$ & 16 & 256 \\
Low-relief hard-bottom (<6 m) & 513 & $20,520,000$ & 3 & 48 \\
Low-relief spur and groove (6-15 m) & 367 & $14,680,000$ & 10 & 160 \\
Low-relief hard-bottom (6-15 m) & 480 & $19,200,000$ & 4 & 64 \\
Patchy hard-bottom (6-15 m) & 98 & $3,920,000$ & 6 & 96 \\
Total & 3,292 & $131,680,000$ & 102 & 1,632 \\
\hline
\end{tabular}

munity composition of hard-bottom and reef habitats. Management zones are incorporated as a third stratification variable that delineates areas open and closed to consumptive activities. The power of the stratified random sampling approach is two-fold: 1) the habitats comprising the most area are initially allocated more sites than those with less area (i.e., a proportional design); and 2) habitats exhibiting more variability with respect to particular metrics (e.g., coral species richness, octocoral density) are allocated more sites than those with less variability.

The habitats sampled during 19992014 incorporate most of the hardbottom and coral reef habitat types from the island platform (e.g., inshore patch reefs such as Tavernier Rocks) inshore of Hawk Channel to $\sim 15 \mathrm{~m}$ depth along the Florida Keys, including the Dry Tortugas. Benthic habitats surveyed for octocorals include inshore patch reefs, mid-channel patch reefs, offshore patch reefs, reef rubble, shallow $(<6 \mathrm{~m})$ hardbottom, shallow $(<6 \mathrm{~m})$ spur and groove, and deeper fore-reef habitats (low-relief spur and groove, consolidated hard-bottom, patchy hard-bottom) from 6-15 m depth. In certain years, deeper habitats were sampled to $27 \mathrm{~m}$ depth. The underwater surveys occurred at randomly selected, pre-determined coordinates, located with a differential global positioning system. If the original waypoint was not the intended habitat type, based on visual assessment by a snorkeler or boat observers, the closest alter- nate site was sampled instead. Once on-site, a two- or three-person dive team deployed two transect tapes. For octocorals, an $8 \mathrm{~m} \times 1 \mathrm{~m}$ belt area was surveyed along two transects.

Statistical analyses using this twostage sampling design are based upon Cochran (1977) and Smith et al. (2011). Density and abundance calculations are based upon the number of organisms recorded within the belt transect stations. First, density (no. of octocoral colonies $/ \mathrm{m}^{2}$ ) is calculated for each transect. Next, mean density and variance are calculated for each site, using the densities of the two stations. The mean site-level densities and variances are then used to calculate mean stratum-level (habitat, management zones, and habitat by management zone) densities and variances. Finally, stratum-level and domain abundance estimates are calculated based upon the stratum-level densities and variances, as well as the proportional areas of each stratum within the domain (Smith et al., 2011).

Octocoral survey data (species richness, octocoral densities, and in some cases colony heights) from this program were derived from the following efforts from 1999-2014:

- 1999: 80 sites from northern Key Largo to Key West and 23 additional sites in the Dry Tortugas;

- 2000: 45 sites from Big Pine Key to Key West and 36 additional sites in the Dry Tortugas;

- 2001: 86 sites from northern Key Largo to Key West;
- 2005: 195 sites from northern Biscayne National Park to Key West;

- 2006: 46 sites in the Dry Tortugas;

- 2008: 145 sites from northern Key Largo to Key West and 43 additional sites in the Dry Tortugas;

- 2009: 160 sites from northern Key Largo to Key West; and

- 2014: 102 sites from northern Key Largo to Upper Matecumbe Key (see Table 8).

Data presented in this section represents a small proportion of the overall sampling effort, but illustrate three important aspects of octocorals in the Florida Keys, with a particular focus on those taxa (species, genera, and color groups) targeted by the octocoral fishery. First, most octocoral taxa (genera and species) are broadly distributed on the south Florida shelf. The availability of hard substratum appears to be one of the most important factors affecting the spatial distribution of octocorals. Second, changes in octocoral densities from 1999-2014 indicate either no significant temporal patterns or increases for many taxa. Finally, population abundance estimates, integrating density estimates with habitat area, indicate that octocoral populations are either stable or have increased during the past 15 years. Population sizes for many taxa are quite large (tens to hundreds of millions of colonies).

It is noteworthy that this sampling program does not specifically target nearshore hard-bottom or seagrass matrix habitats, where, for example, some octocorals such as Pterogorgia anceps and $P$. guadalupensis can be abundant (Voss and Voss, 1955; Voss et al., 1969; Chiappone and Sullivan, 1994). Deeper-water $(>20 \mathrm{~m})$ habitats are also excluded for most years, which means that taxa in the "red" collector group are usually not encountered (e.g., Iciliogorgia schrammi and Swiftia exserta). In addition, the Florida Keys surveys are limited to just a small portion of the Florida coastline and thus do not include certain taxa (e.g., Leptogorgia) that are distributed 


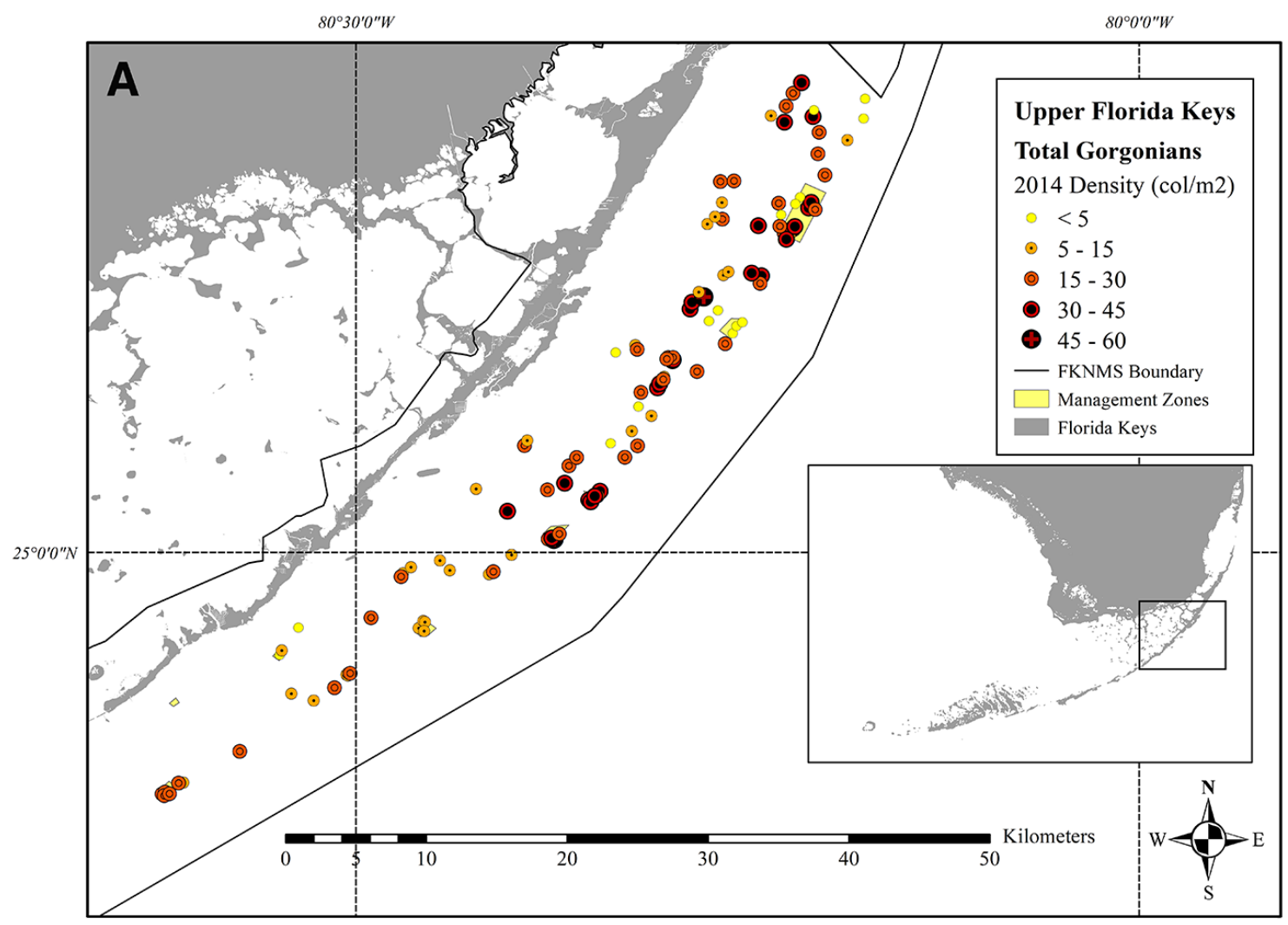

Figure 11.-Density (no. colonies $/ \mathrm{m}^{2}$ ) distribution maps A) for all encountered branching octocoral species combined and B-P) alphabetically by species in the upper Florida Keys from Carysfort Reef to Alligator Light, based upon surveys of replicate $8 \mathrm{~m} \mathrm{x} 1 \mathrm{~m}$ belt transects sampled per site at 102 hardbottom and reef sites during June-October 2014. Figure 11 continues on next eight pages.

further north in warm-temperate environments on both the Atlantic and Gulf of Mexico coasts.

An example of the fishery independent octocoral data are presented below for the upper Florida Keys from Carysfort Reef to inshore of northern Key Largo (Carysfort Reef), southwestwards to Alligator Light to inshore of Upper Matecumbe Key. This represents a small proportion of the Florida Keys reef tract, much less the southeastern Florida coast, but illustrates some of the basic patterns in octocoral distribution, density, and population sizes that help to place the octocoral fishery and historical and current collection levels into perspective. These data include the longest time series available and the most current data available (2014) for oc- tocorals the authors are aware of for the area.

Figure 11 illustrates the density distribution patterns of octocorals in the upper Florida Keys (northern Key Largo to Upper Matecumbe), based upon surveys from June-October 2014 (Table 9). The density distribution maps indicate that for all octocoral species combined, including those that are targeted in the octocoral fishery, most species are broadly distributed across the south Florida shelf. A few species, such as Antillogorgia kallos, Pterogorgia anceps and P. guadalupensis, appear to be relatively rare, but this may be due to the exclusion of nearshore hard-bottom and seagrass-hardbottom matric habitats in the survey design and/or the extremely patchy nature of some octocorals. Improv- ing population estimates for species that are patchy or rare requires adding more sites (possibly hundreds) to the sample design, increasing the costs and amount of in-water effort for the overall survey.

Figure 12 and Table 9 show density estimates combined for all habitats surveyed in the upper Florida Keys area for the following sample periods: 1999-2002 (combined), 2005, 2009, and 2014. For the collector color groups, overall mean densities for individual taxa and for combinations of taxa in color categories either have shown non-significant temporal changes or have increased (Table 9). Colony density increases occurred in nearly all of the taxa under the purple color category, in addition to nontargeted taxa. The relative density of 

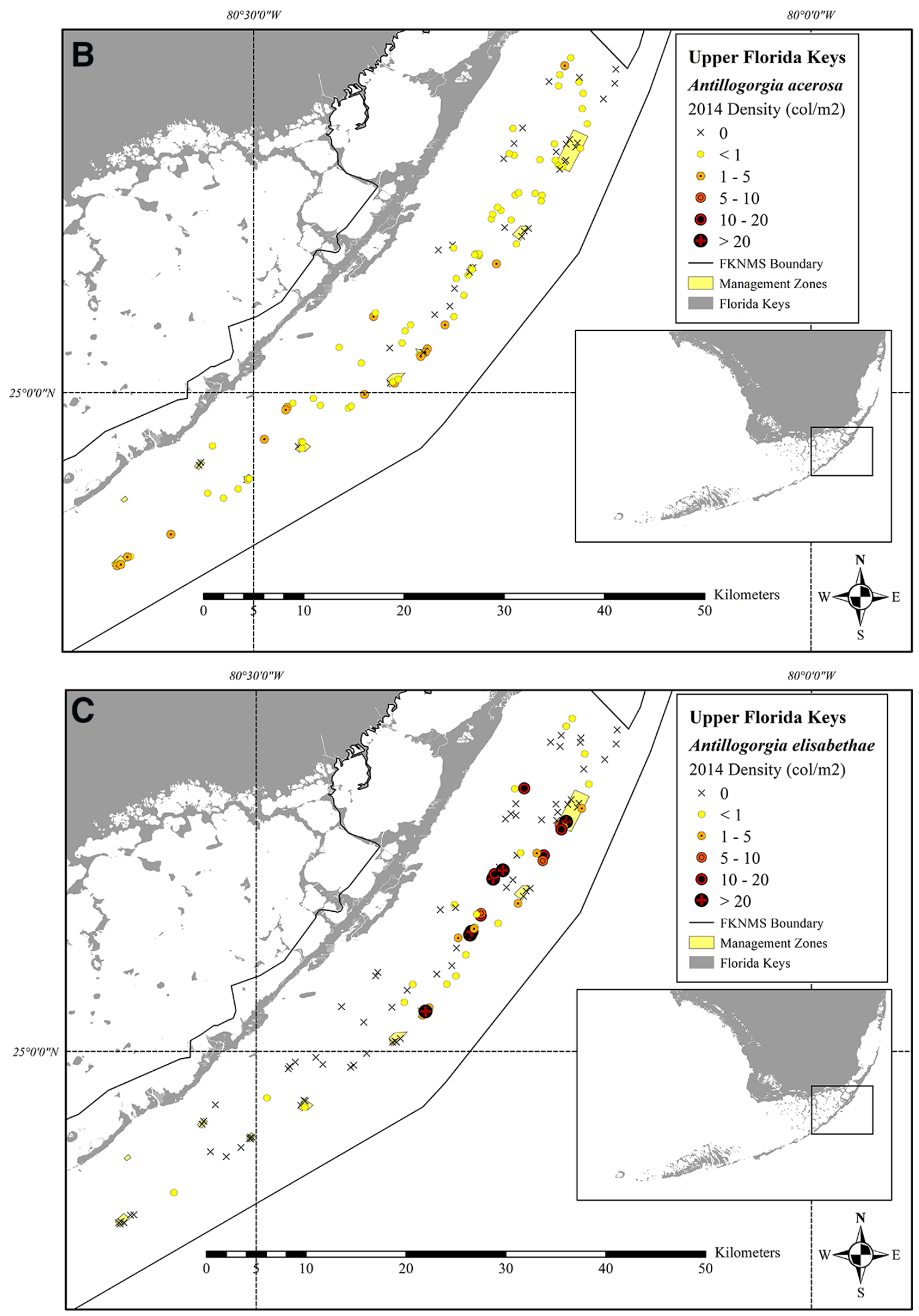

Figure 11._Continued. 

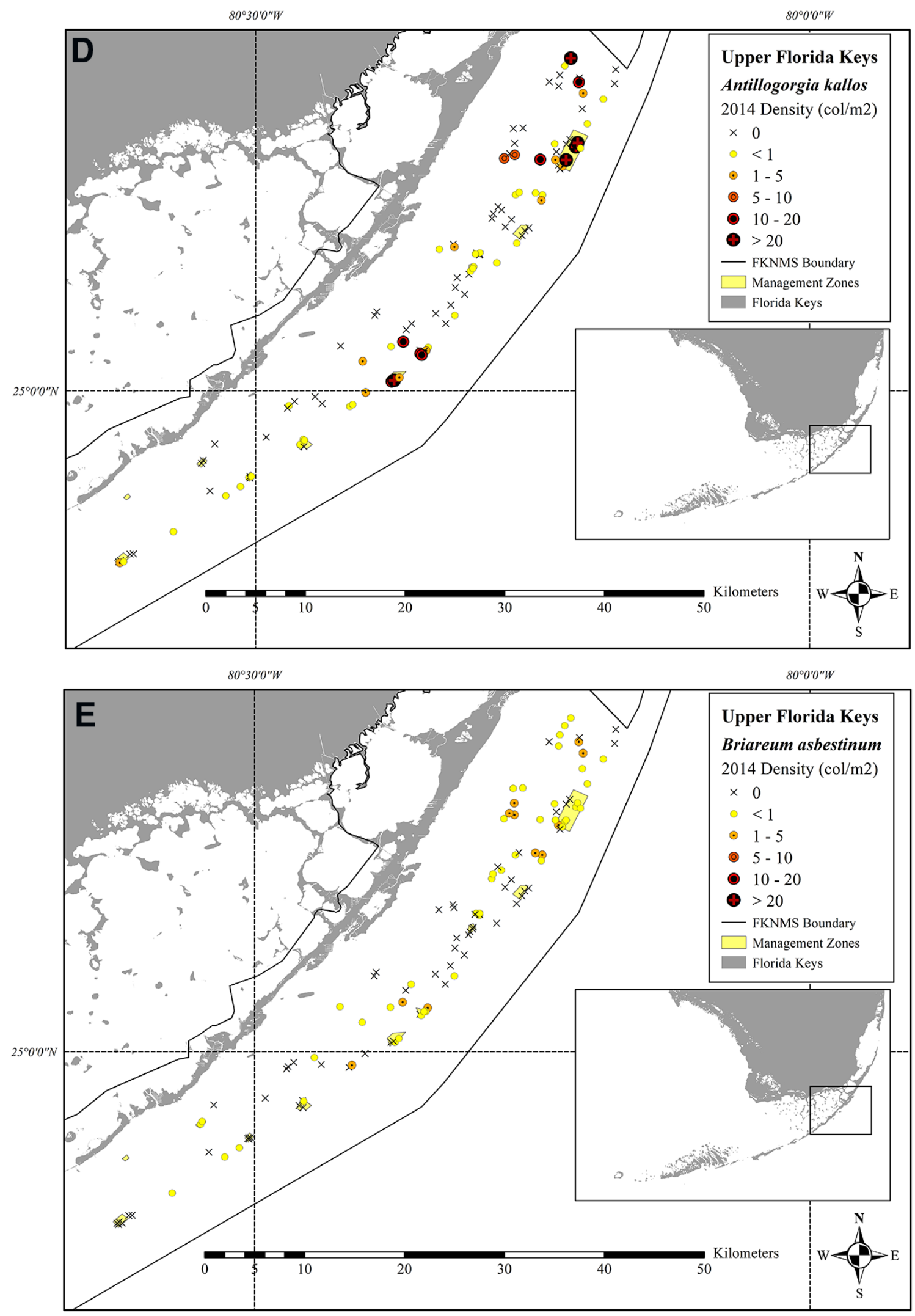

Figure 11.-Continued. 

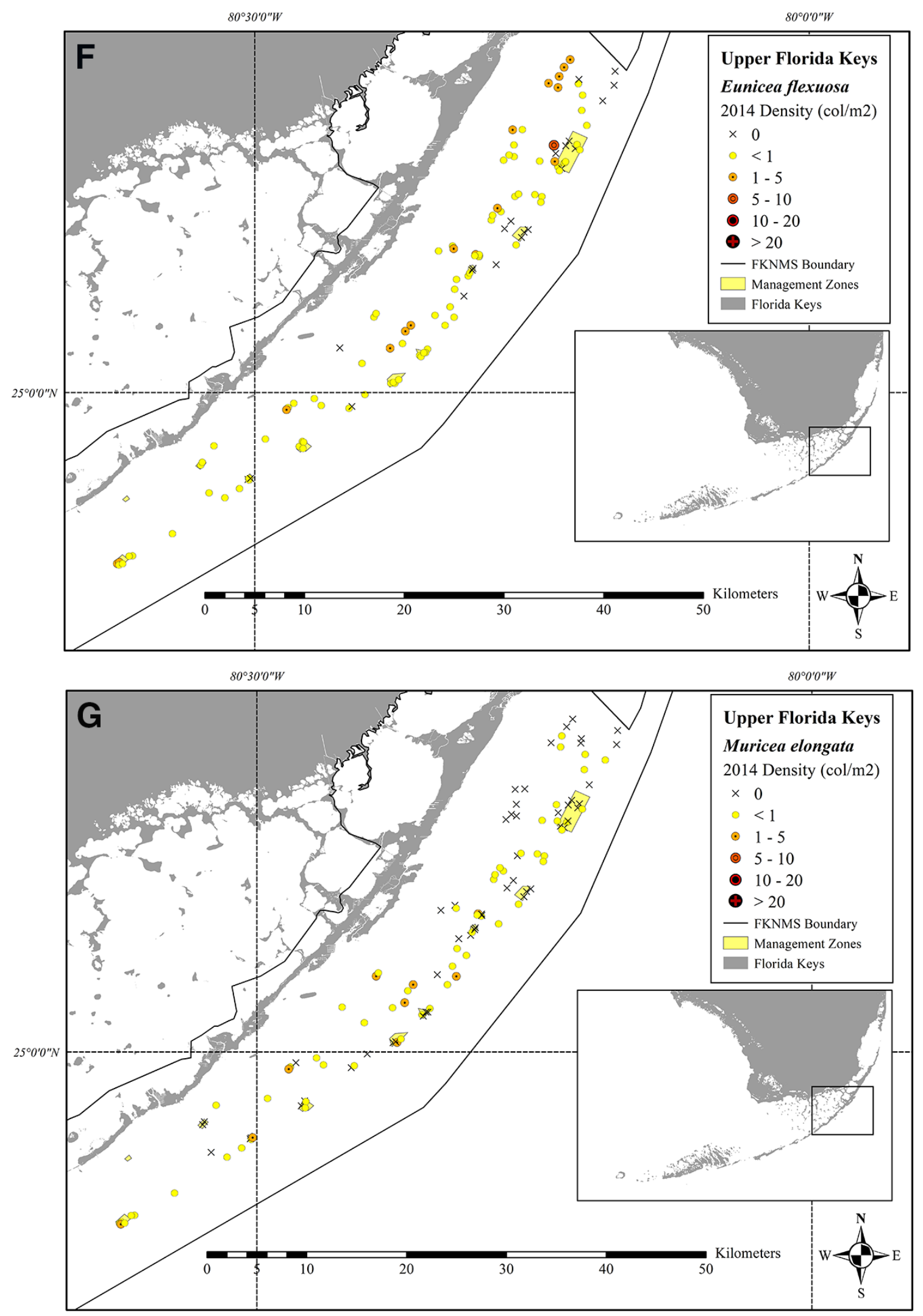

Figure 11.-Continued. 

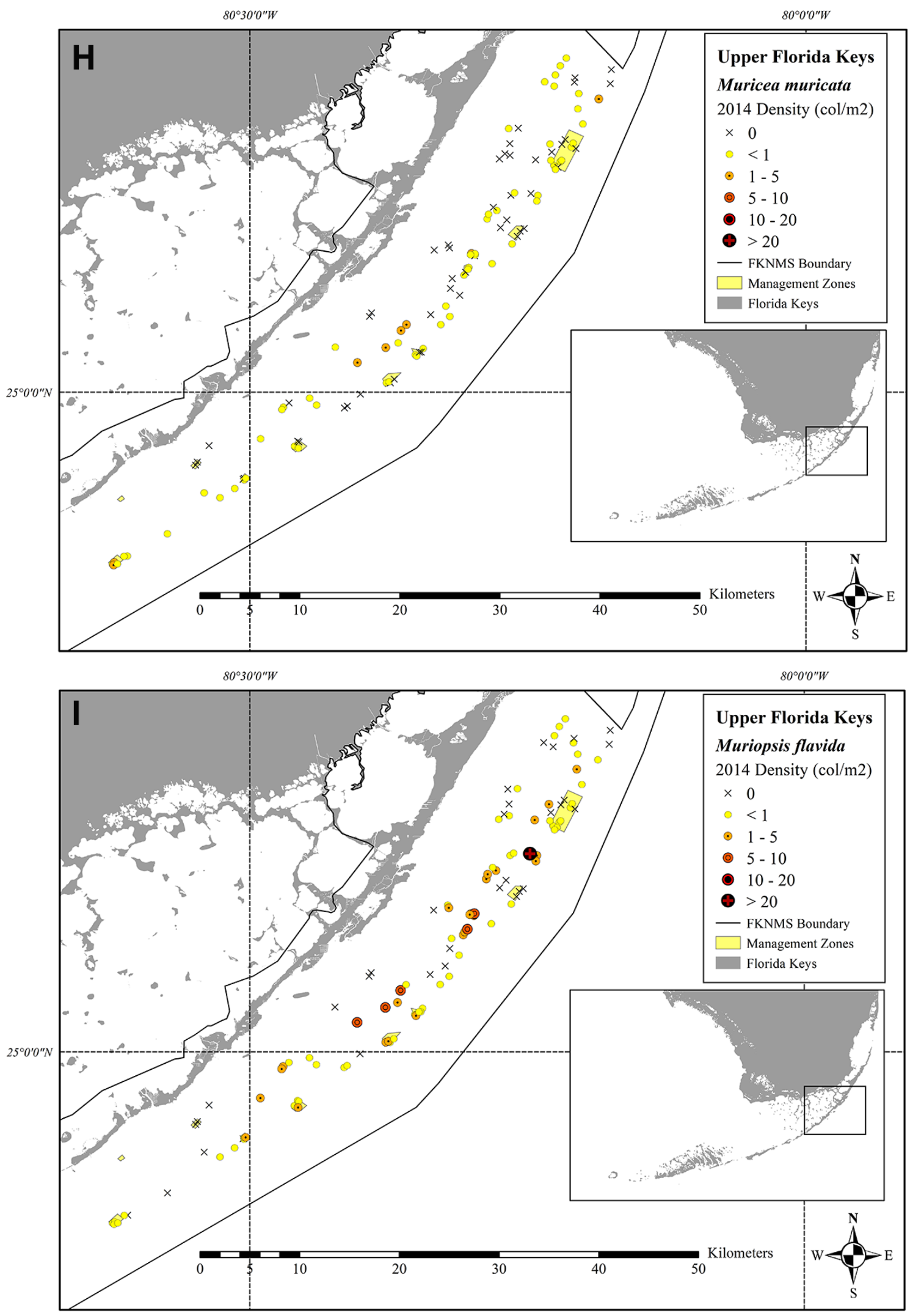

Figure 11.-Continued. 

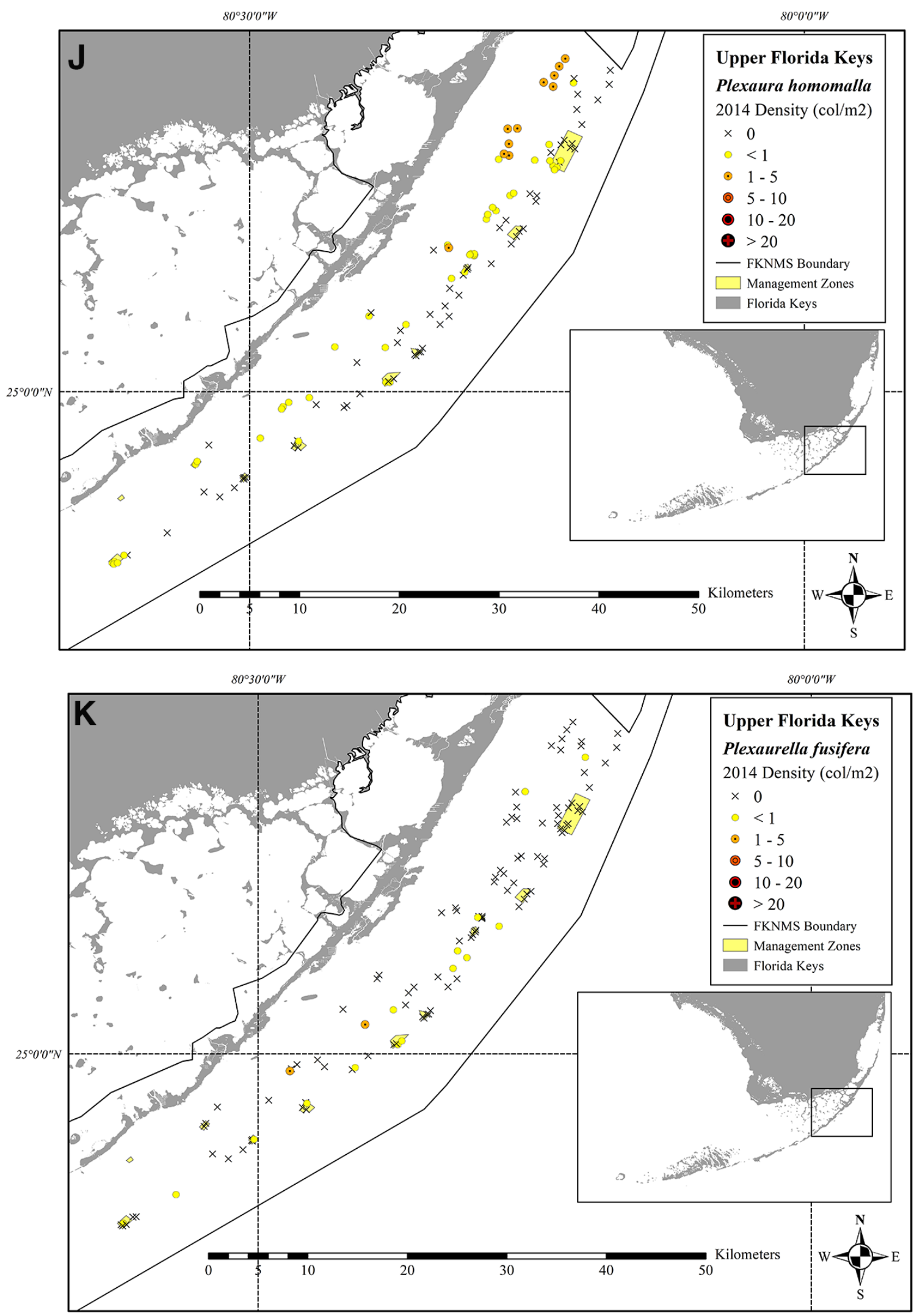

Figure 11.-Continued. 

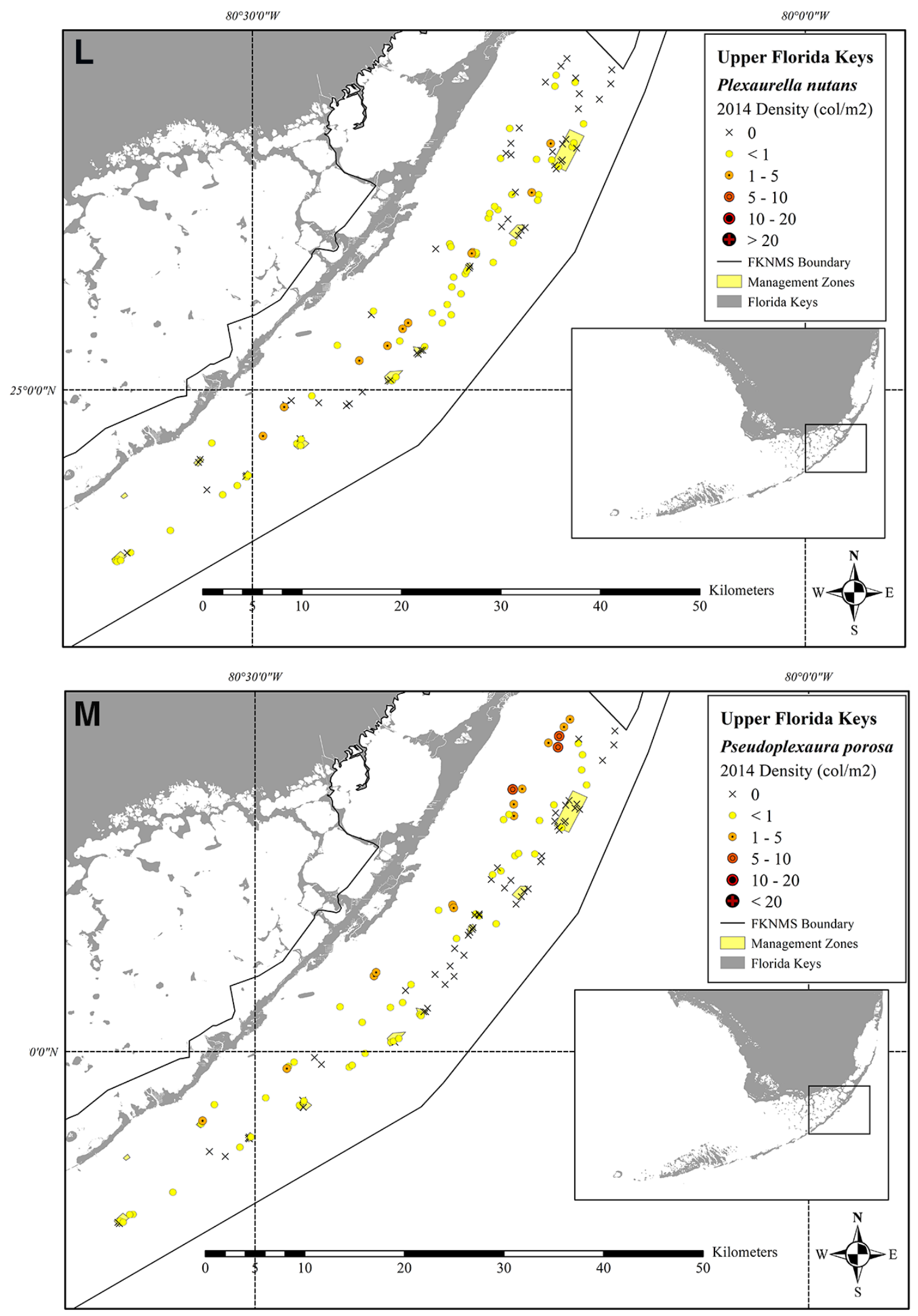

Figure 11.-Continued. 

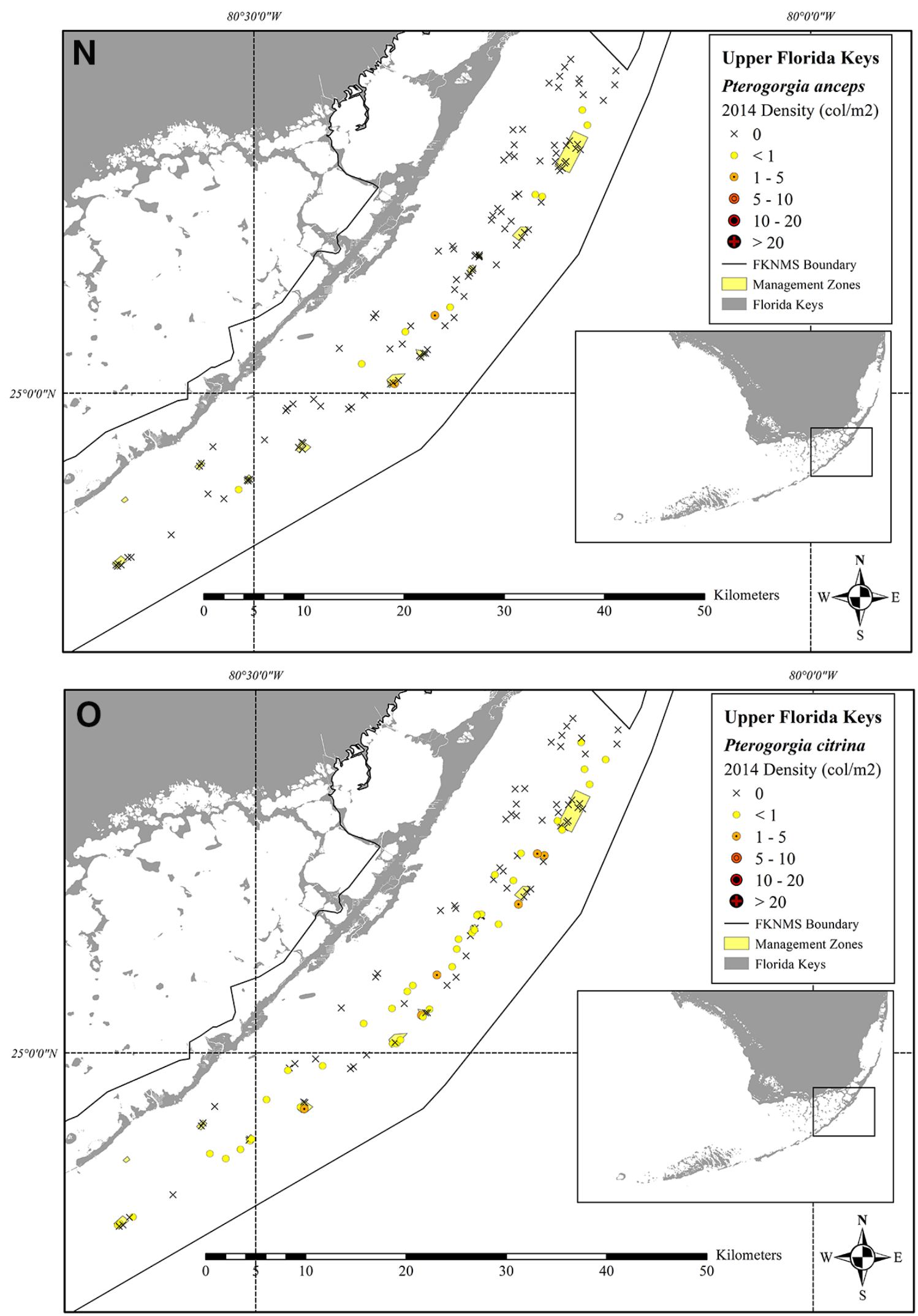

Figure 11.—Continued. 


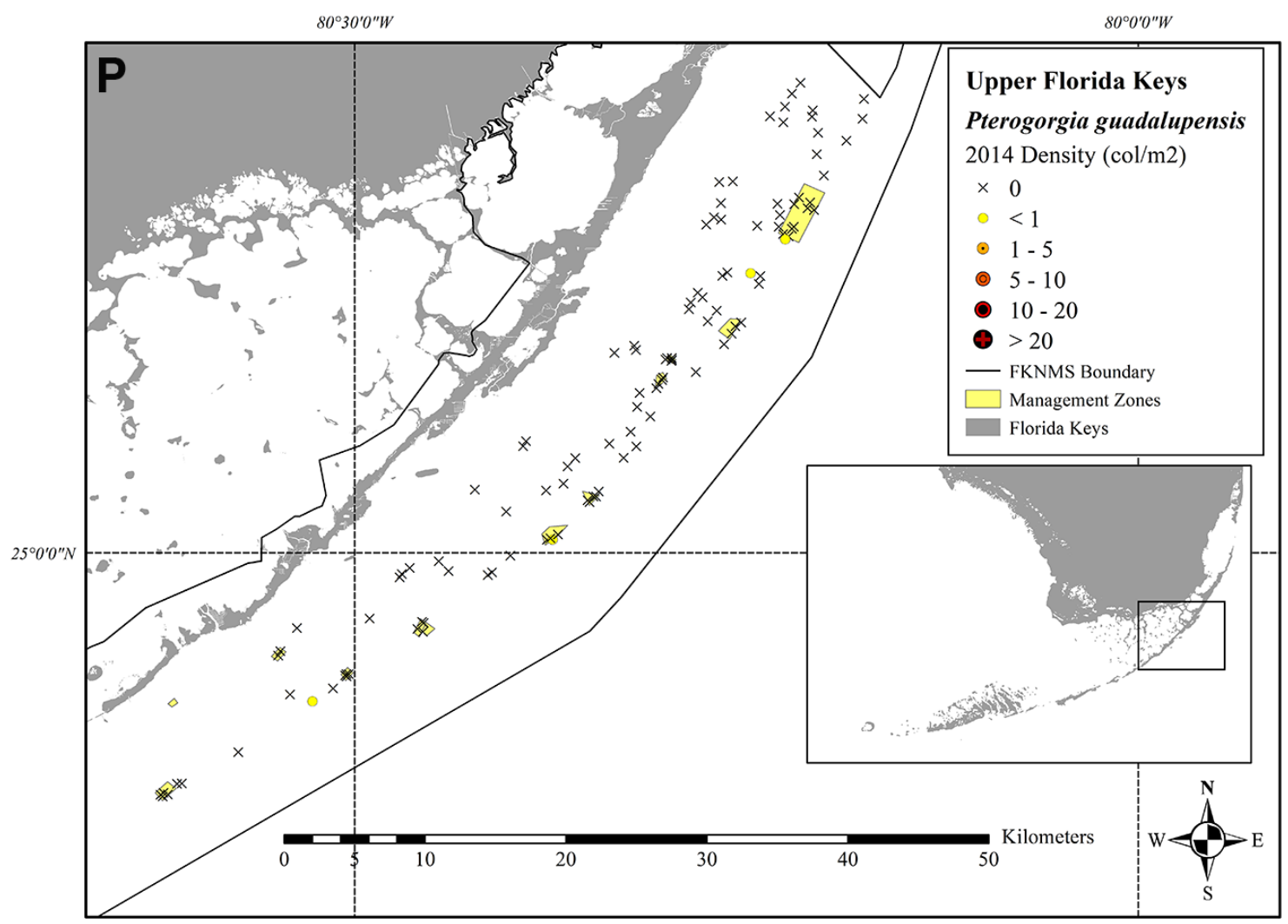

Figure 11.-Continued.

A

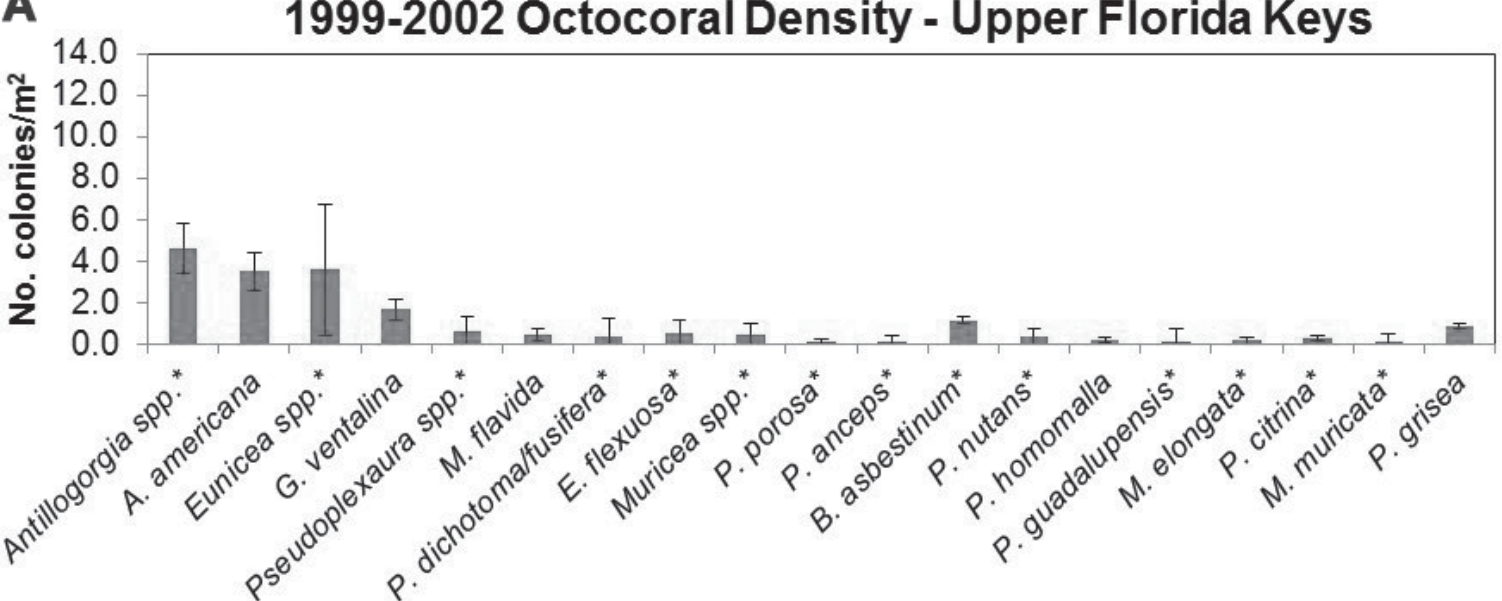

Figure 12.- Octocoral densities ( in the upper Florida Keys from Carysfort Reef, northern Key Largo to Alligator Light, Upper Matecumbe Key, based upon surveys during A) 1999-2002, B) 2005, C) 2009, and D) 2014. Species are ranked along the $\mathrm{x}$-axis based upon 2014 densities. Error bars represent 95\% confidence intervals. Octocoral species or genera targeted in the octocoral fishery are indicated with an asterisk $(*)$. 


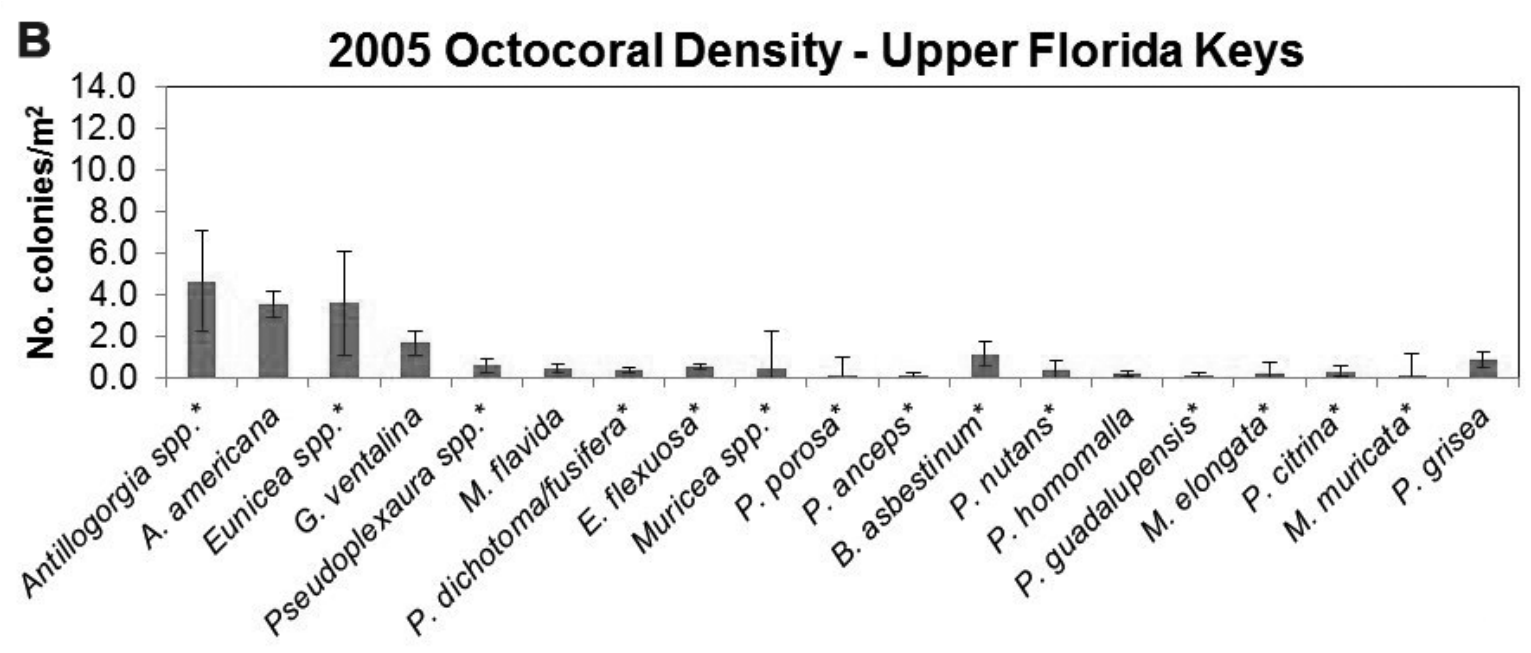

C 2009 Octocoral Density - Upper Florida Keys

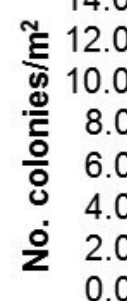

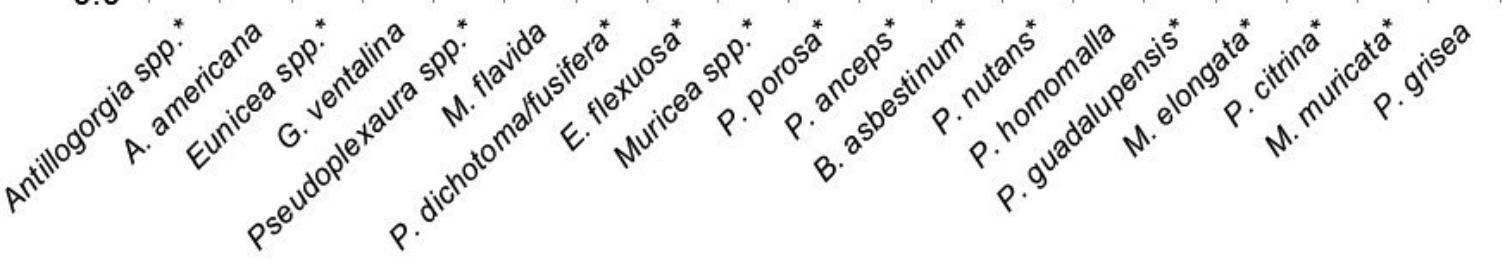

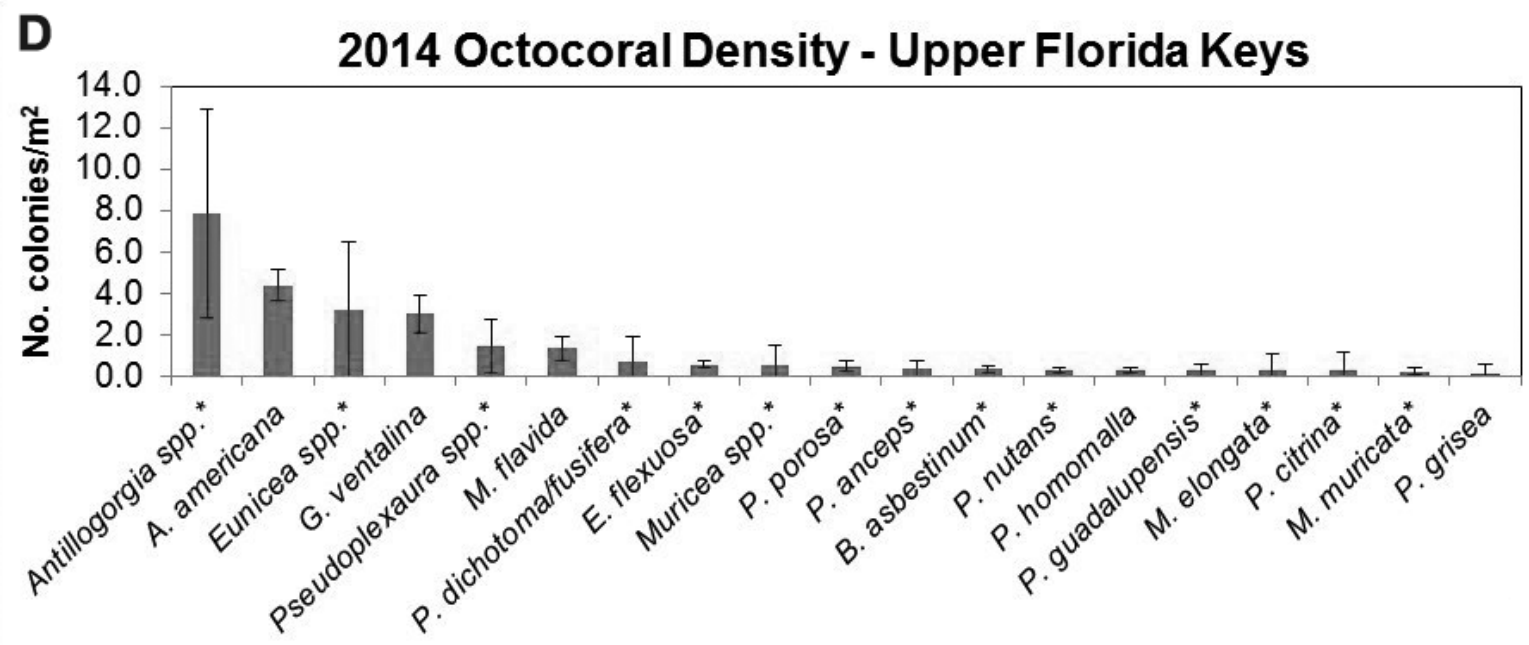

Figure 12.-Continued. 
Table 9.-Octocoral density estimates (mean no. colonies per $\mathrm{m}^{2} \pm 95 \% \mathrm{Cl}$ ) for sampled hard-bottom and coral reef habitats in the upper Florida Keys from Carysfort Reef, northern Key Largo to Alligator Light, Upper Matecumbe Key during 1999-2014. Asterisk (*) indicate the most highly valued species or genera targeted by the octocoral fishery. Octocorals are further divided by color group (i.e., purple, red, other). nd $=$ not encountered/no data. Note that octocorals in the red collector group (Diodogorgia, Ellisella, Iciliogorgia, Leptogorgia, Nicella, and Swiftia) were not encountered during the benthic surveys.

\begin{tabular}{|c|c|c|c|c|}
\hline Octocoral taxa/collector group & 1999-2002 & 2005 & 2009 & 2014 \\
\hline \multicolumn{5}{|l|}{ Other species group } \\
\hline Diodogorgia nodulifera* & nd & nd & nd & nd \\
\hline Muricea spp. .1 $^{1}$ & $1.24 \pm 0.53$ & $0.43 \pm 1.80$ & $0.29 \pm 1.43$ & $0.50 \pm 1.01$ \\
\hline M. elongata & $0.33 \pm 0.16$ & $0.16 \pm 0.56$ & $0.13 \pm 0.85$ & $0.26 \pm 0.85$ \\
\hline M. muricata & $0.92 \pm 0.38$ & $0.15 \pm 1.00$ & $0.16 \pm 0.57$ & $0.23 \pm 0.16$ \\
\hline M. pinnata & nd & nd & nd & nd \\
\hline Plexaura homomalla & $0.33 \pm 0.14$ & $0.19 \pm 0.13$ & $0.16 \pm 0.11$ & $0.29 \pm 0.12$ \\
\hline Plexaurella dichotoma/fusifera & $0.25 \pm 0.87$ & $0.36 \pm 0.16$ & $0.29 \pm 0.13$ & $0.68 \pm 1.24$ \\
\hline P. nutans* & $0.28 \pm 0.41$ & $0.37 \pm 0.45$ & $0.13 \pm 0.25$ & $0.30 \pm 0.13$ \\
\hline Pterogoria citrina* & $0.23 \pm 0.11$ & $0.30 \pm 0.26$ & $0.28 \pm 0.20$ & $0.25 \pm 0.86$ \\
\hline$\overline{\text { Total density (other) }}$ & $2.33 \pm 2.06$ & $1.65 \pm 2.81$ & $1.14 \pm 2.12$ & $2.02 \pm 3.36$ \\
\hline \multicolumn{5}{|l|}{ Purple species group } \\
\hline Antillogorgia spp. ${ }^{* 2}$ & $3.05 \pm 1.21$ & $4.64 \pm 2.42$ & $5.41 \pm 2.21$ & $7.86 \pm 5.01$ \\
\hline Briareum asbestinum* & $0.29 \pm 0.17$ & $1.14 \pm 0.58$ & $0.93 \pm 0.57$ & $0.33 \pm 0.13$ \\
\hline Eunicea spp. ${ }^{3}$ & $2.30 \pm 3.16$ & $3.59 \pm 2.49$ & $1.58 \pm 2.72$ & $3.22 \pm 3.29$ \\
\hline E. flexuosa* & $0.29 \pm 0.59$ & $0.53 \pm 0.16$ & $0.35 \pm 0.12$ & $0.54 \pm 0.16$ \\
\hline Muriceopsis flavida* & $0.39 \pm 0.26$ & $0.45 \pm 0.23$ & $0.53 \pm 0.21$ & $1.33 \pm 0.60$ \\
\hline Pseudoplexaura spp. ${ }^{4}$ & $0.93 \pm 0.74$ & $0.59 \pm 0.35$ & $0.98 \pm 0.89$ & $1.44 \pm 1.30$ \\
\hline P. porosa & $0.13 \pm 0.14$ & $0.12 \pm 0.90$ & $0.33 \pm 0.25$ & $0.48 \pm 0.23$ \\
\hline Pterogorgia anceps* & $0.28 \pm 0.32$ & $0.12 \pm 0.11$ & $0.75 \pm 0.58$ & $0.36 \pm 0.42$ \\
\hline P. guadalupensis & $0.66 \pm 0.60$ & $0.13 \pm 0.11$ & $0.13 \pm 0.25$ & $0.27 \pm 0.32$ \\
\hline Total density (purple) & $8.32 \pm 7.19$ & $\overline{11.32 \pm 7.36}$ & $\overline{10.97 \pm 7.79}$ & $\overline{15.82 \pm 11.47}$ \\
\hline \multicolumn{5}{|l|}{ Not targeted } \\
\hline A. americana & $3.97 \pm 0.92$ & $3.52 \pm 0.61$ & $4.42 \pm 0.88$ & $4.40 \pm 0.73$ \\
\hline Gorgonia ventalina & $1.78 \pm 0.49$ & $1.67 \pm 0.57$ & $2.87 \pm 0.80$ & $2.99 \pm 0.89$ \\
\hline P. kuna 4 & nd & $0.32 \pm 0.55$ & $0.14 \pm 0.11$ & $0.65 \pm 0.60$ \\
\hline P. grisea & $0.32 \pm 0.13$ & $0.85 \pm 0.40$ & $0.68 \pm 0.46$ & $0.12 \pm 0.47$ \\
\hline Total density (not targeted) & $6.07 \pm 1.53$ & $6.37 \pm 2.13$ & $8.10 \pm 2.25$ & $8.16 \pm 2.69$ \\
\hline Total octocoral density (all groups) & $16.72 \pm 10.79$ & $19.33 \pm 12.29$ & $20.22 \pm 12.17$ & $26.00 \pm 17.52$ \\
\hline
\end{tabular}

${ }^{1}$ Includes the taxa $M$. elongata, $M$. laxa, and $M$. muricata

${ }^{2}$ Includes the taxa A. acerosa, A. bipinnata, A. elisabethae, A. kallos, and A. rigida. Although A. acerosa can be yellowgolden in color and is included in both the purple and other categories, $>99 \%$ of colonies encountered are purple and are thus included in the purple category.

Includes the taxa E. calyculata, E. fusca, E. knighti, E. mammosa, E. palmeri, E. succinea and E. tourneforti ${ }^{4}$ Includes the taxa $P$. flagellosa, $P$. wagenaari, and unidentifiable Pseudoplexaura colonies

${ }^{5}$ Plexaura kuna was not distinguished from Eunicea flexuosa, then known as Plexaura flexuosa, during 1999-2002.

octocoral species, comparing the top ten densest species in the upper Florida Keys, remained mostly unchanged (Fig. 12).

\section{Florida Keys Population Abundance Estimates}

Estimates of octocoral abundance for the upper Florida Keys are illustrated in Figure 13 and Table 10. Population abundance estimates are based upon colony densities and habitat area and demonstrate the large population sizes (tens to hundreds of millions of colonies) for most gorgonian taxa. Total colony abundances in the upper Florida Keys either suggest non-significant changes over time or increases (Table 10). The relative abundance of octocoral species, comparing the top ten densest species in the upper Florida Keys, is mostly unchanged based upon surveys in 1999-2002, 2005, 2009, and 2014 (Fig. 13). Table 11 lists octocoral abundance estimates for the Florida Keys, excluding the Marquesas and Dry Tortugas, from 1999-2009, which are referenced below to help evaluate the impact of octocoral fishery landings from FWC trip ticket data relative to estimated population sizes.

\section{Fishery Information Needs and Management Recommendations}

\section{Assessment of Identification Aides}

General knowledge about octocorals targeted in the marine life trade is probably sufficient to address many of the fundamental questions related to species identifications, life history, and population abundance. Bayer (1961) published one of the first octocoral identification guides for the western Atlantic that included an illustrated key to over 100 species within four orders: Telestacea, Alcyonacea, Gorgonacea, and Pennatulacea. In 1977, Cairns (1977) published a follow-up identification guide of common octocorals that included photographs of dried colonies from Florida, the Caribbean, and Gulf of Mexico. Sánchez and Wirshing (2005) improved upon these and other earlier works, with their field guide to zooxanthellate octocorals in the western Atlantic. High-resolution in-situ photographs and flow charts based on basic morphological characters were meant to be used as a quick field reference for identification. In 2011, Dr. C. Messing of Nova Southeastern University (NSU) spearheaded a workshop to develop an online interactive guide to South Florida octocorals funded as part of this overall octocoral fishery investigation. With assistance from leading octocoral experts, samples that had been photographed in-situ, and then preserved, were positively identified using microscopic examination of sclerites. Large dried colonies from the NSU invertebrate collection were also photographed. The major outcome of the workshop was a web-based octocoral guide (www. cnso.nova.edu/ncri/sofla_octocoral_ guide/index.html/). Users can search through a list of octocoral species or click through character menus related to growth form, color, or aperture shape to narrow species searches. Once a species is selected, a page is linked that includes information on its habitat and ecology, along with photographs. Currently, the South Florida octocoral identification guide includes 47 species. The guide, plus other taxonomic records, were used to help inform the production of a fisheryspecific identification guide that was developed as part of this octocoral fishery project.

To supplement the online interactive South Florida octocoral guide described above, a waterproof field guide has been suggested as a potentially useful tool for octocoral collec- 

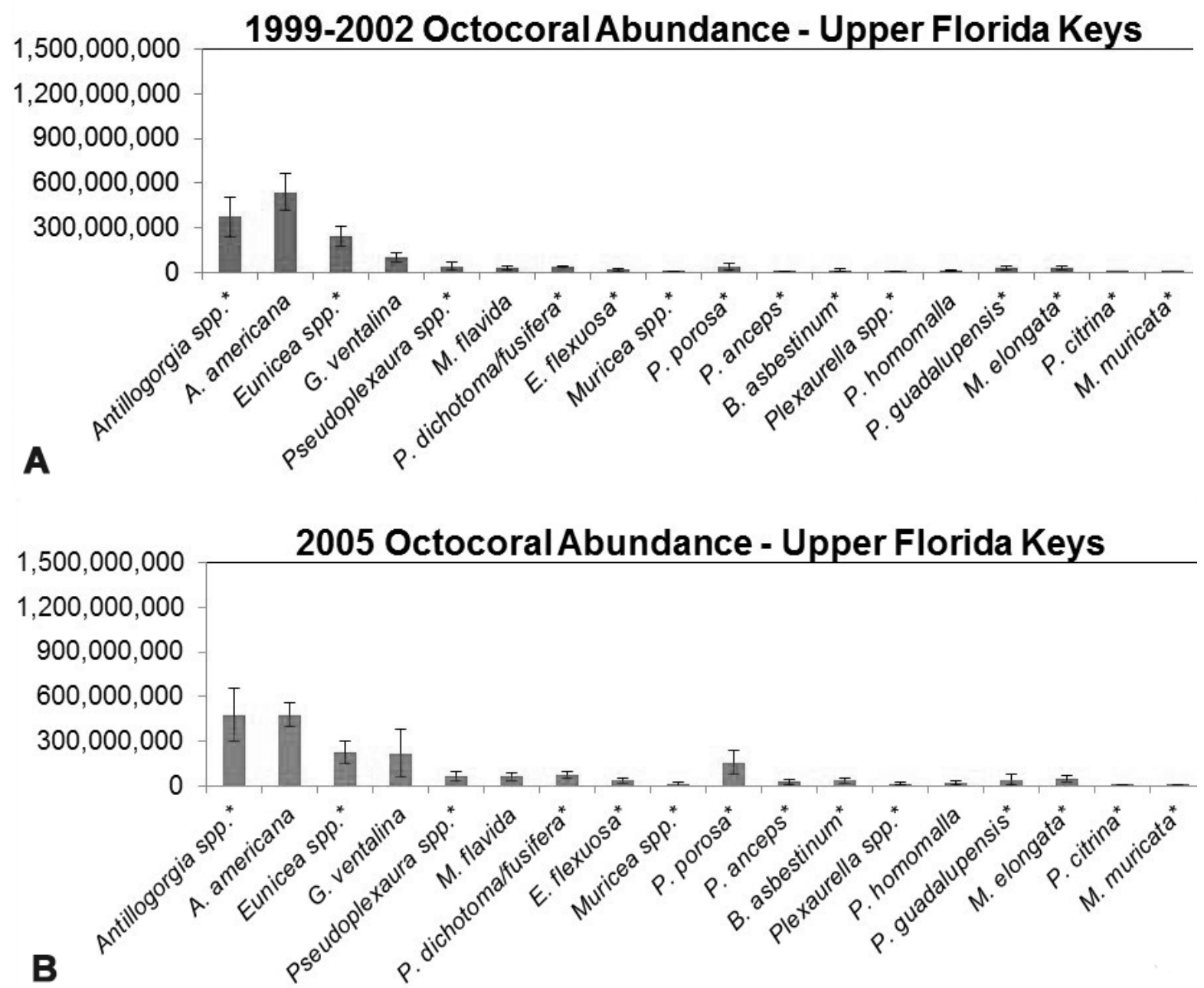

Figure 13.-Octocoral abundance (total colonies) in the upper Florida Keys from Carysfort Reef, northern Key Largo to Alligator Light, Upper Matecumbe Key, based upon surveys during A) 1999-2002, B) 2005, C) 2009, and D) 2014. Species are ranked along the x-axis from high-to-low based upon 2014 abundances. Error bars represent $95 \%$ confidence intervals. Octocoral species or genera targeted in the octocoral fishery are indicated with an asterisk $(*)$.

Figure 13 continues on next page.

tors, with a broader intended audience to include law enforcement, hobbyists, and the public. A guide is currently being developed that will be organized by the color headings currently used to report collection activities in the FWC Trip Ticket reports (i.e., other, purple, and red categories). Under each heading, color photographs taken in situ of the octocoral species commonly collected in the fishery will list both the scientific name and the official common name. A major discrepancy within the marine life fishery is the misuse of common names such that a single species may be known by several common names (Bayer, 1961; Voss et al., 1969; Cairns, 1977; Cairns et al., 2002). This complicates and confuses the tracking and marketing of species sold within the fishery. Furthermore, species misidentification is an ongoing problem for both the fishery and scientific communities. A goal of the field guide is to provide a tool that can be used by all participants within the marine life fishery (e.g., collector, wholesaler, hobbyist, and law enforcement) to help create consistency with the identification and naming of octo- corals. To assist in identification, basic habitats where octocoral species occur, collection depths, and distinguishing diagnostic characteristics will be noted for each species. Figure 14 presents a draft page from the field guide. If ongoing interest exists, workshops could be held to assist collectors in the use of these guides.

\section{Life History Traits}

There is nothing unusual or notable about octocoral life histories that suggest that the current level of collection, based upon collector interviews, 

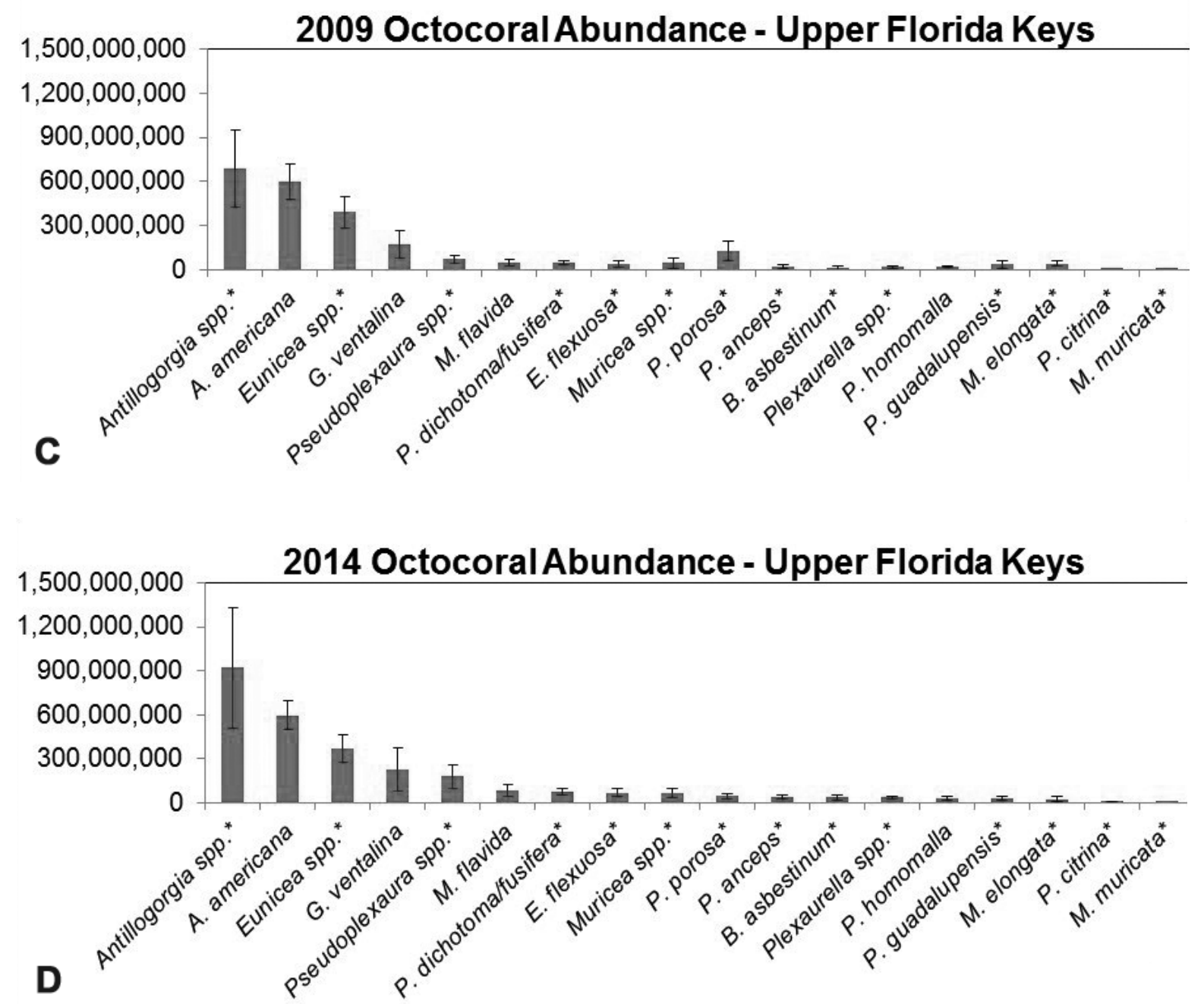

Figure 13.-Continued.

FWC trip ticket data, and available fishery independent assessments, is a threat to the sustainability of octocoral populations. The majority of wider Caribbean octocorals reproduce sexually, with male and female colonies that are distinct. There is no indication that octocoral collectors selectively target colonies based upon gender. Many species also reproduce asexually through fragmentation and vegetative propagation, supporting high population growth rates (Lasker, 1988; Kahng et al., 2011). Many octocoral colonies spawn over several days over consecutive months in a year (Fitzsimmons-Sosa et al., 2004; Gutierrez-Rodriguez and Lasker, 2004). Of the octocoral species collected for the aquarium trade (23 species and 15 genera), reproductive mode and timing of reproduction is known for 12 species. The majority of these (10 of 12 species) are broadcast spawners that release gametes during the summer months. Antillogorgia elisabethae and Muriceopsis flavida, on the other hand, release gametes during the winter months (Kahng et al., 2011). Brooding species, where males release gametes that fertilize eggs retained by females, include A. elisabethae, Briareum asbestinum, Muriceopsis flavida, and Pterogorgia anceps (Ritson-Williams, 2010; Kahng et al., 2011). The planula of brooders, which form from the fertilized egg and have cilia or hair-like projections that aid in move- ment, settle immediately after detaching from the parental colony (Brazeau and Lasker, 1990). This is significant because brooding colonies can contribute directly to the population dynamics of the immediate reef area. If substantial quantities of adult colonies of any of these brooding species were removed from a single area, similar to forest clear-cutting, then one would expect a significant decrease in reproductive output (Goffredo and Lasker, 2008). The collectors interviewed for this report stated that clear-cutting for octocorals is not practiced.

Octocorals generally grow faster than most stony corals, with linear branch extensions of $4 \mathrm{~cm} / \mathrm{yr}$ in thinly branched species of Antillogorgia, 


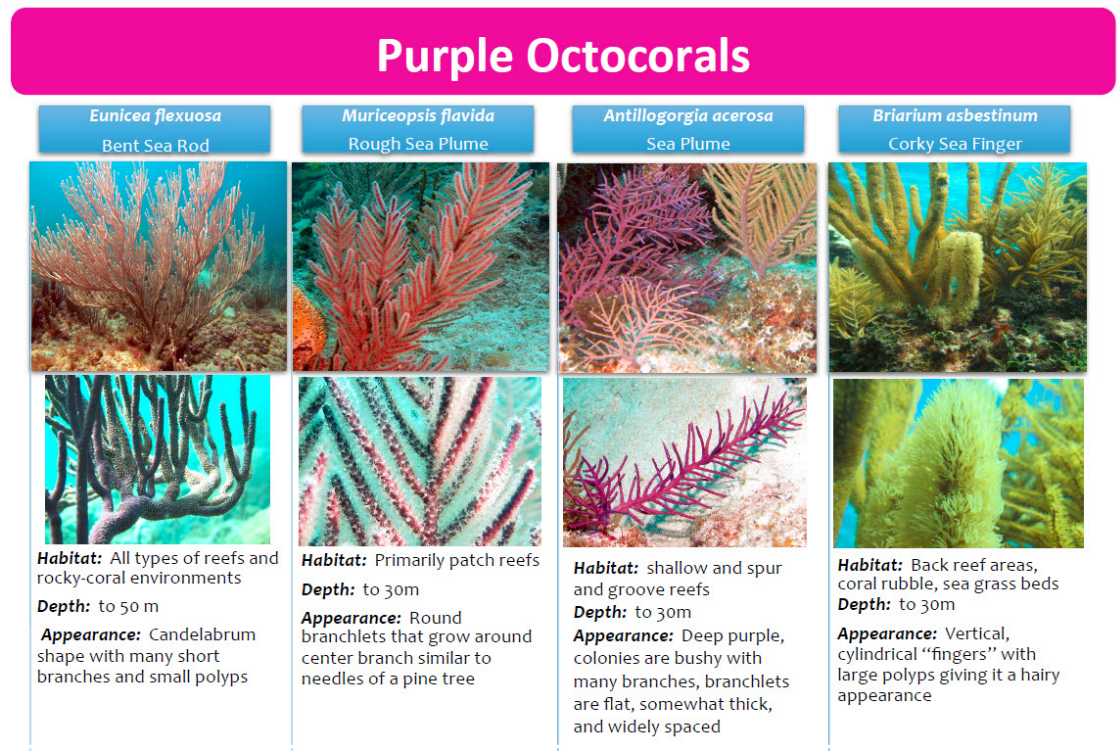

Figure 14. - Draft page for the Octocoral Field Identification Guide.

Muricea, and Muriceopsis. However, thicker branched species such as Plexaurella barely grow $1 \mathrm{~cm} / \mathrm{yr}$ (Yoshioka and Yoshioka, 1991). Faster-growing species tend to be found at higher densities (Yoshioka, 1997). Octocorals typically reach sexual maturity when they are over $20 \mathrm{~cm}$ in height. An exception is Pterogorgia citrina, a small bushy octocoral that rarely grows above $30 \mathrm{~cm}$ in height that may reach sexual maturity sooner; however, little is known about this species. To provide adequately sized octocorals to home aquarists, collectors usually take colonies $<20 \mathrm{~cm}$ in height. In doing so, they leave larger colonies behind that are the major contributors of gametes to the population (Beiring and Lasker, 2000). The octocoral collectors interviewed indicated that they rotate collection sites and are selective in which colonies they collect. As aesthetics is a major factor in marketability of octocoral colonies, many 'imperfect' colonies are passed over by collectors.

In the Bahamas, colonies of Antillogorgia elisabethae are clipped and collected for the cosmetics industry. The bioactive compound pseudopterosin found in this species is an antiinflammatory agent that is added to cosmetic products (Look et al., 1986).
Colonies of A. elisabethae are collected by cropping colonies that are 5-15 $\mathrm{cm}$ in height and collectors rotate sites on a 2-3 yr basis to allow recovery before re-collecting. Castanaro and Lasker (2003) measured accelerated growth rates among collected colonies, particularly those that retained at least 12 branches in size. However, because collected colonies are smaller, fewer zygotes are produced, reducing recruitment at collection sites. As a result, collectors have switched to collecting at 5-yr intervals to give colonies greater time to reproduce before the next collection (Goffredo and Lasker, 2008). Octocoral collectors in Florida who clip 20-cm fragments from adult colonies for Eco-Gorgs ${ }^{\circledR}$ leave behind over $80 \%$ of the colony. The impact on reproduction is probably minimal to individual colonies and insignificant to the larger population because only a small fraction of the larger population is clipped for fragments, but this requires additional study to confirm.

\section{Information Gaps in Life History}

Though some species of octocorals are relatively well-studied (e.g., Antillogorgia spp., Eunicea flexuosa, Gor- gonia ventalina, Plexaura kuna, $P$. homomalla), gaps in life history data exist for several targeted genera and species. Besides distribution data and one study on reproduction (RitsonWilliams, 2010), for example, the only well-studied aspect of the genus Pterogorgia are the secondary metabolites found within its tissues (Schmitz and Lorance, 1971; Lorance, 1977; Pawlik and Fenical, 1992; Rodriguez and Ramirez, 1994; Jensen et al., 1996). A brief observation in October 2009 of surface brooding in colonies of $P$. anceps in Belize was noted by RitsonWilliams (2010). This paucity of life history data is somewhat unusual for a common, easily identifiable, shallowwater genus. As noted above, surveys focusing on size and mode of reproduction would be relevant in Pterogorgia to determine how size and morphology are related to reproductive output. However, this interest might be largely academic, because there is no evidence to suggest that population numbers are being adversely impacted at current collection levels in the U.S. South Atlantic. There is also a paucity of life history information on octocorals of the genus Muricea; only information on the breeding period of $M$. atlantica (gametes are present June-September) is available (Fitzsimmons and Hallock Mueller, 1996). Even though it is a commonly requested octocoral for the aquarium trade, additional studies are not considered a priority because existing population numbers appear to be large enough in relation to current collection levels.

Studies of octocorals at deeper (30+ m) depths (e.g., Diodogorgia nodulifera and Swiftia exserta) have primarily described their presence or absence at various locations throughout the wider Caribbean (Bayer, 1961; Veronique, 1987; Humann, 1993). Density data for these two deepwater species are not available from the literature. Anecdotally, information from collectors suggests that these species are found in high densities in Palm Beach County, with colonies spaced a few centimeters apart, and at relatively high colony densities in Miami-Dade County, with 
Table 10. - Octocoral abundance estimates (total colonies $\pm 95 \% \mathrm{Cl}$ ) in sampled hard-bottom and coral reef habitats in the upper Florida Keys from Carysfort Reef, northern Key Largo to Alligator Light, Upper Matecumbe Key during 1999-2014. Asterisks $\left(^{*}\right)$ indicate the most highly valued octocoral species or genera targeted by the fishery. Octocorals are further divided by color group (i.e. purple, red, and other). nd = no data. Note that octocorals in the red collector group (e.g. Diodogorgia, Ellisella, Iciliogorgia, Leptogorgia, Nicella, and Swiftia) were not encountered during the upper Florida Keys benthic surveys.

\begin{tabular}{|c|c|c|c|c|}
\hline Octocoral taxa/collector group & 1999-2002 & 2005 & 2009 & 2014 \\
\hline \multicolumn{5}{|l|}{ Other species group } \\
\hline Diodogorgia nodulifera* & & nd & nd & nd \\
\hline Muricea spp. ${ }^{\star 1}$ & $\begin{array}{c}16,797,660 \pm \\
7,211,207\end{array}$ & $\begin{array}{c}34,960,192 \pm \\
20,322,052\end{array}$ & $\begin{array}{c}39,246,900 \pm \\
19,373,360\end{array}$ & $\begin{array}{c}67,777,312 \pm \\
25,963,333\end{array}$ \\
\hline M. elongata & $\begin{array}{c}4,359,698 \pm \\
2,111,128\end{array}$ & $\begin{array}{c}14,376,154 \pm \\
7,629,469\end{array}$ & $\begin{array}{c}17,839,500 \pm \\
11,605,665\end{array}$ & $\begin{array}{c}35,989,570 \pm \\
11,493,995\end{array}$ \\
\hline M. muricata & $\begin{array}{c}12,437,962 \pm \\
5,100,079\end{array}$ & $\begin{array}{c}20,420,673 \pm \\
12,368,587\end{array}$ & $\begin{array}{c}21,407,400 \pm \\
7,767,695\end{array}$ & $\begin{array}{c}31,787,742 \pm \\
14,469,338\end{array}$ \\
\hline M. pinnata & nd & nd & nd & nd \\
\hline Plexaura homomalla & $\begin{array}{c}4,487,925 \pm \\
1,945,163\end{array}$ & $\begin{array}{c}25,811,731 \pm \\
18,330,061\end{array}$ & $\begin{array}{c}21,917,100 \pm \\
15,532,634\end{array}$ & $\begin{array}{c}38,912,581 \pm \\
16,817,943\end{array}$ \\
\hline Plexaurella spp.* & $\begin{array}{c}28,209,811 \pm \\
12,326,630\end{array}$ & $\begin{array}{c}49,826,442 \pm \\
22,861,624\end{array}$ & $\begin{array}{c}39,586,700 \pm \\
18,595,991\end{array}$ & $\begin{array}{c}64,397,581 \pm \\
33,864,573\end{array}$ \\
\hline Pterogorgia citrina* & $\begin{array}{c}30,902,566 \pm \\
15,140,642\end{array}$ & $\begin{array}{c}39,534,423 \pm \\
35,182,956\end{array}$ & $\begin{array}{c}37,887,700 \pm \\
26,772,620\end{array}$ & $\begin{array}{c}27,859,946 \pm \\
11,742,691\end{array}$ \\
\hline Total abundance (other) & $\begin{array}{c}80,397,962 \pm \\
36,623,642\end{array}$ & $\begin{array}{c}150,132,788 \pm \\
96,696,692\end{array}$ & $\begin{array}{c}138,638,400 \pm \\
80,274,605\end{array}$ & $\begin{array}{c}198,947,419 \pm \\
88,388,542\end{array}$ \\
\hline \multicolumn{5}{|l|}{ Purple species group } \\
\hline Antillogorgia spp.*2 & $\begin{array}{c}374,677,585 \pm \\
132,298,971\end{array}$ & $\begin{array}{c}478,170,481 \pm \\
176,419,729\end{array}$ & $\begin{array}{c}688,264,900 \pm \\
258,903,714\end{array}$ & $\begin{array}{c}923,580,054 \pm \\
412,160,297\end{array}$ \\
\hline Briareum asbestinum* & $\begin{array}{c}39,237,283 \pm \\
23,377,355\end{array}$ & $\begin{array}{c}155,197,115 \pm \\
79,368,560\end{array}$ & $\begin{array}{c}125,726,000 \pm \\
68,905,724\end{array}$ & $\begin{array}{c}44,758,602 \pm \\
18,241,600\end{array}$ \\
\hline Eunicea spp. ${ }^{3}$ & $\begin{array}{c}99,631,925 \pm \\
33,934,826\end{array}$ & $\begin{array}{c}219,399,712 \pm \\
157,299,336\end{array}$ & $\begin{array}{c}170,579,600 \pm \\
96,285,956\end{array}$ & $\begin{array}{c}227,355,430 \pm \\
149,445,948\end{array}$ \\
\hline E. flexuosa* & $\begin{array}{c}38,980,830 \pm \\
8,071,085\end{array}$ & $\begin{array}{c}72,207,500 \pm \\
22,209,603\end{array}$ & $\begin{array}{c}47,062,300 \pm \\
15,861,707\end{array}$ & $\begin{array}{c}73,166,613 \pm \\
21,973,470\end{array}$ \\
\hline Muriceopsis flavida* & $\begin{array}{c}40,904,226 \pm \\
27,271,051\end{array}$ & $\begin{array}{c}61,752,115 \pm \\
30,872,926\end{array}$ & $\begin{array}{c}71,358,000 \pm \\
28,896,058\end{array}$ & $\begin{array}{c}181,226,667 \pm \\
80,268,316\end{array}$ \\
\hline Pseudoplexaura spp. ${ }^{4}$ & $\begin{array}{c}12,694,415 \pm \\
8,835,166\end{array}$ & $\begin{array}{c}34,960,192 \pm \\
20,849,658\end{array}$ & $\begin{array}{c}13,252,200 \pm \\
12,104,263\end{array}$ & $\begin{array}{c}36,811,667 \pm \\
17,624,464\end{array}$ \\
\hline P. porosa & $\begin{array}{c}1,795,170 \pm \\
1,406,924\end{array}$ & $\begin{array}{c}15,029,615 \pm \\
12,218,382\end{array}$ & $\begin{array}{c}45,023,500 \pm \\
34,347,016\end{array}$ & $\begin{array}{c}65,859,086 \pm \\
31,928,218\end{array}$ \\
\hline Pterogorgia anceps* & $\begin{array}{c}384,679 \pm \\
431,954\end{array}$ & $\begin{array}{c}1,633,654 \pm \\
1,529,584\end{array}$ & $\begin{array}{c}1,019,400 \pm \\
783,155\end{array}$ & $\begin{array}{c}4,841,237 \pm \\
5,711,015\end{array}$ \\
\hline P. guadalupensis & $\begin{array}{c}897,585 \pm \\
815,207\end{array}$ & $\begin{array}{c}1,797,019 \pm \\
1,550,504\end{array}$ & $\begin{array}{c}169,900 \pm \\
337,117\end{array}$ & $\begin{array}{c}365,376 \pm \\
437,514\end{array}$ \\
\hline Total abundance (purple) & $\begin{array}{c}609,203,698 \pm \\
236,442,539\end{array}$ & $\begin{array}{c}\overline{1,040,147,404 \pm} \\
502,318,282\end{array}$ & $\begin{array}{c}\overline{1,162,455,800 \pm} \\
516,424,711\end{array}$ & $\begin{array}{c}1,557,964,731 \pm \\
737,790,843\end{array}$ \\
\hline \multicolumn{5}{|l|}{ Not targeted } \\
\hline A. americana & $\begin{array}{c}539,192,075 \pm \\
125,201,041\end{array}$ & $\begin{array}{c}478,170,481 \pm \\
82,948,559\end{array}$ & $\begin{array}{c}600,766,400 \pm \\
119,118,372\end{array}$ & $\begin{array}{c}597,573,011 \pm \\
95,566,345\end{array}$ \\
\hline Gorgonia ventalina & $\begin{array}{c}241,835,019 \pm \\
66,173,864\end{array}$ & $\begin{array}{c}227,241,250 \pm \\
77,682,730\end{array}$ & $\begin{array}{c}390,090,400 \pm \\
107,499,242\end{array}$ & $\begin{array}{c}370,948,333 \pm \\
96,755,309\end{array}$ \\
\hline P. kuna ${ }^{4}$ & nd & $\begin{array}{c}4,410,865 \pm \\
7,415,976\end{array}$ & $\begin{array}{c}1,868,900 \pm \\
1,541,617\end{array}$ & $\begin{array}{c}822,098 \pm \\
813,253\end{array}$ \\
\hline P. grisea & $\begin{array}{c}4,103,245 \pm \\
1,712,921\end{array}$ & $\begin{array}{c}10,945,481 \pm \\
5,411,117\end{array}$ & $\begin{array}{c}9,174,600 \pm \\
1,541,617\end{array}$ & $\begin{array}{c}16,715,968 \pm x \\
813,253\end{array}$ \\
\hline Total abundance (not targeted) & $\begin{array}{c}\overline{785,130,340 \pm} \\
193,087,825\end{array}$ & $\begin{array}{c}720,768,077 \pm \\
193,087,825\end{array}$ & $\begin{array}{c}\overline{1,001,900,300 \pm} \\
234,466,637\end{array}$ & $\begin{array}{c}986,059,409 \pm \\
199,487,414\end{array}$ \\
\hline $\begin{array}{l}\text { Total octocoral abundance } \\
\text { (all groups) }\end{array}$ & $\begin{array}{l}1,474,732,000 \pm \\
466,154,007\end{array}$ & $\begin{array}{c}1,911,048,269 \pm \\
772,473,357\end{array}$ & $\begin{array}{c}2,302,994,500 \pm \\
831,165,953\end{array}$ & $\begin{array}{c}2,742,971,559 \pm \\
831,165,953\end{array}$ \\
\hline
\end{tabular}

Includes the taxa $M$. elongata, $M$. laxa, and $M$. muricata

Includes the taxa A. acerosa, A. bipinnata, A. elisabethae, A. kallos, and A. rigida. Although A. acerosa can be yellowgolden in color and is included in both the purple and other collector categories, $>99 \%$ of colonies encountered are purple and are thus included in the purple category.

Includes the taxa E. calyculata, E. fusca, E. knighti, E. mammosa, E. palmeri, E. succinea and E. tournefort

${ }^{4}$ Includes the taxa P. flagellosa, $P$. wagenaari, and unidentifiable Pseudoplexaura colonies

${ }^{5}$ Plexaura kuna was not distinguished from Eunicea flexuosa, then known as Plexaura flexuosa, during 1999-2002.

colonies generally $7 \mathrm{~m}$ apart. Several hundred colonies can be collected in a single dive. Populations of these two species may serve as important habitat for other marine life, but little informa- tors have observed morphological differences between $S$. exserta colonies in Palm Beach County, where colonies are short and rigid, with those in MiamiDade County, where colonies are tall and flexible. Growth and regeneration rates of $S$. exserta would be interesting to obtain related to collection methods (e.g., fragmentation for Eco-Gorgs ${ }^{\circledR}$ ), but there is no evidence that current collection levels are negatively affecting populations of these two species.

\section{Population Abundance Estimates}

Benthic surveys for octocorals conducted in the Florida Keys during the past 15 years provide habitat-specific density and population abundance estimates. Time series data from 19992014 for octocoral taxa are available for the upper Florida Keys, representing the longest time series available for density (Fig. 12, Table 9) and abundance data (Fig. 13, Table 10). Total abundance for collected species in the Florida Keys is presented for 2009, the most recent sampling that included the entire Florida Keys from northern Biscayne National Park to southwest of Key West (Table 11). The surveys were conducted as part of a Florida Keys-wide monitoring and assessment program designed to evaluate benthic community structure nearshore to offshore, among different habitat types, and inside and outside of marine protected areas (Miller et al., 2002; Smith et. al., 2011). However, many nearshore locations used by marine life collectors, such as tidal channels, bridge pilings, and Florida Bay or Biscayne Bay octocoral patches, were not sampled as part of this program. Among the 47 species recorded in the Keys-wide surveys, population densities and abundances are presented for 15 species (Fig. 11) that represent those collected in the octocoral fishery (Table 12). Species are also divided for comparison into the "other, purple, and red" groups reported by collectors. Species from the "red" group are found at depths outside of the range targeted in Florida Keys-wide benthic surveys (< $15 \mathrm{~m}$ depth), so data are unavailable for these species. 
In the upper Florida Keys, total octocoral population numbers for both "other" and "purple" groups have increased significantly during the last 15 years (Table 10), from over 80 million colonies in 1999-2002 (combined) to almost 200 million in 2014 for octocorals in the "other," category, and from over 600 million to more than 1.5 billion in 2014 for octocorals in the "purple category." In 2009 in the upper Florida Keys, totals for the "other" and "purple" categories were approximately 140,000 and just over 1.4 billion, respectively. Total numbers for colonies Florida Keys-wide in 2009 for "other" and "purple" was estimated at just over 500 million and nearly 2 billion colonies, respectively (Table 11). While the threshold number of 70,000 colonies allowed for collecting has never been exceeded, this threshold represents $0.004 \%$ of total octocoral numbers for collected species as determined in 2009. The actual number of colonies reported by collectors in 2009 was 16,053 for "other" and 19,228 for "purple." When compared to the total numbers of octocorals in the natural population for each group, the percentages are $0.003 \%$ and $0.001 \%$, respectively for "other" and "purple" categories (Fig. 13). Population estimates at the individual species level are potentially more relevant to management interests, but these group estimates provide a first-order assessment that documents the large number of octocorals in the Florida Keys and the relatively miniscule numbers collected in the octocoral fishery. Since genera or species level data are not reported by collectors, estimates of relative percentages collected by species are not explicitly possible, although there is now a better understanding of the species collected in each species color group (Table 2).

For the "red" species found in deeper water ( $>20 \mathrm{~m}$ depth), anecdotal evidence from collectors indicates that large patches of Diodogorgia nodulifera and Swiftia exserta exist in Palm Beach County at depths of 18-45 m and in Miami-Dade County at 25-30 $\mathrm{m}$. The patches are apparently dense and persistent. One collector reported

Table 11.-Octocoral abundance estimates (total colonies $\pm 95 \% \mathrm{Cl}$ ) for sampled hard-bottom and coral reef habitats from northern Biscayne National Park to east of the Marquesas Keys, Florida Keys, during 1999-2009. The most highly valued octocoral species or genera targeted are indicated with an asterisk (*) and are further divided by color group (i.e. purple, red, and other). $\mathrm{nd}=$ no data. Note that octocorals in the red collector group (e.g. Diodogorgia, Ellisella, Iciliogorgia, Leptogorgia, Nicella, and Swiftia) were not encountered during these surveys.

\begin{tabular}{|c|c|c|c|}
\hline Octocoral taxa/collector group & $1999-2002$ & 2005 & 2009 \\
\hline \multicolumn{4}{|l|}{ Other species group } \\
\hline Diodogorgia nodulifera* & nd & nd & nd \\
\hline Muricea spp. ${ }^{* 1}$ & $\begin{array}{c}114,466,278 \pm \\
23,345,596\end{array}$ & $\begin{array}{c}229,332,813 \pm \\
44,812,261\end{array}$ & $\begin{array}{c}270,783,127 \pm \\
54,530,487\end{array}$ \\
\hline M. elongate & $\begin{array}{c}54,896,155 \pm \\
13,416,666\end{array}$ & $\begin{array}{c}129,844,550 \pm \\
23,802,005\end{array}$ & $\begin{array}{c}149,545,171 \pm \\
30,493,430\end{array}$ \\
\hline M. muricata & $\begin{array}{c}59,403,547 \pm \\
10,601,445\end{array}$ & $\begin{array}{c}98,981,708 \pm \\
20,419,537\end{array}$ & $\begin{array}{c}121,237,956 \pm \\
24,037,057\end{array}$ \\
\hline M. pinnata & nd & nd & nd \\
\hline Plexaura homomalla & $\begin{array}{c}51,131,235 \pm \\
13,974,304\end{array}$ & $\begin{array}{c}90,685,145 \pm \\
24,536,639\end{array}$ & $\begin{array}{c}71,650,109 \pm \\
23,179,909\end{array}$ \\
\hline Plexaurella spp.* & $\begin{array}{c}91,941,210 \pm \\
22,984,308\end{array}$ & $\begin{array}{c}133,700,718 \pm \\
35,218,576\end{array}$ & $\begin{array}{c}61,457,283 \pm \\
28,670,931\end{array}$ \\
\hline Pterogorgia citrina* & $\begin{array}{c}47,353,292 \pm \\
16,364,273\end{array}$ & $\begin{array}{c}58,926,251 \pm \\
36,218,576\end{array}$ & $\begin{array}{c}61,457,283 \pm \\
28,670,931\end{array}$ \\
\hline$\overline{\text { Total abundance (other) }}$ & $\begin{array}{c}304,892,015 \pm \\
77,668,481\end{array}$ & $\begin{array}{c}512,644,926 \pm \\
140,749,768\end{array}$ & $\begin{array}{c}502,066,548 \pm \\
130,939,795\end{array}$ \\
\hline \multicolumn{4}{|l|}{ Purple species group } \\
\hline Antillogorgia spp. ${ }^{* 2}$ & $\begin{array}{c}531,244,061 \pm \\
145,690,832\end{array}$ & $\begin{array}{c}717,169,257 \pm \\
188,139,742\end{array}$ & $\begin{array}{c}834,535,525 \pm \\
274,982,791\end{array}$ \\
\hline Briareum asbestinum $^{*}$ & $\begin{array}{c}76,833,389 \pm \\
28,820,534\end{array}$ & $\begin{array}{c}256,057,667 \pm \\
91,398,237\end{array}$ & $\begin{array}{c}202,025,444 \pm \\
77,658,165\end{array}$ \\
\hline Eunicea spp. ${ }^{3}$ & $\begin{array}{c}389,162,980 \pm \\
81,019,210\end{array}$ & $\begin{array}{c}547,578,643 \pm \\
198,535,609\end{array}$ & $\begin{array}{c}416,116,429 \pm \\
124,077,575\end{array}$ \\
\hline E. flexuosa* & $\begin{array}{c}185,228,376 \pm \\
23,125,728\end{array}$ & $\begin{array}{c}266,279,655 \pm \\
40,101,745\end{array}$ & $\begin{array}{c}190,583,527 \pm \\
35,674,286\end{array}$ \\
\hline Muriceopsis flavida* & $\begin{array}{c}62,159,541 \pm \\
27,764,515\end{array}$ & $\begin{array}{c}91,947,753 \pm \\
31,754,005\end{array}$ & $\begin{array}{c}91,947,753 \pm \\
32,270,055\end{array}$ \\
\hline Pseudoplexaura spp. ${ }^{4}$ & $\begin{array}{c}69,971,429 \pm \\
25,084,018\end{array}$ & $\begin{array}{c}179,075,503 \pm \\
36,586,142\end{array}$ & $\begin{array}{c}35,070,418 \pm \\
14,600,796\end{array}$ \\
\hline P. porosa & $\begin{array}{c}51,464,030 \pm \\
16,649,265\end{array}$ & $\begin{array}{c}81,975,495 \pm \\
24,831,817\end{array}$ & $\begin{array}{c}155,932,898 \pm \\
51,472,259\end{array}$ \\
\hline Pterogorgia anceps ${ }^{*}$ & $\begin{array}{c}2,954,689 \pm \\
1,725,127\end{array}$ & $\begin{array}{c}2,801,050 \pm \\
2,158,399\end{array}$ & $\begin{array}{c}1,964,400 \pm \\
1,092,191\end{array}$ \\
\hline P. guadalupensis & $\begin{array}{c}20,421,201 \pm \\
35,917,649\end{array}$ & $\begin{array}{c}4,565,968 \pm \\
2,816,245\end{array}$ & $\begin{array}{c}1,247,261 \pm \\
824,147\end{array}$ \\
\hline$\overline{\text { Total abundance (purple) }}$ & $\begin{array}{c}, 389,439,696 \pm \\
385,796,878\end{array}$ & $\begin{array}{c}2,147,450,990 \pm \\
616,321,940\end{array}$ & $\begin{array}{c}2,147,450,990 \pm \\
612,652,265\end{array}$ \\
\hline \multicolumn{4}{|l|}{ Not targeted } \\
\hline A. americana & $\begin{array}{c}1,112,059,940 \pm \\
147,609,769\end{array}$ & $\begin{array}{c}1,137,085,998 \pm \\
141,090,463\end{array}$ & $\begin{array}{c}1,392,367,210 \pm \\
154,299,778\end{array}$ \\
\hline Gorgonia ventalina & $\begin{array}{c}437,122,788 \pm \\
75,248,774\end{array}$ & $\begin{array}{c}472,620,974 \pm \\
89,265,986\end{array}$ & $\begin{array}{c}679,304,335 \pm \\
118,314,731\end{array}$ \\
\hline P. kuna ${ }^{4}$ & nd & $\begin{array}{c}5,501,538 \pm \\
7,493,196\end{array}$ & $\begin{array}{c}2,469,016 \pm \\
1,651,251\end{array}$ \\
\hline P. grisea & $\begin{array}{c}17,072,178 \pm \\
3,994,974\end{array}$ & $\begin{array}{c}34,026,481 \pm \\
8,087,015\end{array}$ & $\begin{array}{c}20,671,706 \pm \\
7,161,260\end{array}$ \\
\hline$\overline{\text { Total abundance (not targeted) }}$ & $\begin{array}{c}1,566,254,906 \pm \\
226,853,517\end{array}$ & $\begin{array}{c}1,649,234,991 \pm \\
245,936,660\end{array}$ & $\begin{array}{c}2,094,812,268 \pm \\
281,427,021\end{array}$ \\
\hline $\begin{array}{l}\text { Total octocoral abundance } \\
\text { (all groups) }\end{array}$ & $\begin{array}{c}2,094,812,268 \pm \\
273,610,977\end{array}$ & $\begin{array}{c}4,759,804,279 \pm \\
377,877,699\end{array}$ & $\begin{array}{c}4,896,380,423 \pm \\
406,830,115\end{array}$ \\
\hline
\end{tabular}

${ }^{1}$ Includes the taxa M. elongata, $M$. laxa, and M. muricata

${ }^{2}$ Includes the taxa A. acerosa, A. bipinnata, A. elisabethae, A. kallos, and A. rigida. Although A. acerosa can be yellowgolden in color and is included in both the purple and other collector categories, $>99 \%$ of colonies encountered are purple and are thus included in the purple category.

${ }^{3}$ Includes the taxa E. calyculata, E. fusca, E. knighti, E. mammosa, E. palmeri, E. succinea and E. tourneforti

${ }^{4}$ Includes the taxa P. flagellosa, P. wagenaari, and unidentifiable Pseudoplexaura colonies

${ }^{5}$ Plexaura kuna was not distinguished from Eunicea flexuosa, then known as Plexaura flexuosa, during 1999-2002.

that he returns to the same general area several times per year and easily find hundreds of colonies on a single dive. In fact, surveys along much of the southeastern coast of the Unit- ed States indicate that $S$. exserta is broadly distributed along the edge of the continental shelf, and deeper. Although limited information is available from the literature on deeper water oc- 
Table 12.-Octocorals surveyed in fishery independent surveys that are also targeted by octocoral collectors.

\begin{tabular}{|c|c|c|}
\hline Species goup & Scientific name & Collector common name \\
\hline Other & $\begin{array}{l}\text { Antillogorgia acerosa } \\
\text { Muricea elongata } \\
\text { Muricea muricata } \\
\text { Plexaura homomalla } \\
\text { Plexaurella fusifera } \\
\text { Plexaurella nutans } \\
\text { Pterogorgia citrina }\end{array}$ & $\begin{array}{l}\text { golden plume gorgonian } \\
\text { orange spiny sea rod/rusty gorgonian } \\
\text { spiny sea fan } \\
\text { black sea rod } \\
\text { brown tree gorgonian } \\
\text { giant slit pore/large polyp gorgonian } \\
\text { yellow ribbon/yellow sea whip gorgonian }\end{array}$ \\
\hline Purple & $\begin{array}{l}\text { Antillogorgia acerosa } \\
\text { Antillogorgia elisabethae } \\
\text { Antillogorgia kallos } \\
\text { Briareum asbestinum } \\
\text { Eunicea flexuosa } \\
\text { Muriceopsis flavida } \\
\text { Pseudoplexaura porosa } \\
\text { Pterogorgia anceps } \\
\text { Pterogorgia guadalupensis }\end{array}$ & $\begin{array}{l}\text { purple or golden willow gorgonian } \\
\text { purple frilly gorgonian } \\
\text { purple plume/bi-pinnate gorgonian } \\
\text { corky sea finger/sea stalk gorgonian } \\
\text { purple candelabra/swollen knob candelabrum gorgonian } \\
\text { purple brush/bottle brush gorgonian } \\
\text { purple tree gorgonian } \\
\text { purple ribbon/angular sea whip gorgonian } \\
\text { purple blade/flat-blade/grooved-blade sea whip gorgonian }\end{array}$ \\
\hline
\end{tabular}

tocoral taxa, Goldberg (1973) reported $D$. nodulifera comprising approximately $5 \%$ of the total colonies on the outer fore reef off Palm Beach County. $S$. exserta was observed in relatively high abundance at $30 \%$ in the same location and lower in abundance $(1.25 \%)$ inshore.

While collectors are not currently required to report at the species level, population data for each of the 15 species targeted is available (Tables 10 and 11). At the species level, octocoral abundance has increased since 1999 in the upper Florida Keys for all species in the "other" group, except Pterogorgia citrina, which appears relatively stable over the period considered. For the "purple" group, most species have increased or remained stable. Population sizes of Pterogorgia anceps and $P$. guadalupensis increased between 1999 and 2005, then fell in 2009 and increased again in 2014. It is difficult to identify the causes of these fluctuations; however, natural changes in population dynamics can occur, as large colonies break or become detached because of high wave action due to storms. In addition, $B$. asbestinum is more susceptible to bleachingrelated mortality.

Currently, octocoral abundance in the upper Florida Keys is dominated by Antillogorgia species (Fig. 12, Table 10). Three species are particularly prized by marine aquarium hobbyists due to their vibrant purple color: $A$. elisabethae ( 416 million estimated colonies), A. kallos ( $\sim 392$ million colonies), and Muriceopsis flavida ( 181 million colonies). These octocorals are abundant and grow quickly, two traits that suggest that current collection levels probably do not negatively affect these species. In contrast, all three species in the genus Pterogorgia ( $P$. citrina, $P$. anceps, and P. guadalupensis) and Plexaurella fusifera are less abundant (though ranging from hundreds of thousands to tens of millions of colonies), but little is known about whether or not these species are targeted by collectors. If one or more of the Pterogorgia species are brooders, local collection at "hot spots" may affect reproduction and successful recruitment, as Castanaro and Lasker (2003) documented with collection of $A$. elisabethae in the Bahamas. For example, $P$. citrina has a relatively small maximum colony size, and if collectors target the larger fecund colonies or perhaps a color morph (e.g., yellow vs. purple), there may be at least a local negative effect on populations. Despite uncertainties about population estimates for some species, there is nothing in the abundance estimates to suggest that the current collection levels for octocorals is adversely affecting octocoral populations in the Florida Keys.

\section{Fishery Management Recommendations}

Information assembled for this study aimed to address management concerns about the octocoral fishery that were raised by the South Atlantic Fishery Management Council (SAFMC) in a 22 June 2010 memo to NOAA's Southeast Fishery Science
Center (NMFS/SEFSC). Specifically, the SAFMC asked for an "evaluation of octocoral landings and fishery impacts" because octocoral catch data were being used to set Acceptable Biological Catch limits and Overfish limits rather than population data. An additional concern with the octocoral fishery is that a substantial amount of taxonomic uncertainty exists among collectors, wholesalers, and law enforcement. When colonies are identified and lumped by color, rather than by species, information is lost related to life-history traits or ecological function. These are factors that that could potentially affect management strategies.

A goal of this study was to provide the SAFMC and FWC with the best available information to help manage the octocoral fishery, with the least economic impact on the collectors who depend upon this resource for income. The management recommendations are summarized as follows. Based on interviews with collectors and a synthesis of FWC Trip Ticket results, the long-term stability of the octocoral fishery is not likely to significantly change, so there is therefore little concern to be had about the fishery exceeding the 70,000 colonies/ yr threshold. The social dynamics of the aquarium industry to seek colorful, rare, and exotic marine species for home aquaria places octocorals on the low end of the desired list of marine life species. Although some octocoral species are vibrantly colored (e.g., Antillogorgia acerosa, Muriceopsis flavida, Leptogorgia spp.), they are neither rare nor exotic. Species that are collected from deeper habitats (e.g., Swiftia exserta and Diodogorgia spp.) are difficult to keep in good health in home aquaria and are marketed as appropriate for advanced aquarists, thus resulting in minimal demand. Octocorals also do not contribute ecosystem services in home aquaria, such as control and removal of algae and detritus, which also limits demand. In addition, during the last 20 years, octocoral landings have fluctuated slightly or actually decreased. 
Distribution and abundance information obtained from an exhaustive literature search, along with age, growth, population and habitat data, suggests that current information is adequate to describe the populations and the octocoral fishery, making a formal stock assessment probably a low priority. The list of 12 targeted species in original scope of work for this study was expanded to 24 species based on interviews with collectors. Considerable lumping of taxa based upon colony color still occurs. Scientifically, there are genera where additional information on population status and life history information would be academically interesting (e.g., for the genera Muricea, Pterogorgia, and Diodogorgia), but based on the current state of knowledge and collecting levels, this additional information is probably a low priority for informing management needs related to speciesspecific, seasonal, or depth-driven regulation of annual quotas.

The collection of octocorals, below the 70,000 colony per year quota, a level that has never been reached, does not appear to adversely impact octocoral populations. For multiple sampling periods spanning over a decade, the Florida Keys abundance estimates presented for 15 species illustrate that octocoral populations are large (tens of millions to hundreds of millions, per species) and despite some fluctuations that are likely due to natural variation (along with sampling issues and taxonomic questions) are generally increasing. This result provides evidence that current and projected octocoral collection levels are acceptable $(<$ $0.01 \%$ of estimated population sizes) and that no octocoral species is overcollected. The scaling of quotas and landings at finer taxonomic resolution may be desirable to provide further data resolution. Further, the collectors interviewed rotate their collection sites and are selective about removing individual colonies that are size-appropriate and aesthetically pleasing for the aquarium trade. As long as octocoral collection does not increase substantially (e.g., 500 to 1,000 times current levels), natural populations are probably not threatened. These results also suggest that if demand for octocorals were to increase substantially, that the 70,000 colony quota could reasonably be increased, assuming the reason for the increased demand can be rationally evaluated. For example, if demand was to increase, is it based upon one species, one group of species, or spread across all species? In addition, better understanding of collecting methods would be relevant. For example, was demand being met through Eco$\operatorname{gorgs}^{\circledR}$, other fragmentation methods, rotating sites, or something else?

Data collected by FWC through the Trip Ticket program is adequate to understand and manage the octocoral fishery, although FWC has proposed refinements to the reporting criteria beyond the three current octocoral categories. Regional distinctions that separate Florida Keys landings from others in Atlantic Ocean waters would be beneficial for understanding what parts of the Florida Reef Tract are utilized for collecting octocorals, since management reviews are underway in Monroe, Miami-Dade, Broward, and Palm Beach Counties. Collectors who were interviewed indicated that they would like clarification in the reporting methodology for clipped fragments versus whole colonies collected. For example, should three clippings from a single colony be recorded as three colonies or one colony?

Collectors and aquarium hobbyists stated that they would welcome and use a field guide to help with octocoral identification, which would ultimately provide better taxonomic resolution for collected species. A potential benefit to collectors who report at higher taxonomic resolution would be that they could document that their collections are eco-friendly, by linking scientific results presented here that indicate collecting represents an insignificant percentage of the total population. None of these suggestions related to recording additional or better information as part of the Trip Ticket program are needed to benefit or protect the fishery itself. Instead, they might benefit the collectors by helping them to better market octocorals. Additional taxonomic resolution for the Trip Ticket program is not being proposed, as it is not necessary for ensuring sustainability of the octocoral fishery at current levels. While collectors may benefit from the additional data, voluntary participation is recommended.

Information obtained and compiled for this study suggests that additional research is not necessarily needed to better manage the octocoral fishery. While the population biology of deepwater species remains largely unknown, there is no evidence that populations are being adversely affected by the relatively low numbers of colonies collected. Octocoral collection in the Bahamas for the cosmetics industry and the artisanal jewelry trade, for example, previously prompted studies on growth and reproduction of targeted octocoral species to understand the effects of repeated and extensive clear-cutting, sometimes to the point that only holdfasts remained (Morel et al., 1996; Castanaro and Lasker, 2003; Cadena and Sanchez, 2010). In Florida, collection for the aquarium trade dramatically contrasts with that conducted by commercial collectors for the pharmaceutical industry. The selective removal of adult colonies, sub-adult colonies, or branches from adult colonies at current levels does not appear to warrant any change to the current fishery management plan for octocorals.

\section{Acknowledgments}

Funding for this project was provided by the NOAA Coral Reef Conservation Program's Cooperative Agreement with the South Atlantic Fishery Management Council (2011-13). The authors especially thank J. Schull (NOAA Fisheries, SEFSC-Miami Laboratory) and A. David (NOAA Fisheries, SEFSC-Panama City Laboratory) for project guidance and support. M. Bademan, N. Sheridan, and V. Brinkhuis with the Florida Wildlife Research Institute, Fish and Wildlife Conservation Commission, provided helpful reviews. The 
authors also thank the numerous marine life collectors who offered their experience, expertise, and knowledge that were instrumental in helping to elucidate the characteristics of the octocoral fishery. Partial funding for octocoral surveys in the Florida Keys and Dry Tortugas during 1999-2014 was provided to S. L. Miller by NOAA's Coral Reef Conservation Program, and NOAA Grant NA96RU-0260 to the National Undersea Research Center at the University of North Carolina-Wilmington and Nova Southeastern University. Program management and logistical support were provided by the Florida Keys National Marine Sanctuary, NOAA's National Undersea Research Center at UNCW, Biscayne National Park, Dry Tortugas National Park, RSMASUniversity of Miami, and NOAA/ NMFS/SEFSC. Permission to conduct research in the Florida Keys National Marine Sanctuary was obtained under Sanctuary Permits FKNMS-074-98, FKNMS-2009-002, FKNMS-2010-77, and FKNMS-2014-058, and in Biscayne National Park under NPS Permits BISC-2005-SCI-0039 and BISC-2012-SCI-0011.

Much of the available historical life history information for tropical western Atlantic octocorals was compiled initially in the early 1990 s by the University of Miami and The Nature Conservancy's Caribbean Program, under the purview of K. M. Sullivan-Sealey (University of Miami), R. Roca (The Nature Conservancy), and E.C. Peters (George Mason University), with support from The Nature Conservancy's Latin America and Caribbean Science Program, The Nature Conservancy's Florida Keys Initiative, the Smithsonian Institution, and the John G. and Catharine T. MacArthur Foundation. M. Chiappone would particularly like to thank the support, insights, and mentoring by Dr. K. Sullivan-Sealey, as well as the inspirational work on octocorals by S. Cairns and the late F. M. Bayer of the Smithsonian Institution.

\section{Literature Cited}

Adams C, S. Larkin, and D. Lee. 2001. Volume and value of marine ornamentals collected in
Florida, 1990-1998. Aquarium Sci. Conserv. 3:25-36.

American Pet Products Association. 2014. Retrieved from americanpetproducts.org/press_ industrytrends.asp, Accessed 20 Nov. 2014.

Antonius, A., A. Weiner, J. Halas, and E. Davidson. 1978. Looe Key Reef resource inventory. Florida Reef Foundation, Homestead, Fla., 51

Bayer, F. M. 1961. Shallow-water Octocorallia of the West Indian Region. A manual for marine biologists. Martinus Nijhoff, The Hague, Netherlands, 373 p.

1981. Key to the genera of Octocorallia exclusive of the Pennatulacea, with diagnoses of new taxa. Proc. Biol. Soc. Wash. 94:902-947.

Beaver, C., S. Brooke, M. Callahan, D. Johnson, J. Kidney, S. Kupfner, J. W. Porter, M. Meyers, S. Wade, and J. Wheaton. 2006. Coral Reef Evaluation and Monitoring Project (CREMP), 2005 Executive Summary, EPA Steering Committee Meeting June 2006. Florida Fish and Wildl. Conserv. Commiss., St. Petersburg, FL and the Univ. Georgia, Athens, GA, $10 \mathrm{p}$.

Beiring, E. A., and H. R. Lasker. 2000. Egg production by colonies of a gorgonian coral. Mar. Ecol. Prog. Ser. 196:169-177.

Benayahu, Y. 1991. Reproduction and developmental pathways of Red Sea Xeniidae (Octocorallia: Alcyonacea). Hydrobiologia 216:125-130.

Y. Achituv, and T. Berner. 1989. Metamorphosis of an octocoral primary polyp and its infection by algal symbiosis. Symbiosis 7:159-169.

and Y. Loya. 1984. Life history studies on the Red Sea soft coral Xenia macrospiculata Gohar, 1940. I. Annual dynamics of gonadal development. Biol. Bull. 166:32-43.

D. Weil, and Z. Malik. 1992. Entry of algal symbionts into oocytes of the coral Litophyton arboretum. Tissue and Cell 24:473-482.

Birkeland, C. 1974. The effect of wave action on the population dynamics of Gorgonia ventalina Linnaeus. In F. M. Bayer and A. J. Weinheimer (Editors), Prostaglandins from Plexaura homomalla: ecology, utilization and conservation of a major medical marine resource, a symposium, p. 115-126. Univ. Miami Press, Coral Gables, Fla.

Blair, S., and B. Flynn. 1989. Biological monitoring of hard bottom reef communities off Dade County Florida: community description. In Proceedings of the American Academy of Underwater Sciences 9th Annual Scientific Diving Symposium, p. 9-24. Woods Hole, Mass.

Bohnsack, J. A., D. E. Harper, and D. B. McClellan. 1994. Fisheries trends from Monroe County, Florida. Bull. Mar. Sci. 54(3):982-1018.

Brazeau, D. A., and H. R. Lasker. 1990. Sexual reproduction and external brooding by the Caribbean gorgonian Briareum asbestinum. Mar. Biol. 104:465-474.

Bruck, T. B., W. M. Bruck, L. Z. SantiagoVazquez, P. J. McCarthy, and R. G. Kerr. 2007. Diversity of the bacterial communities associated with the azooxanthellate deep water octocorals Leptogorgia minimata, Iciligorgia schrammi, and Swiftia exertia.
Mar. Biotech. 9:561-576. (doi: https://doi org/10.1007/s10126-007-9009-1).

Brusca, R. C., and G. J. Brusca. 2003. Invertebrates, 2nd ed. Sinauer Associates, Sunderland, MA. 936 p.

Bundy, G. 1985. Nonmammalian sources of eicosanoids. Advances in Prostaglandin, Thromboxane, and Leukotriene Research 14:229-262.

Cadena, N. J., and J. A. Sánchez. 2010. Colony growth in the harvested octocoral Pseudopterogorgia acerosa in a Caribbean coral reef. Mar. Ecol. 31(4):566-573. doi: 10.1111/j.1439-0485.2010.00397.x.

Cairns, S. D. 1977. Guide to the commoner shallow-water gorgonians (sea whips, sea feathers and sea fans) of Florida, the Gulf of Mexico, and the Caribbean region. In $\mathrm{G}$. Voss (Editor), Sea Grant Field Guide Series No. 6, Univ. Miami Sea Grant Prog., Miami, Fla., 74 p.

A. Brinckmann-Voss, C. B. Castro, D. G. Fautin, P. R. Pugh, C. E. Mills, W. C. Jaap, M. N. Arai, S. H. D. Haddock, and D. M. Opresko. 2002. Common and scientific names of aquatic invertebrates from the United States and Canada: Cnidaria and Ctenophora, 2nd ed. Amer. Fish. Soc. Spec. Publ. 28, Bethesda, Md., 155 p.

Cary, L. R. 1914. Observations upon the growth rate and oecology of gorgonians. Carnegie Inst. Wash Publ 5:79-90.

Castanaro, J., and H. R. Lasker. 2003. Colony growth responses of the Caribbean octocoral, Pseudopterogorgia elisabethae, to harvesting. Invert. Biol. 122:299-307.

Chiappone, M., and K. M. Sullivan. 1994. Patterns of coral abundance defining nearshore hard-bottom communities of the Florida Keys. Fla. Sci. 57(3):108-125. and K. M. Sullivan. 1997. Rapid assessment of reefs in the Florida Keys: Results from a synoptic survey. Proc Eighth Intl Coral Reef Symp Panama 2:1,509-1,514.

Cochran, W. G. 1977. Sampling techniques. 3rd ed. Wiley, N.Y., 428 p.

Colin, P. I. 1978. Caribbean reef invertebrates and plants. THF Publications, Hong Kong, $512 \mathrm{p}$.

Davis, G. E. 1982. A century of natural change in coral distribution at Dry Tortugas: A comparison of reef maps from 1881 to 1976 Bull. Mar. Sci. 32(2):608-623.

Derr, M. 1992. Raiders of the reef. Audubon (March/April):49-56.

Fabricus, K. and P. Alderslade. 2001. Soft corals and sea fans. A comprehensive guide to the shallow-water genera of the central-west Pacific, the Indian Ocean and the Red Sea. Australian Inst. Mar. Sci., Townsville, 264 p.

Faricius, K. E., and D. W. Klumpp. 1995. Widespread mixotrophy in reef-inhabiting soft corals: the influence of depth, and colony expansion and contraction on photosynthesis. Mar. Ecol. Prog. Ser. 125:195-204.

A. Genin, and Y. Benayahu. 1995. Flow-dependent herbivory and growth in zooxanthellae-free soft corals. Limnol Oceanogr. 40:1290-1301.

Fitzsimmons, K., and P. Hallock-Muller. 1996. Cycles of gonadal development in six common gorgonians from Biscayne National Park in the Northern Florida Keys Department of Marine Science. M.Sc. Thesis, University of South Florida, St. Petersburg, FL, 61 p. 
Fitzsimmons-Sosa, K., P. Hallock, J. Wheaton, K. Hackett, and M. Callahan. 2004. Annual cycles of gonadal development of six common gorgonians from Biscayne National Park, Florida, USA. Carib. J. Sci. 40:144-150

Florida Fish and Wildlife Conservation Commission (FWC). 2006. Southeast Florida coral reef evaluation and monitoring project: 2005 year 3 final report. FWC and the National Coral Reef Institute, Nova Southeastern University Oceanographic Center, Ft. Lauderdale, FL.

2014. Commercial fisheries landings in Florida. Retrieved from myfwc.com/ research/saltwater/fishstats/commercial-fisheries/landings-in-florida, Accessed 13 October 2014

Gilliam, D. 2012. Southeast Florida coral reef evaluation and monitoring project 2011 year 9 final report. Florida DEP Report \#RM085, Miami Beach, FL. 52 p.

J. Vernacchio, and R. Dodge. 2003. Nurseries for reef fishery habitat. Final Programmatic Report, National Fish and Wildlife Foundation, Washington, D.C., 33 p. R. Dodge, R. Spieler, L. Jordan, and J. Monty. 2004a. Marine biological monitoring in Broward County Florida: Year 4 annual report. Broward County Tech. Rep. 04-01, Dania Beach, Fla., 92 p.

B. Ettinger, D. Fahy, E. Fahy, S. Gill, J. Monty, L. Shuman, and B. Walker. 2004b. Southeast Florida coral reef evaluation and monitoring project year 1 report. Florida Fish and Wildlife Commission, Florida Marine Research Institute, St. Petersburg, Fla., $12 \mathrm{p}$.

and J. Walczak. 2007. Marine biological monitoring in Broward County, Florida: Year 6 annual report. Broward County Environmental Protection Department, Biological Resources Division, Ft. Lauderdale, Fla., $93 \mathrm{p}$.

Goffredo, S., and H. R. Lasker. 2008. An adaptive management approach to an octocoral fishery based on the Beverton-Holt model. Coral Reefs 27:751-761. doi: 10.1007/ s00338-008-0391-6.

Goldberg, W. M. 1973. The ecology of coral-octocoral communities off the southeast Florida coast: Geomorphology, species composition, and zonation. Bull. Mar. Sci. 23:465-488.

Gotelli, N. J. 1988. Determinants of recruitment, juvenile growth, and spatial distribution of a shallow-water gorgonian. Ecology 69(1):157-166

Gutierrez-Rodrigues, C., and H. R. Lasker. 2004. Microsatellite variation reveals high levels of genetic variability and population structure in the gorgonian coral Pseudopterogorgia elisabethae across the Bahamas. Mol. Ecol. 13:2211-2221.

Harvell, C. D., and T. H. Suchanek. 1987. Partial predation on tropical gorgonians by Cyphoma gibbosum (Gastropoda). Mar. Ecol. Prog. Ser. 38:37-44.

Hiller, G. 2006. "Frag" of the month: Gorgonian propagation techniques. Retrieved from Reefkeeping: reefkeeping.com/issues/2006-10/ fotm/index.php, Accessed 20 Nov. 2014.

Ho, L. 2011. Peppermint angelfish video. Retrieved from Advanced Aquarist: advancedaquarist.com/blog/peppermint-angelfish-video. Accessed 20 Nov. 2014.
Humann, P. 1993. Reef coral identification: Florida Caribbean Bahamas, including marine plants. New World Publ., Jacksonville, Fla., $239 \mathrm{p}$

Japp, W. C. 1984. The ecology of South Florida coral reefs: A community profile. Dep. Interior, U.S. Fish Wildl. Serv., Rep. FWS/OBS$82 / 08,138 \mathrm{p}$

and J. L. Wheaton. 1975. Observations of Florida reef corals treated with fishcollecting chemicals. Fla. Mar. Res. Publ. $10: 1-17$

Jackson, J. B. C. 1991. Adaptation and diversity of reef corals. Bioscience 41(7):475-482

Jensen, P. R., C. D. Harvell, K. Wirtz, and W. Fenical. 1996. Antimicrobial activity of extracts of Caribbean gorgonian corals. Mar. Biol. 125:411-419.

Joshi, S. 2010. Feature Article: Quantitative comparison of lighting technologies: metal halide, T5 fluorescent and LED. Retrieved from Advanced Aquarist at advancedaquarist.com/2010/2/aafeature2, Accessed 20 Nov. 2014

Kahng, S. E., Y. Benayahu, and H. R. Lasker. 2011. Sexual reproduction in octocorals. Mar. Ecol. Prog. Ser. 443:265-283, doi: 10.3354/ meps09414.

Kapela, W., and H. R. Lasker. 1999. Size-dependent reproduction in the Caribbean gorgonian Pseudoplexaura porosa. Mar. Biol. 135:107-114

Kinzie, R. A., III. 1973. The zonation of West Indian gorgonians. Bull. Mar. Sci. 23(1):93-155.

Kissling, D. L. 1977. Coral reefs in the lower Florida Keys: A preliminary report. p. 209 215 In Field guide to some carbonate rock environments: Florida Keys and western Bahamas. Multer HG (Ed.), New Edition, Dubuque, IA

Larkin, S., C. Adams, R. Degner, D. Lee, and J. Milon. 2001. An economic profile of Florida's marine life industry. Sea Grant Tech Pap No. 113. USDOC, NOAA, Natl. Sea Grant Prog., Gainesville, Fla., 67 p.

Lasker, H. R. 1988. The incidence and rate of vegetative propagation among coral reef alcyonarians. Proc. 6th Intl. Coral Reef Symp., Townsville 2:763-768.

2005. Gorgonian mortality during a thermal event in the Bahamas. Bull. Mar. Sci. 76:155-162.

and M. A. Coffroth. 1983. Octocoral distributions at Carrie Bow Cay, Belize. Mar. Ecol. Prog. Ser. 12:21-28.

and K. Kim. 1996. Larval development and settlement behavior of the gorgonian coral Plexaura kuna (Lasker, Kim and Coffroth). J. Exp. Mar. Biol. Ecol. 207:161-175

and K. M. Stewart. 1992. Gamete dilution and fertilization success among broadcast spawning octocorals. Proc. Seventh Int. Coral Reef Symp. Guam 1:476-483.

Levy, J. M., M. Chiappone, and K. M. Sullivan. 1996. Invertebrate infauna and epifauna of the Florida Keys and Florida Bay. Site Characterization for the Florida Keys National Marine Sanctuary and Environs, Volume V. The Preserver of the Farley Court of Publishes, Zenda, WI, $166 \mathrm{p}$.

Lewis, J. C., and E. Von Wallis. 1991. The function of surface sclerites in gorgonians (Coelenterata, Octocorallia). Biol. Bull. $181: 275-288$.
Look, S. A., W. Fenical, R. S. Jacobs, and J Clardy. 1986. The pseudopterosins: anti-inflammatory and analgesic natural products from the sea whip Pseudopterogorgia elisabethae. Proc. Natl. Acad. Sci. 83:6238-6240.

Lorance, E. 1977. I. Isolation, Identification, and Structure Determination of Compounds Isolated from the Gorgonians, Pterogorgia Anceps and Pterogorgia guadalupensis. II. Investigation of a Novel Method for the Synthesis of Butyrolactones. III. Investigation of the Thermal Decomposition of 1,1,3,3-Tetraoxo-2, 2-Diphenyl-1, 3-Dithiane. Ph.D. Dissertation, University of Oklahoma, Accessed through University Microfilms International, Ann Arbor, Mich, 125 p.

Luty, A. 2014. Aquarium frontiers: coral reef tanks in Germany. Retrieved from Fish Channel: fishchannel.com/saltwater-aquariums aquarium-frontiers/germany.aspx, Accessed 20 Nov. 2014

Menzel, L. P., B. Stein, and C. H. Bigger. 2012. Morphology and histology of the gorgonian coral Swiftia exserta. Integrative and Comparative Biol. 52:E120-E120.

Miller, S. L., D. W. Swanson, and M. Chiappone. 2002. Multiple spatial scale assessment of coral reef and hard-bottom community structure in the Florida Keys National Marine Sanctuary. Proc. Ninth Int. Coral Reef Symp. Bali 1:69-74

Morel, J., C. Rondi-Costanzo, and D. Ugolini. 1996. Corallo di leri - Corallo di Oggo. Atti Del Convegno, Ravello, Villa Rufolo, 13-15 Dicembre 1996 Centro Universitario Europeo Per I Beni Culturali. Ravello.

Moyer, R. P., B. Riegl, K. Banks, and R. E. Dodge. 2003. Spatial patterns and ecology of benthic communities on a high-latitude South Florida (Broward County, USA) reef system. Coral Reefs 22:447-464.

Murdoch, G. R. 1978. Circulation and digestion of food in the gastrovascular system of gorgonian octocorals (Cnidaria: Anthozoa). Bull. Mar. Sci. 28(2):363-370.

Nagelkerken, I., K. Buchan, G. W. Smith, K. Bonair, P. Bush, J. Garzon-Ferreira, L. Botero, P Gayle, C. D. Harvell, C. Heberer, K. Kim C. Pertrovic, L. Pors, and P. Yoshioka. 1997. Widespread disease in Caribbean sea fans: II. Patterns of infection and tissue loss. Mar. Ecol. Prog. Ser. 160:255-263.

Olano, C. T., and C. H. Bigger. 2000. Phagocytic activities of the gorgonian coral Swiftia exserta. J. Invert. Path. 76(3):176-184.

Opresko, D. M. 1973. Abundance and distribution of shallow-water gorgonians in the area of Miami, Florida. Bull. Mar. Sci. 23:535-558

Patton, W. K. 1972. Studies on the animal symbionts of the gorgonian coral, Leptogorgia virgulata (Lamarck). Bull. Mar. Sci. 22:419-431.

Pawlik, J. R., and W. Fenical. 1992. Chemical defense of Pterogorgia anceps, a Caribbean gorgonian coral. Mar. Ecol. Prog. Ser. 87:183-188

Preston, E. M., and J. L. Preston. 1975. Ecological structure in a West Indian gorgonian fauna. Bull. Mar. Sci. 25(2):248-258.

Rhyne, A., and M. Tlusty. 2012. Trends in the marine aquarium trade: the influence of global economics and technology. Int. J. Bioflux Soc 5:99-102.

R. Rotjan, A. Bruckner, and M. Tlusty. 2009. Crawling to collapse: Ecologi- 
cally unsound ornamental invertebrate fisheries. PLoS ONE 4(12). (doi: https://doi. org/10.1371/journal.pone.0008413.)

Ribes, M., R. Coma, and J. M. Gili. 1998. Heterotrophic feeding by gorgonian corals with symbiotic zooxanthella. Limnol. Oceanogr. 43:1170-1179.

Ritson-Williams, R. 2010. Surface brooding in the Caribbean gorgonian Pterogorgia anceps. Coral Reefs, 29:437-437.

Robins, C. R. 1976. Aquarium fish hobby: Its impact on the economy and environment of southern Florida. Proc. Gulf Carib. Fish Inst. 28:83-86.

Rodriguez, A., and C. Ramirez. 1994. Further butenolides from the Caribbean Octocoral Pterogorgia citrina. J. Nat. Prod. 57(3): 339-347.

Ruzicka, R., K. Semon, M. A. Colella, V. Brinkhuis, and others. 2009. CREMP 2009 final report. Fish Wildl. Res. Inst., Fl. Fish Wildl. Conserv. Commiss., St. Petersburg, Fl.

Sanchez, J. A., and H. H. Wirshing. 2005. A field key to the identification of tropical western Atlantic zooxanthellate octocorals (Octocorallia: Cnidaria). Carib. J. Sci. 41:508-522.

Sathe, M., D. Gilliam, R. Dodge, and L. Fisher. 2008. Patterns in southeast Florida coral reef community composition. Proc. 11th Int. Coral Reef Symp. Ft. Lauderdale 2:811-815.

Schlichter, D. 1982. Nutritional strategies of cnidarians: the absorption, translocation and utilization of dissolved nutrients by Heteroxenia fuscescens. Amer. Zool. 22:659-669.

Schmitz, F., and E. Lorance. 1971. Chemistry of coelenterates. XXI. Lactones from the gorgonian Pterogorgia guadalupensis. J. Org. Chem. 36(5):719-721.

Smith, S. G., D. W. Swanson, M. Chiappone, S. L. Miller, and J. S. Ault. 2011. Probabil- ity sampling of stony coral populations in the Florida Keys. Envir Monitoring Assessment 183:121-138.

Spotte, S., and P. M. Bubucis. 1996. Diversity and abundance of caridean shrimps associated with the slimy sea plume Pseudopterogorgia americana at Pine Cay, Turks and Caicos Islands, British West Indies. Mar. Ecol. Prog. Ser. 133:299-302.

Sprung, J. 2004. Aquarium invertebrates: Caribbean gorgonians: Beauty in motion. Retrieved from Advanced Aquarist: advancedaquarist. com/2004/3/inverts, Accessed 24 Nov. 2014.

Tagliatelia-Scafati, O., U. Deo-Jangra, M. Campbell, M. Roberge, and R. J. Andersen. 2002. Diterpenoids from cultured Erythropodium caribaeorum. Org. Lett. 4(23):4,085-4,088.

Thanner, S., T. McIntosh, and S. Blair. 2006. Development of benthic and fish assemblages on artificial reef materials compared to adjacent natural reef assemblages in Miami-Dade County, Florida. Bull. Mar. Sci. 78:57-70.

Veronique, P. 1987. Annotated checklist of the Gorgonacea from Martinique and Guadeloupe Islands (F.W.I.). Atoll Res. Bull. 303:1-16.

Voss, G. L., and N. A. Voss. 1955. An ecological survey of Soldier Key, Biscayne Bay, Florida. Bull. Mar. Sci. 5(3):203-229. F. M. Bayer, C. R. Robins, M Gomon, and E. T. LaRoe. 1969. The marine ecology of the Biscayne National Monument. A report to the National Park Service by the Institute of Marine and Atmospheric Sciences, University of Miami, Miami, FL. 169 p.

Wahle, C. M. 1980. Detection, pursuit and overgrowth of tropical gorgonians by milleporid hydrocorals: Perseus and Medusa revisited. Science 209:689-691.

1983. The roles of age, size, and injury in sexual reproduction among Jamaican gorgonians. Amer. Zool. 132:961.

1985. Habitat-related patterns of injury and mortality among Jamaican gorgonians. Bull. Mar. Sci. 37:905-927.

Wainwright, S. A., and J. R. Dillon. 1969. On the orientation of sea fans (Genus Gorgonia). Biol. Bull. 136:130-139.

Walker, T. A., and G. D. Bull. 1983. A newly discovered method of reproduction in gorgonian coral. Mar. Ecol. Prog. Ser. 12:137-143.

Wheaton, J. L. 1981. Octocorals (Octocorallia: Gorgonacea). p. 15-23 In Key Largo Cora Reef National Marine Sanctuary deep water resource survey. Jameson S (Ed.), U.S. Dep Commer., NOAA, Off. Coastal Zone Manage., Wash., DC, 144 p.

1987. Observations on the octocoral fauna of southeast Florida's outer slope and fore reef zones. Carib. J. Sci. 23:306-312. and W. C. Jaap. 1988. Corals and other prominent benthic Cnidaria of Looe Key National Marine Sanctuary. Fla. Mar. Res. Publ. 43:1-25.

Wood, E. 2001. Collection of coral reef fish for aquaria: global trade, conservation issues and management strategies. Marine Conservation Society, UK, $80 \mathrm{p}$

Yoshioka, P. M. 1997. Are variations in gorgonian recruitment determined by "presettlement" or "post-settlement" processes? Proc. Eighth Int. Coral Reef Symp. Panama 2:1175-1178

1998. Are large colonies a "key

factor" in the dynamics of gorgonian populations? Rev. Biol. Trop. 46:137-143. and B. B. Yoshioka. 1991. A comparison of the survivorship and growth of shallow-water gorgonian species of Puerto Rico. Mar. Ecol. Prog. Ser. 69:253-260. 